\title{
A Review of Proposed Glen Canyon Dam Interim Operating Criteria
}

by K. LaGory, I. Hlohowskyj, D. Tomasko, J. Hayse, and L. Durham

Environmental Assessment and Information Sciences Division, Argonne National Laboratory, 9700 South Cass Avenue, Argonne, Illinois 60439

April $199 ?$

Work sponsored by United States Department of Energy, Western Area Power Administration

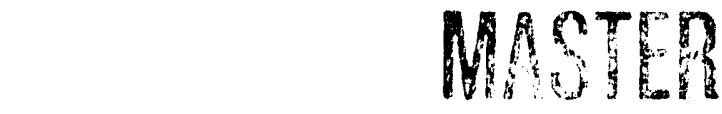




\section{CONTENTS}

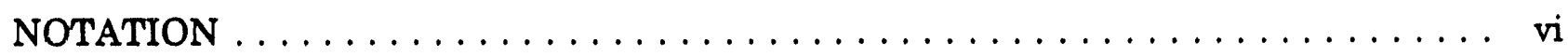

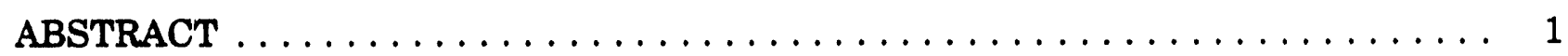

1 INTRODUCTION $\ldots \ldots \ldots \ldots \ldots \ldots \ldots \ldots \ldots \ldots \ldots \ldots \ldots \ldots \ldots \ldots \ldots \ldots \ldots$

2 ENVIRONMENTAL RESOURCES OF THE COLORADO RIVER

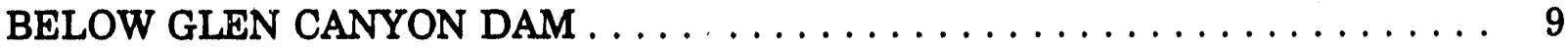

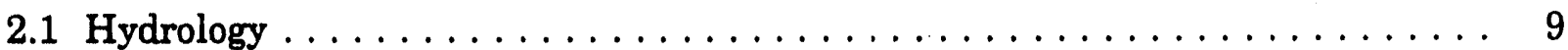

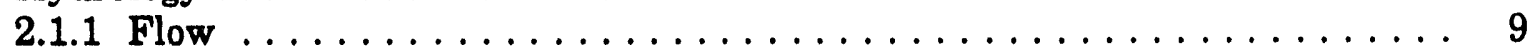

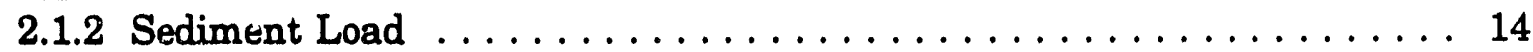

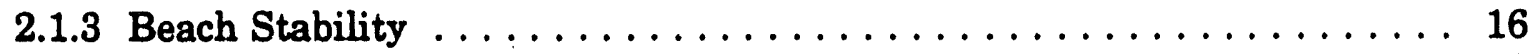

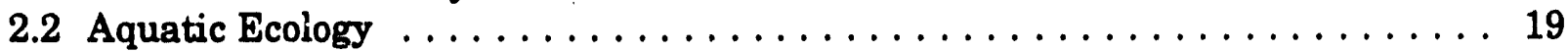

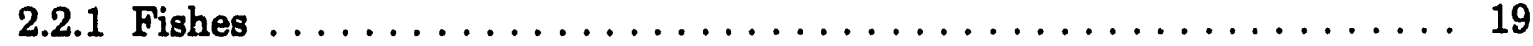

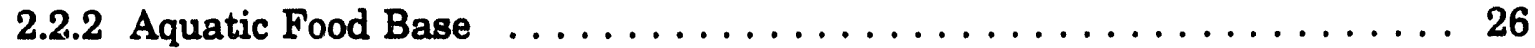

2.2.3 Habitats .............................29

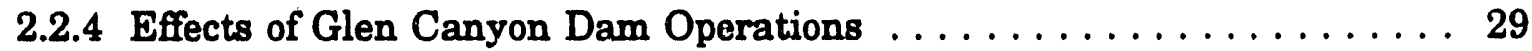

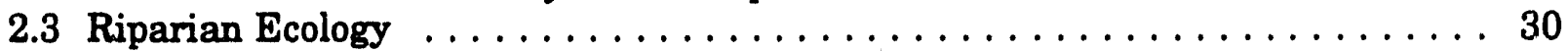

3 EVALUATION OF PROPOSED INTERIM OPERATING CRITERIA . . . . . . . . 34

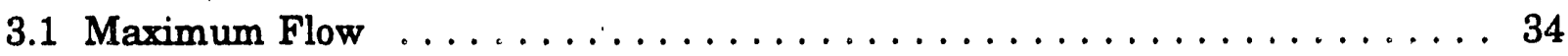

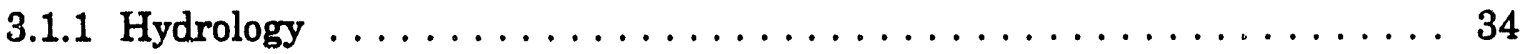

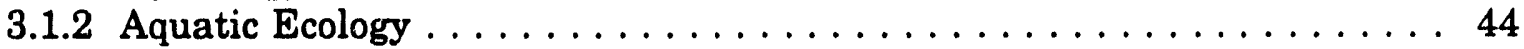

3.1.3 Riparian Ecology . . . . . . . . . . . . . . . . . . . . . . 44

3.2 Minimum Flow $\ldots \ldots \ldots \ldots \ldots \ldots \ldots \ldots \ldots \ldots \ldots \ldots \ldots, \ldots \ldots \ldots$

3.2 .1 Hydrology $\ldots \ldots \ldots \ldots \ldots \ldots \ldots \ldots \ldots \ldots \ldots \ldots \ldots, \ldots \ldots \ldots$

3.2 .2 Aquatic Ecology . . . . . . . . . . . . . . . . . . . . 47

3.2.3 Riparian Ecology . . . . . . . . . . . . . . . . . . . . . 49

3.3 Maximum Daily Fluctuation $\ldots \ldots \ldots \ldots \ldots \ldots \ldots \ldots \ldots \ldots \ldots$

3.3.1 Hydrology . . . . . . . . . . . . . . . . . . . . . 49

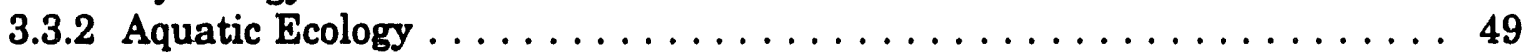

3.3.3 Riparian Ecology . . . . . . . . . . . . . . . . . . . . . 52

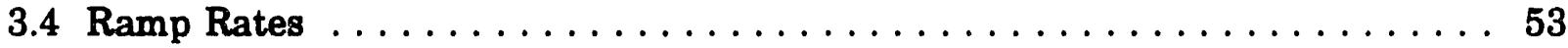

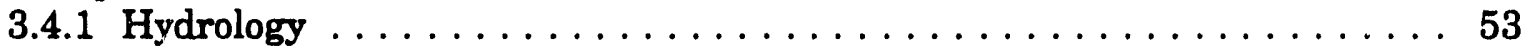

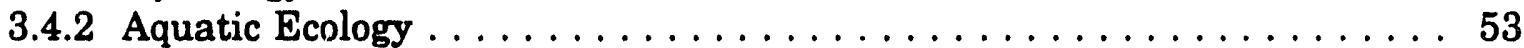

3.4.3 Riparian Ecology $\ldots \ldots \ldots \ldots \ldots \ldots \ldots \ldots \ldots \ldots \ldots \ldots \ldots$

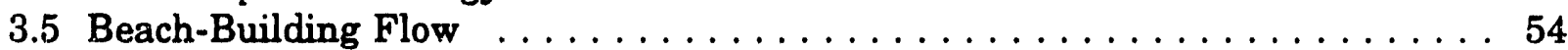

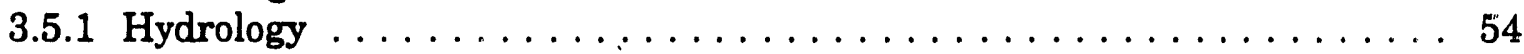

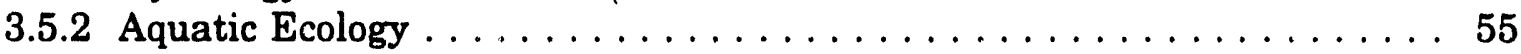

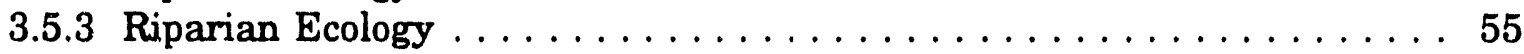

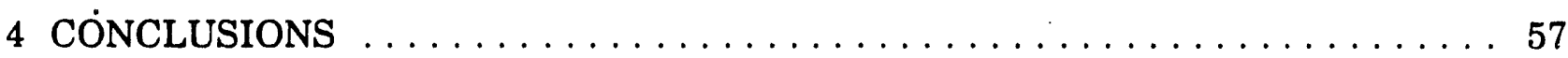

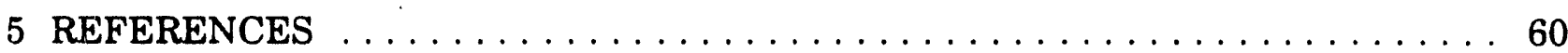




\section{NOTATION}

\begin{tabular}{|c|c|}
\hline acre/mi.yr & acres per mile per year \\
\hline cfs & cubic feet per second \\
\hline $\mathrm{cfs} / \mathrm{d}$ & cubic feet per second per day \\
\hline $\mathrm{cfs} / \mathrm{h}$ & cubic feet per second per hour \\
\hline $\begin{array}{l}\mathrm{d} \\
{ }^{\circ} \mathrm{C}\end{array}$ & $\begin{array}{l}\text { day } \\
\text { degrees Celsius }\end{array}$ \\
\hline E/RM Group & EcologicalResources Managers Group \\
\hline EIS & environmental impact statement \\
\hline $\mathrm{g} / \mathrm{m}^{2}$ & grams per square meter \\
\hline GCES & Glen Canyon Environmental Studies \\
\hline h & hour \\
\hline $\mathrm{m}^{3} / \mathrm{s}$ & cubic meters per second \\
\hline R/S Group & Research/Scientific Group \\
\hline $\mathrm{RM}$ & river mile \\
\hline $\mathbf{s}$ & second \\
\hline STARS & Sediment Transport and River Simulation (computer code) \\
\hline W'STB & Water Science and Technology Board \\
\hline
\end{tabular}




\section{FIGURES}

1 Study Area for the Glen Canyon Dam Environmental Impact Statement and Glen Canyon Environmental Studies .................... 3

2 Historic End-of-Month Water Storage in Lake Powell . . . . . . . . . . . . 10

3 Historic Daily Flows at Lees Ferry $\ldots \ldots \ldots \ldots \ldots \ldots \ldots \ldots \ldots \ldots \ldots$

4 Historic Annual Flows at Lees Ferry . . . . . . . . . . . . . . . . . . 12

5 Discharge from the Glen Canyon Dam d ring Glen Canyon Environmental

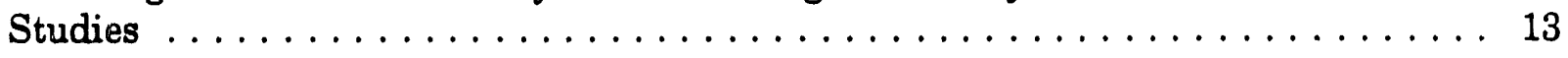

6 Instantaneous Discharge at Lees Ferry Gauge, January 8-11, 1986:

Ty ...al of 1965-1982 Fluctuating Flows . . . . . . . . . . . . . . . 14

7 Sediment Deposits and Sediment-Dependent Resources in the Vicinity of a

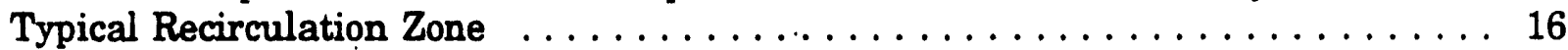

8 Flow Patterns at a Relatively High Discharge in a Typical Recirculation Zone, Showing Primary and Secondary Eddies $\ldots \ldots \ldots \ldots \ldots \ldots \ldots$

9 Distribution of Cladophora, Aquatic Macroinvertebrates, and Trout in the Colorado River Downstream of Glen Canyon Dam

10 Riparian Vegetation Zones in Glen and Grand Canyons before and after Completion of the Glen Canyon Dam ....................... 31

11 Sediment Transported by Various Discharges at the Grand Canyon Gauge,

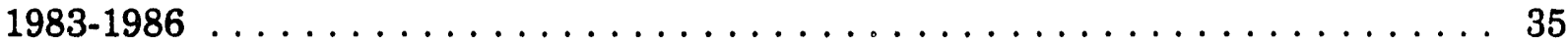

12 Daily Sediment-Load Transport as a Function of Discharge $\ldots \ldots \ldots \ldots \ldots . . \ldots 6$

13 Modified Einstein Sediment-Load Rating Curves for the Colorado River in

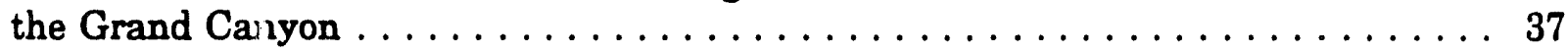

14 Sediment Load as a Function of Discharge at Lees Ferry, Little Colorado River, and Grand Canyon ...................... 37

15 Modified Einstein Sediment-Load Rating Curves for the Colorado River at

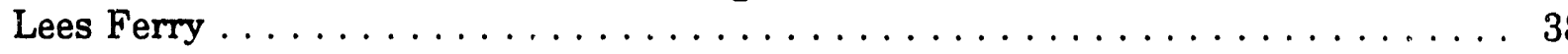

16 Modified Einstein Sediment-Load Rating Curves for the Colorado River above Little Colorado River . . . . . . . . . . . . . . . . . . . . . . . 39

17 Glen Canyon Dam Monthly Releases . . . . . . . . . . . . . . . . 40 


\section{FIGURES (Cont'd)}

18 Hourly Total Releases at Glen Canyon Dam, Flow Duration for Water Year $1982 \ldots \ldots \ldots \ldots \ldots \ldots \ldots \ldots \ldots \ldots \ldots \ldots \ldots \ldots \ldots$

19 Sediment Delivery from the Paria River into the Colorado River, 1948-1975 . . . . 42

20 Relationship between Flow and Availability of Backwater Habitat at Three Locations in the Green River, Utah ...

21 Instantaneous Flow and Rates of Change in Flow in the Colorado River during Trout-Stranding Studies

\section{TABLES}

1 Historic and Proposed Interim Operating Criteria for Glen Canyon Dam . . . . . 5

2 Target Resources to Be Protected by the Three Proposed Interim

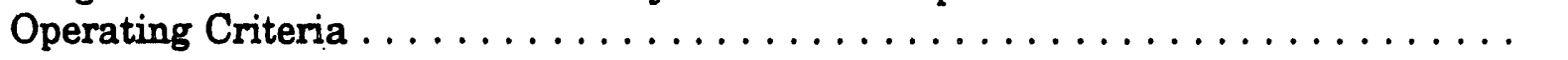

3 Fish Species of the Lower Colorado River between Glen Canyor Dam and Lake Mead 


\title{
A REVIEW OF PROPOSED GLEN CANYON DAM INTERIM OPERATING CRITERIA
}

by

\author{
K. LaGory, I. Hlohowskyj, D. Tomasko, J. Hayse, and L. Durham
}

\begin{abstract}
Three sets of interim operating criteria for Glen Canyon Dam on the Colorado River have been proposed for the period of November 1, 1991, to the completion of the record of decision for the Glen Canyon Dam environmental impact statement (about 1993). These criteria set specific limits on dam releases, including maximum and minimum flows, up-ramp and down-ramp rates, and maximum daily fluctuation. Under the proposed interim criteria, all of these parameters would be reduced relative to historical operating criteria to protect downstream natural resources, including sediment deposits, threatened and erdangered fishes, trout, the aquatic food base, and riparian plant communities. The scientific bases of the three sets of proposed operating criteria are evaluated in the present report: (1) criteria proposed by the Research/Scientific Group, associated with the Glen Canyon Environmental Studies (GCES); (2) criteria proposed by the Ecological/Resource Managers Group, composed of state and federal officials charged with managing downstream resources; and (3) test criteria imposed from July 31, 1991, to November 1, 1991. Data from Phase I of the GCES and other sources established that the targeted natural resources are affected by dam operations, but the specific interim criteria chosen were not supported by any existing studies. In addition, it is unlikely that irreversible changes to any of the resources would occur over the interim period if historical operating criteria remained in place. It is likely that adoption of any of the sets of proposed interim operating criteria would reduce the levels of sediment transport and erosion below Glen Canyon Dam; however, these interim criteria could result in some adverse effects, including the accumulation of debris at tributary mouths, a shift of new high-water-zone vegetation into more flood-prone areas, and further declines in vegetation in the old high water zone.
\end{abstract}

\section{INTRODUCTION}

On July 27, 1989, the Secretary of the Interior directed that an environmental impact statement (EIS) be prepared on the effects of Glen Canyon Dam operations on downstr am environmental and ecological resources along the Colorado River. An EIS was 
deemed necessary for two reasons: (1) Glen Canyon Dam was constructed before the enactment of the National Environmental Policy Act and, therefore, an EIS had never been prepared for the facility and (2) public concern had increased regarding the impacts of dam operations on downstream resources, particularly within Grand Canyon National Park. The study area for the Glen Canyon Dam EIS includes reaches of the Colorado River approximately 15 and 277 miles long in the Glen Canyon National Recreational Area and Grand Canyon National Park, respectively (Figure 1). A draft of the EIS is expected to be released for public comment in 1993.

A series of investigations, called the Glen Canyon Environmental Studies (GCES), was initiated by the Department of the Interior in December 1982 to investigate the impacts of current and alternative dam operations on downstream natural resources. The initial phase of the GCES included more than 30 technical studies by a multiagency group of researchers. Specific agencies cooperating in the studies included the Bureau of Reclamation, the National Park Service, and the U.S. Fish and Wildlife Service. Cooperation and contributions to the studies also came from the Arizona Department of Game and Fish, the U.S. Geological Survey, private consultants, universities, and private and commercial river runners and guides.

The initial objective of the GCES was to investigate the effects of dam operations on downstream resources. Because of unanticipated flood releases from Glen Canyon Dam from 1983 to 1986, staged releases designed to evaluate threshold effects (e.g., sediment transport) could not be implemented. The objectives of the studies were therefore modified (National Academy of Sciences 1987). A portion of the modified studies included determining if current dam operations adversely affected the existing riverine environmental and recreational resources of Glen and Grand canyons and if the dam could be operated in ways that would protect or enhance the resources and, at the same time, stay within the constraints of existing legislation that specify the volume of water to be released.

Releases from Glen Canyon Dam have to satisfy Section 602(a) of the Colorado River Storage Project Act, which requires delivery of 75 million acre-feet of water during every 10-year period to the lower basin states (Arizona, Nevada, and California) (Weatherford and Babbitt 1986). In addition, 7.5 million acre-feet of water must be delivered during every 10-year period to the lower basin states under the requirements of the subsequent Mexican Water Treaty (National Academy of Sciences 1987). After subtracting an average 0.2 million acre-feet of water from the northern basin states that is supplied by the Paria River every 10 years, 82.3 million acre-feet of water must be released from the dam during every 10-year period.

The GCES were neither intended nor designed to lead directly to changes in dam operations. Phase I of the GCES was completed and a finil report issued in January 1988 (U.S. Department of the Interior 1988). In response to a request from the Department of the Interior, the Water Science and Technology Board (WSTB) of the National Research Council agreed to review the draft GCES Phase I report and to provide advice on alternative 


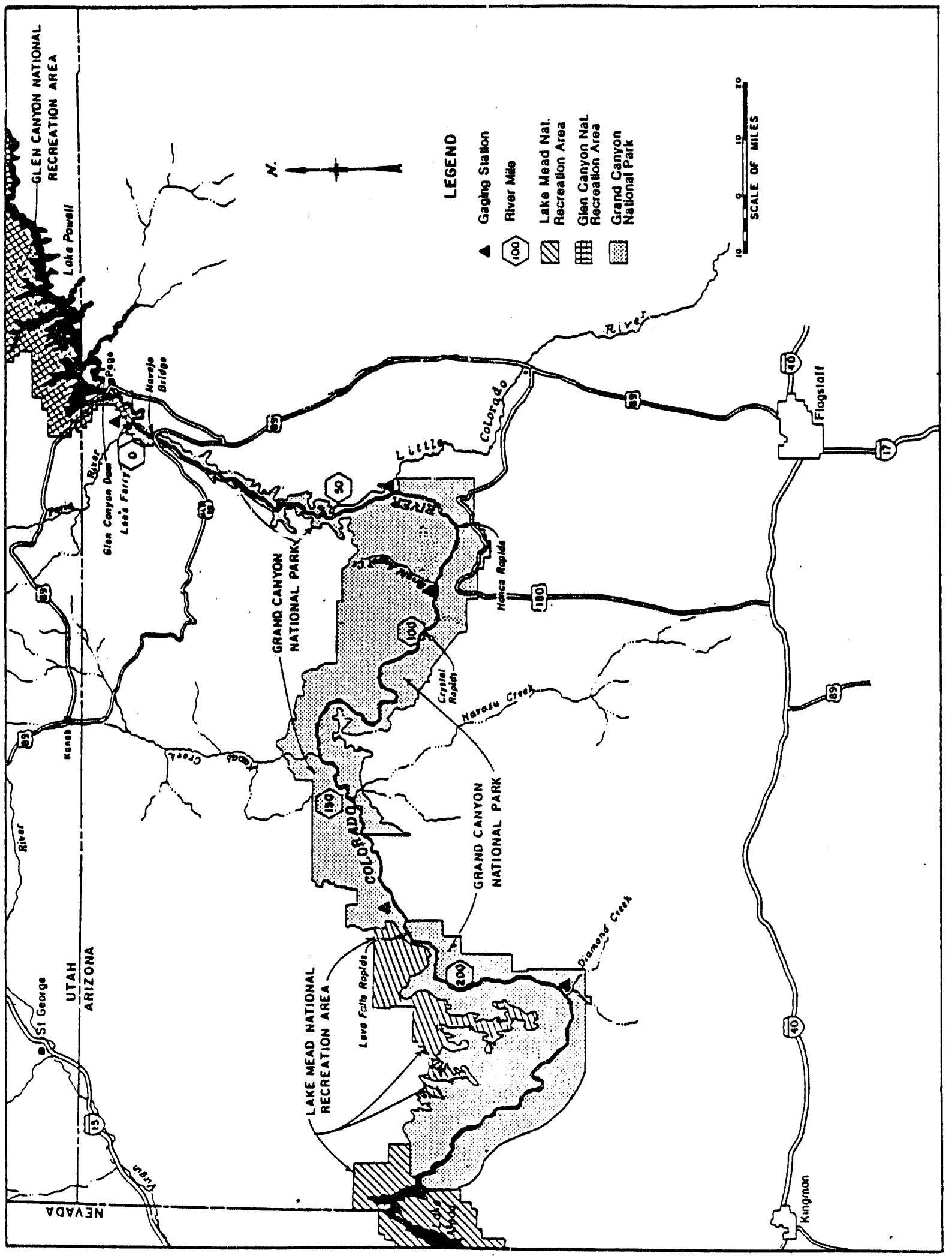

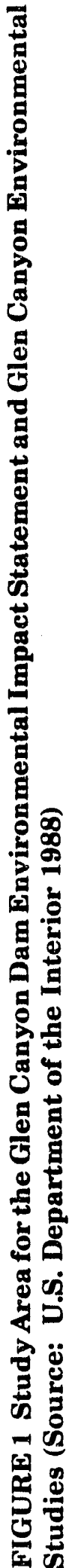


operational schemes for the dam. The WSTB completed its review and presented its conclusions in 1987 (National Academy of Sciences 1987). A major finding of the WSTB was that the Phase I studies were inconclusive and additional studies were recommended.

Phase II of the GCES was initiated in 1988 to address some of the shortfalls of the Phase I studies. The schedule of the Phase II work was expedited with the release of "research" river flows from June 1990 through July 1991. Specific flows were adopted to test hypotheses regarding the relationships between dam operations and environmental variables. Within 90 days of completion of the GCES research flows, the Secretary of the Interior committed to implementing "interim" flows that will be in effect from November 1, 1991, until the EIS is completed, a record of decision has been issued, and a long-range plan finished (about 1993). Results of the Phase II studies were not available at the time this document was prepared.

The purpose of this report is to perform a critical review of the three sets of interim operating criteria proposed to protect natural resources downstream of Glen Canyon Dam (Table 1). The proposed operating criteria include flows (1) suggested by the Research/ Scientific $(R / S)$ Group, a group of scientists associated with the GCES; (2) suggested by the Ecological/Resource Managers (E/RM) Group, a group composed of state and federal officials charged with managing downstream environmental resources; and (3) inferred from test criteria implemented between July 31, 1991, and November 1, 1991. As presented in Table 1, the differences between the sets of proposed operating criteria are slight and occur primarily in the suggested values for maximum daily flow changes and ramp rates.

The operating criteria proposed by the R/S Group were developed to protect the abiotic (sediment) and biotic (aquatic and riparian) attributes of the Colorado River in Glen and Grand canyons until the EIS record of decision is issued (Table 2). The R/S operating criteria were based on information from Phase I and preliminary results from Phase II of the GCES. Recreational resources were not explicitly considered by the R/S Group during development of interim operating criteria.

The E/RM Group recommended interinz operating criteria that are nearly identical to those proposed by the R/S Group (see Table 1), except that the minimum release recommended by the E/RM Group is 8,000 cubic feet per second (cfs) at all times. As with the R/S criteria, the interim operating criteria proposed by the E/RM Group have the objective of protecting downstream riverine resources (Table 2). The E/RM low-flow criterion also is designed to protect an important cultural/historical resource, the Charles S. Spenser steamboat, which is located at Lees Ferry. Below $8,000 \mathrm{cfs}$, the steamboat is exposed to air, thus accelerating oxidation and degradation of the boiler and remaining superstructure (U.S. Department of the Interior 1991a). 


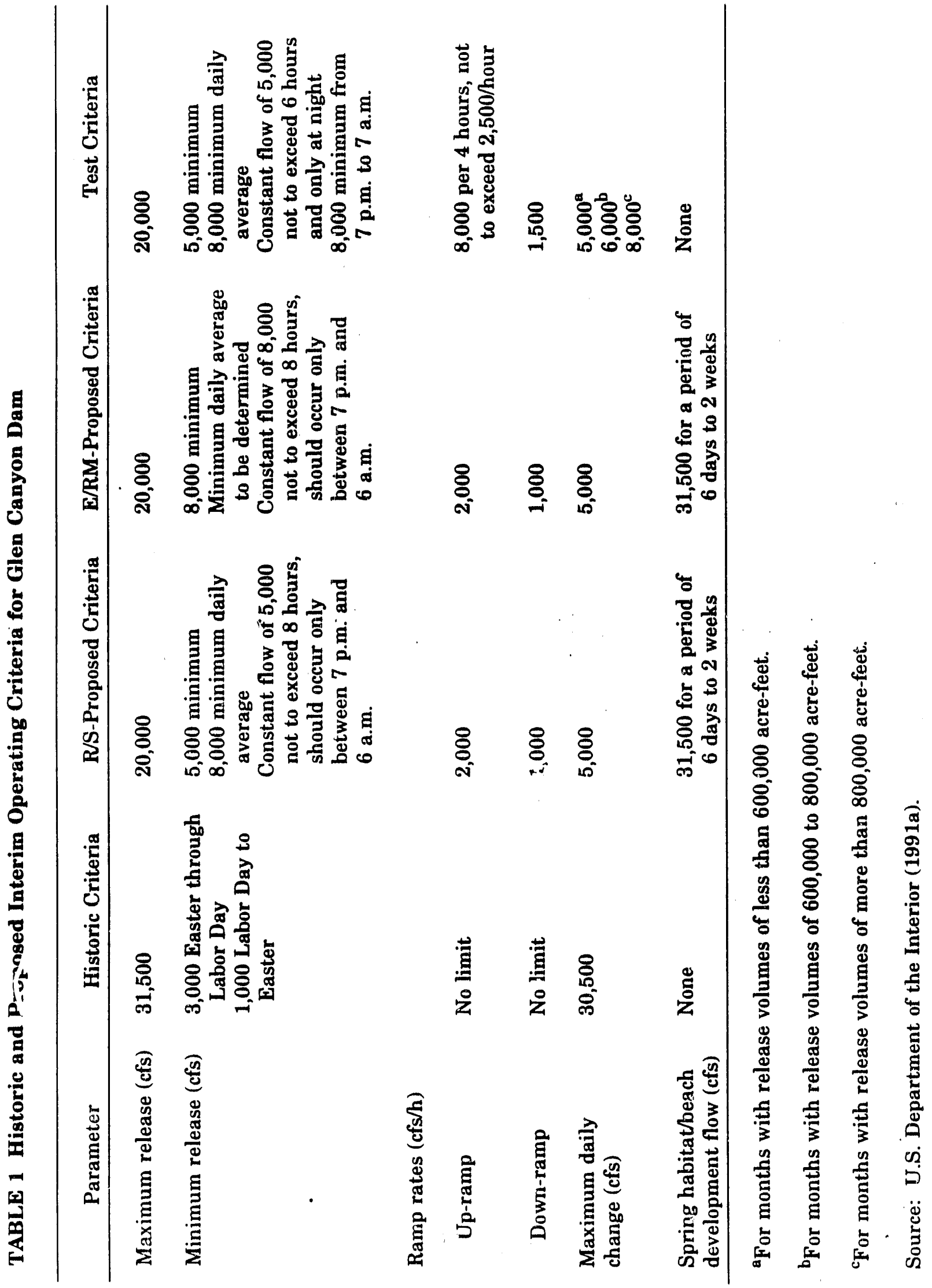




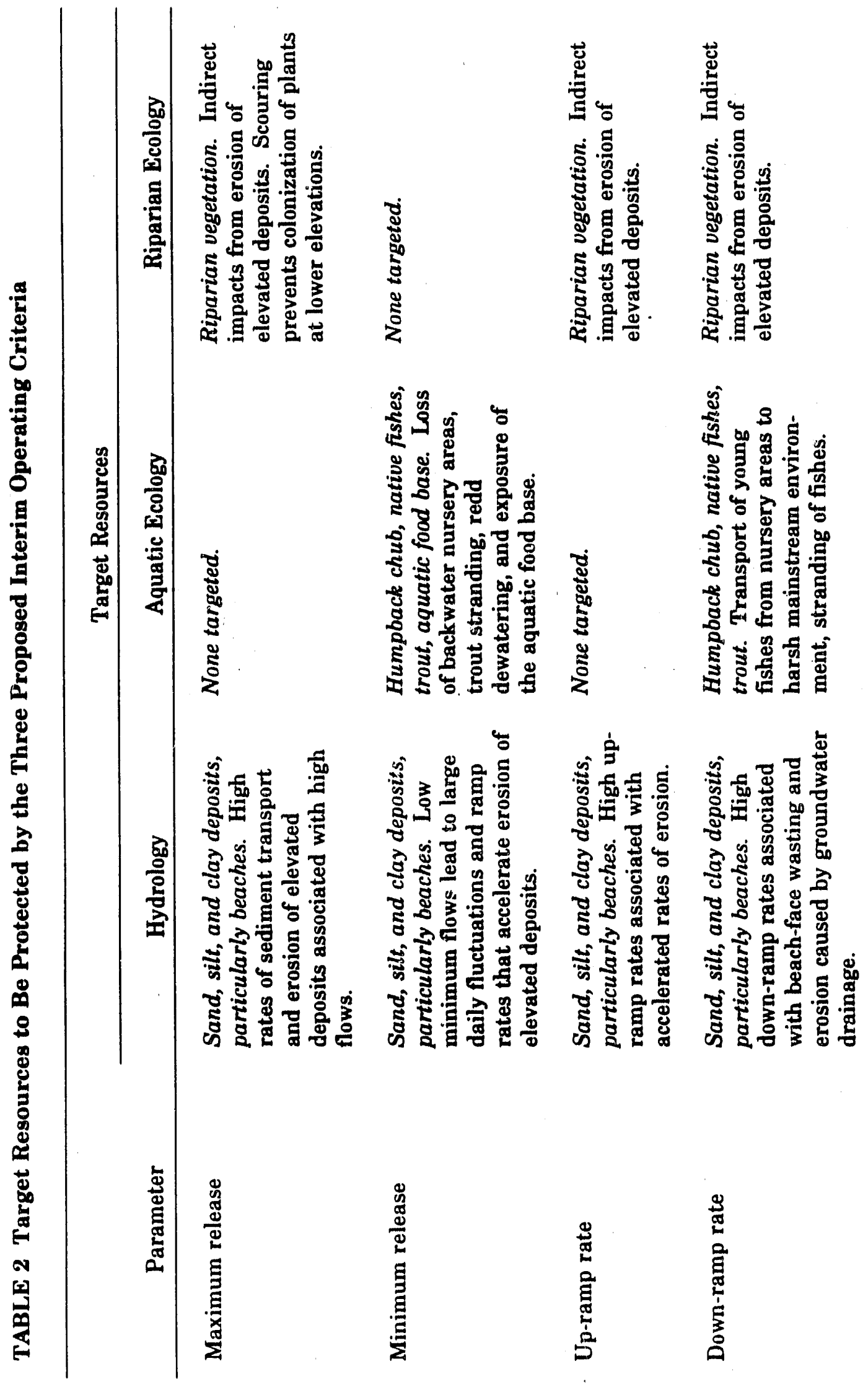




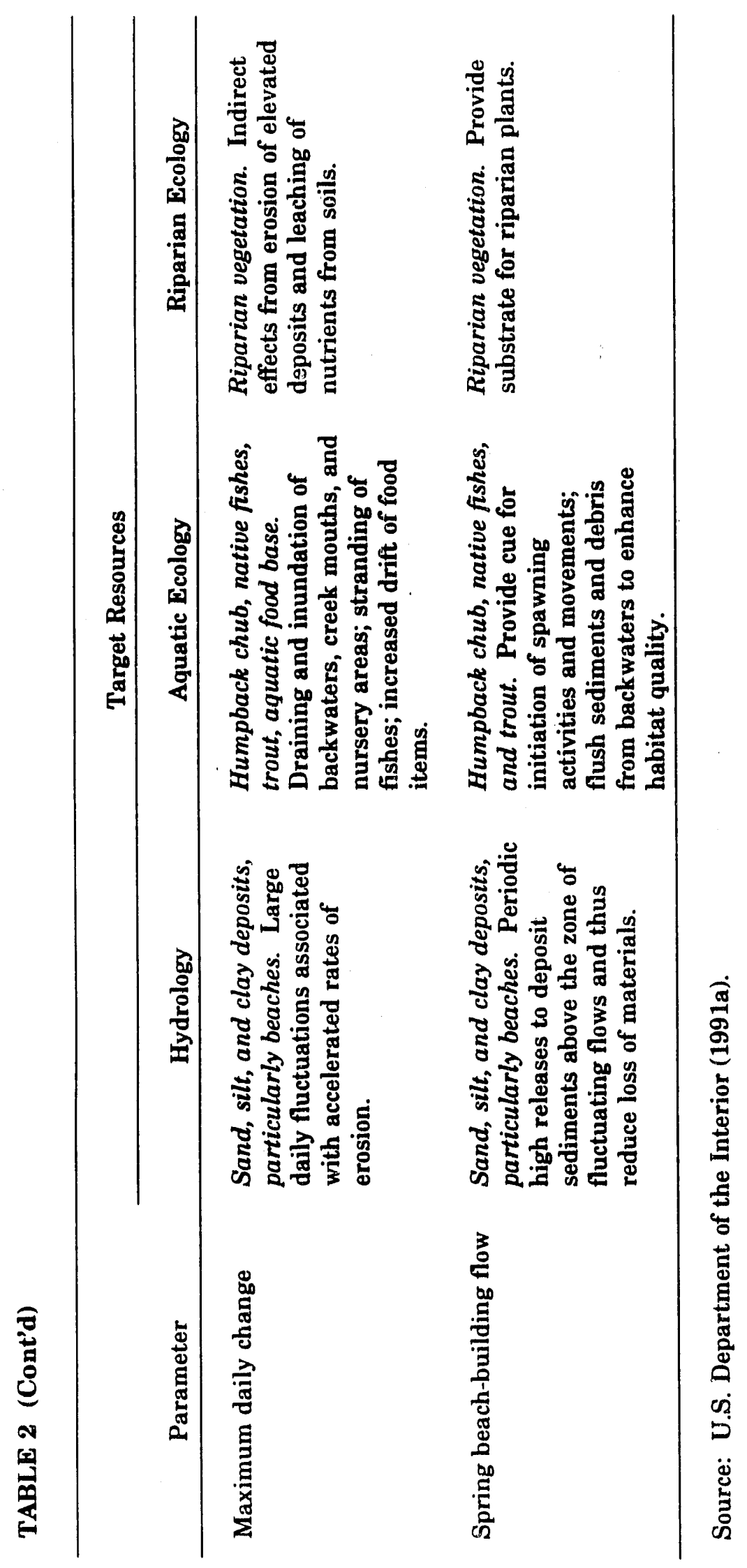


The operating criteria developed for the test flows are similar to the other proposed operating criteria, except the up- and down-ramp rates are somewhat higher, and during medium and high flow months, the maximurn daily change is somewhat higher (Table 1). The Commissioner of Reclamation announced the test flows on July 30, 1991. These flows were to be in effect from July 31,1991, to November 1, 1991. This testing period was designed to allow time to evaluate data from the research flows more fully and to carny out National Environmental Policy Act compliance for implementation of interim operating criteria (U.S. Department of the Interior 1991a).

This report examines the scientific bases of these three proposals. The evaluation focuses on information presented in the following documents: Glen Canyon Environmental St udies Final Report (U.S. Department of the Interior 1988), River and Dam Management: A Review of the Bureau of Reclamation's Glen Canyon Environmental Stidies (National Academy of Sciences 1987), and Glen Canyon Dam Interim Operating Criteria Supporting Document (U.S. Department of the Interior 1991a). Specific areas of concern are addressed by the following questions:

- Are the natural resources that are the focus of the proposed interim operating criteria those that are potentially affected by dam operations, and would those resourses be irreversibly affected by dam operations in the short term?

- Are the methodologies used to develop the proposed interim operating criteria objective and scientifically based, anc's are the available data unambiguous and sufficient to recommend interim operating criteria?

- Are the proposed interim operating criteria supportable on the basis of available data?

- Are there alternatives to the proposed operating criteria that would be as protective of the environmental resources as the proposed interim operating criteria, on the basis of available GCES information?

A number of basic topics related to hydrology and to aquatic and riparian ecology are discussed in this report to address these questions. The hydrologic topics include the effects of Glen Canyon Dam operations on maximum and minimum dorrnstream flows in the Colorado River, flow fluctuations, downstream sediment transport, beach erosion and aggradation, and beach stability. 'Topics in aquatic ecology include endangered and native fishes, trout, aquatic food base and habitat, and the effects of dam operations on these resources. Topics in riparian ecology include pre- and post-dam riparian communities and the effects of dam operations and floods on these communities. After these basic topics are discussed, the proposed operating criteria are evaluated in the context of their scientific basis and their ability to protect the designated natural resources in the Colorado River below Glen Canyon Dam. 


\section{ENVIRONMENTAL RESOURCES OF THE COLORADO RIVER BELOW GLEN CANYON DAM}

\subsection{HYDROLOGY}

\subsubsection{Flow}

Before Glen Canyon Dam was constructed (pre-dam), flow in the Colorado River in the study area (Figure 1) was unregulated; annual peak flows averaged $93,400 \mathrm{cfs}$ between 1921 and 1962, and a maximum flow of 300,000 cfs has been postulated for July 7, 1884 (U.S. Department of the Interior 1988). The lowest recorded flow (700 cfs) occurred in December 1924 (Carothers and Brown 1991). The average annual minimum flow was about 4,000 cfs. The average yearly flow in the Colorado River at Lees Ferry for the period of 1922 through 1990 was about 11.3 million acre-feet. Although the range of flows in the river varied widely on annual and seasonal bases, daily fluctuations and hourly changes in flow before dam operations were small except during floods.

With the completion of Glen Canyon Dam in 1963 (post-dam), flow in the study area between Lake Powell and Lake Mead became regulated and ranged from about 1,000 to 31,500 cfs between 1963 and 1980, when the Lake Powall reservoir filled (Figure 2) (U.S. Department of the Interior 1990). During the first two years of the filling period, only 5 million acre-feet was allowed to flow from the dam in order to build ap Lake Powell water levels to an elevation suitable for power generation. This low release depleted water levels downstream in Lake Mead to the point that Hoover Dam could not effectively produce power. To compensate for this loss of water, Glen Canyon Dam released 11 million acre-feet of water in 1965 (Carothers and Brown 1991). On June 15, 1965, an instantaneous peak discharge of $60,200 \mathrm{cfs}$ was reached (Schmidt 1987). This discharge scoured much of the river reach between the dam and Lees Ferry.

When Lake Powell filled in 1980 , excess water storage capacity was eliminated, and spring flood releases (discharges greater than the maximum power-plant release of $31,500 \mathrm{cfs}$ ) became more comrion (Figure 3) (U.S. Department of the Interior 1990). From about June 1983 to July 1986, higher than normal peak flows occurred because of wet weather (Figure 4) (U.S. Department of the Interior 1990). A peak flow of about 93,000 cfs occurred in June 1983. Because of the unusually large quantity of water released, flows during these years tended to be steady, that is, fluctuations greater than $10,000 \mathrm{cfs}$ per day occurred less than $31 \%$ of the time (U.S. Department of the Interior 1988), compared with $78 \%$ of the time during the reservoir-filling period of 1963 through 1980 . These high, relatively steady flow conditions started about one year before the GCES were initiated in 1982 and continued through near the end of the project (Figure 5). Therefore, unusual flow conditions predominated in the study area throughout most of the study period. Most of the flows during the study were at the high end of power-plant releases, and low to medium flows were uncommon; flows of less than 10,000 cfs occurred on less than $8 \%$ of the days from 1983 through 1986 (U.S. Department of the Interior 1988). 


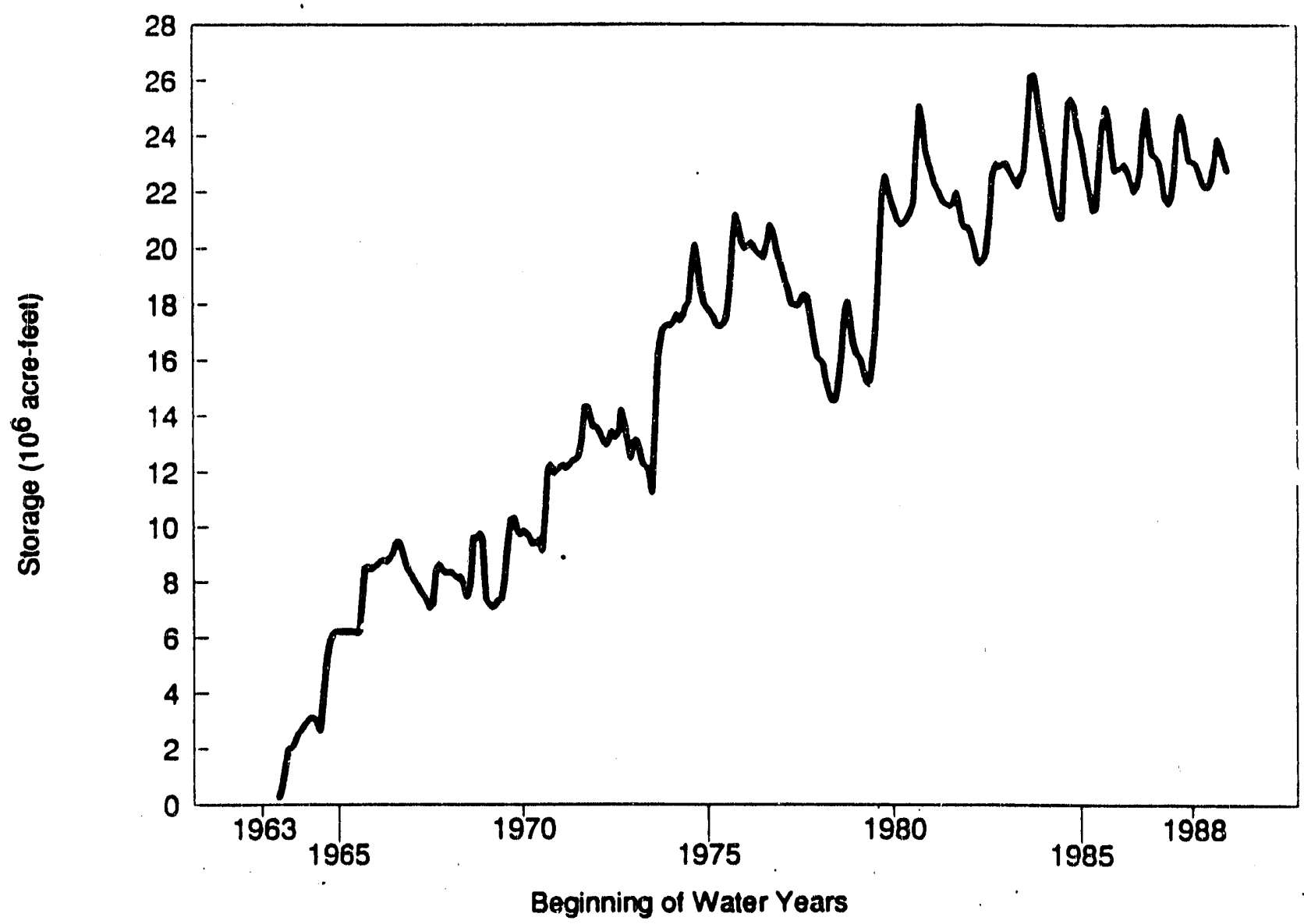

FIGURE 2 Historic End-of-Month Water Storage in Lake Powell (Source: U.S. Department of the Interior 1990)

From October 1985 through January 1986, strongly fluctuating flows were released to provide research information; the monthly average instantaneous low discharge was $1,790 \mathrm{cfs}$, and the monthly average instantaneous high discharge was $24,390 \mathrm{cfs}$ (Schmidt 1987). The average daily ranges of fluctuations were $15,100,14,000$, and $18,500 \mathrm{cfs}$ for the months of October, November, and December 1985, respectively. Although these values were typical of normal dam operations, they were unprecedented in that they immediately followed a period of very high, steady water releases (Schmidt 1987).

When Glen Canyon Dam is operated to produce peaking power, fluctuating water releases are used. As indicated in Figure 6, the range of daily flows has pronounced peaks and troughs that correspond to the cycle of power demand. In general, the peak releases occur in the morning and evening, with the evening peak higher than the morning peak. The greatest daily flow fluctuations typically occur during August. For the period 1966 to 1989, the average daily change of flow was $14,900 \mathrm{cfs}$ (U.S. Department of the Interior 1991b). Between 1965 and 1990, the maximum daily ramp rates (the rate of change in volumetric 


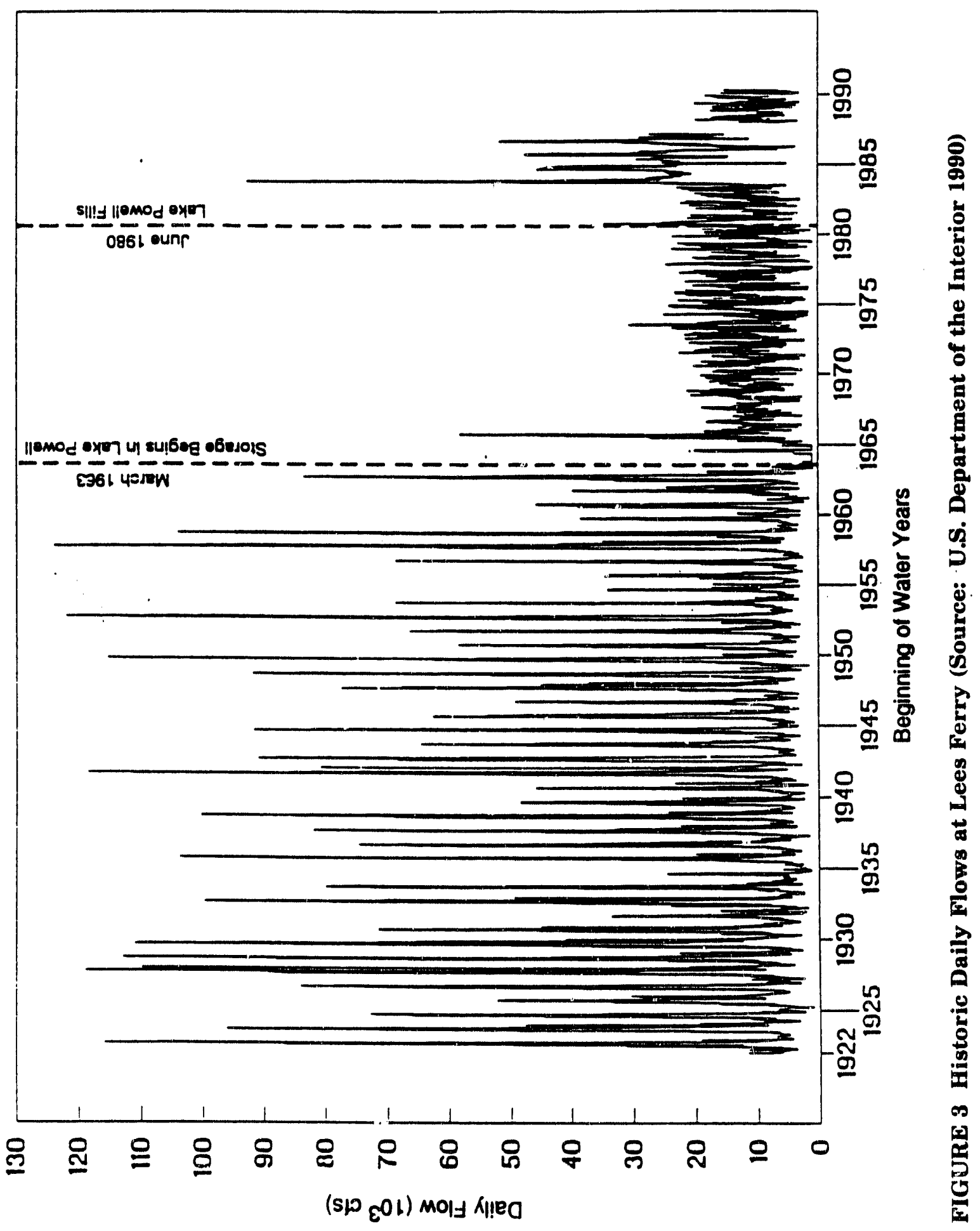




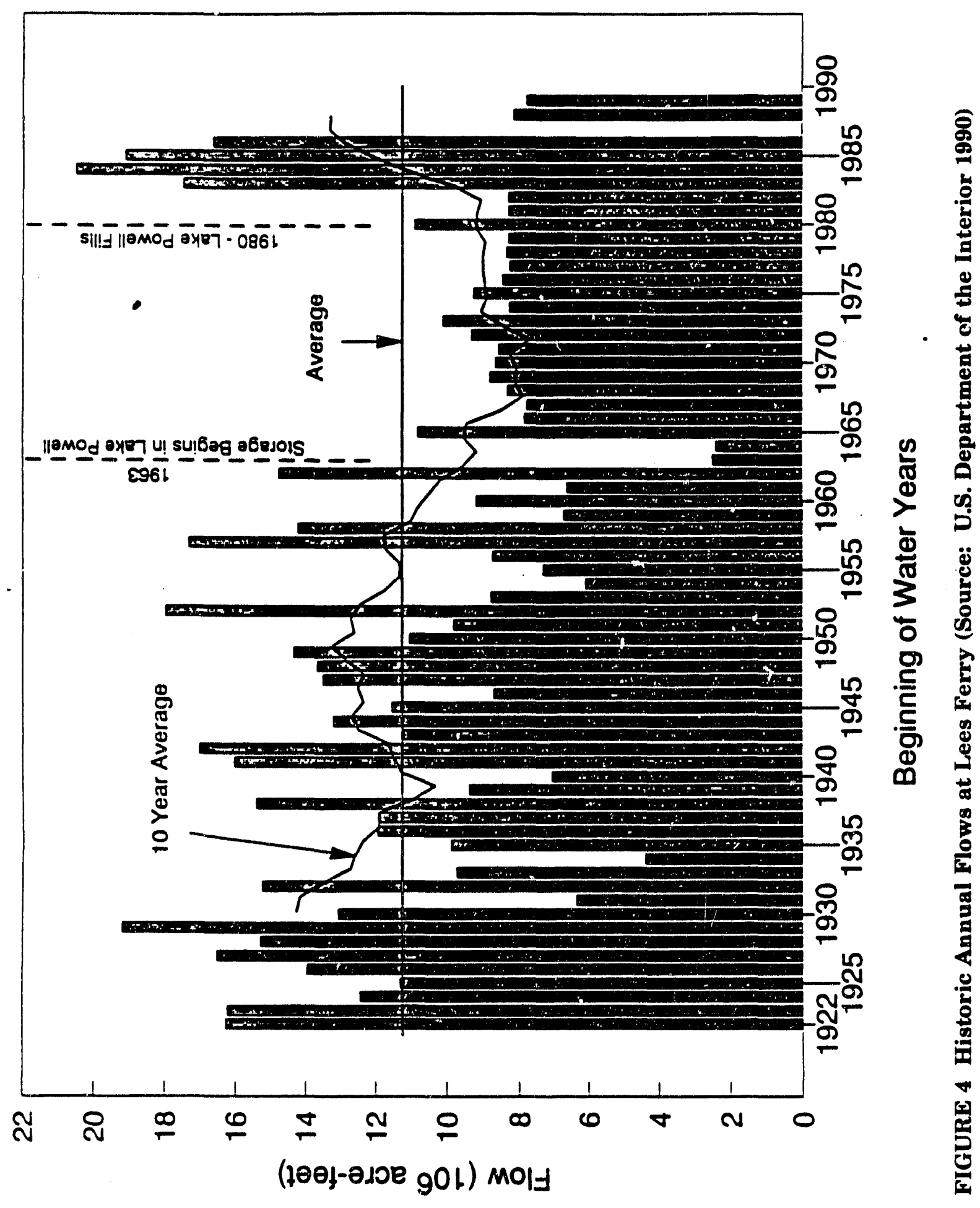



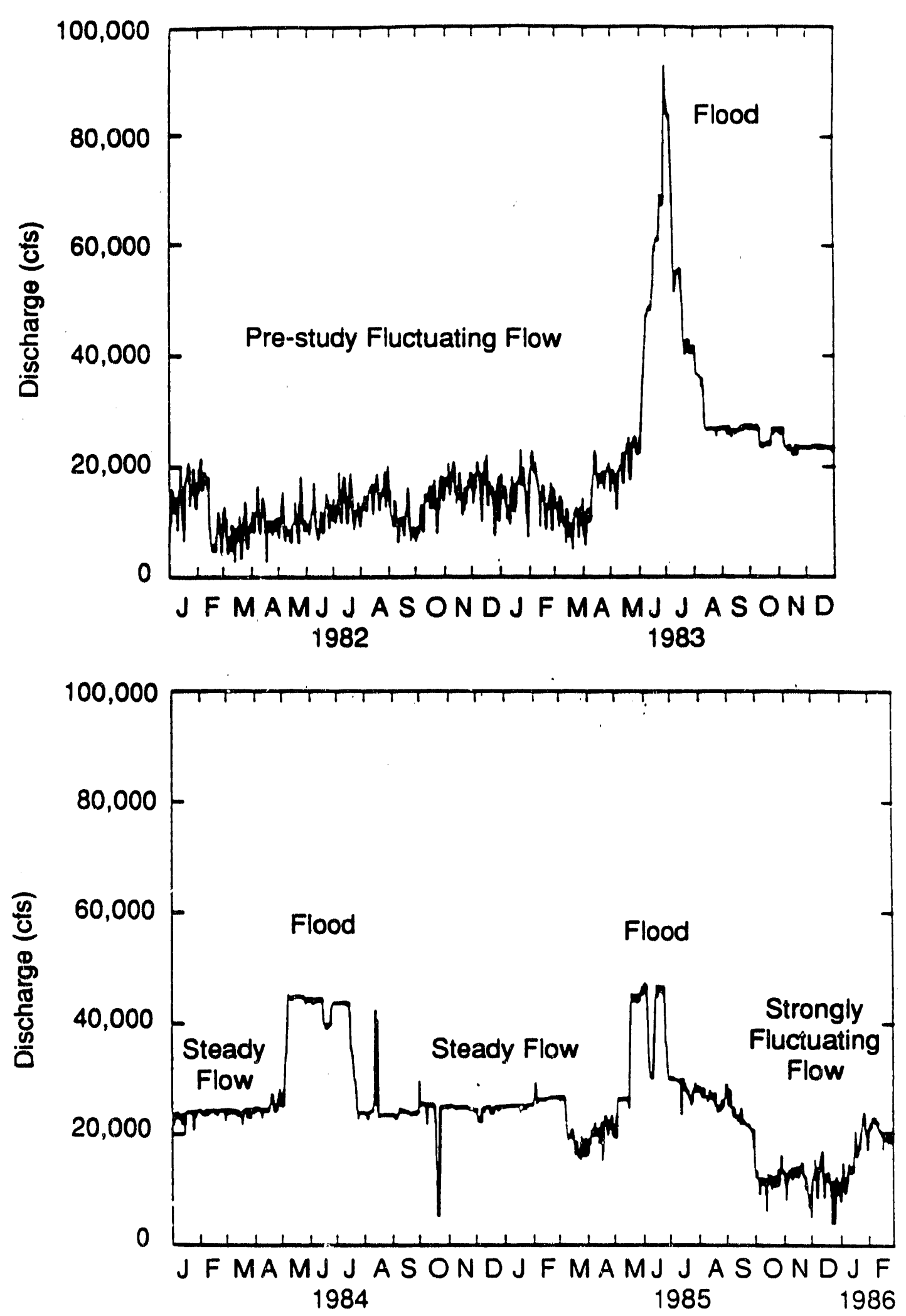

FIGURE 5 Discharge from the Glen Canyon Dam during Glen Canyon

Environmental Studies (Sourre: U.S. Department of the Interior 1988) 


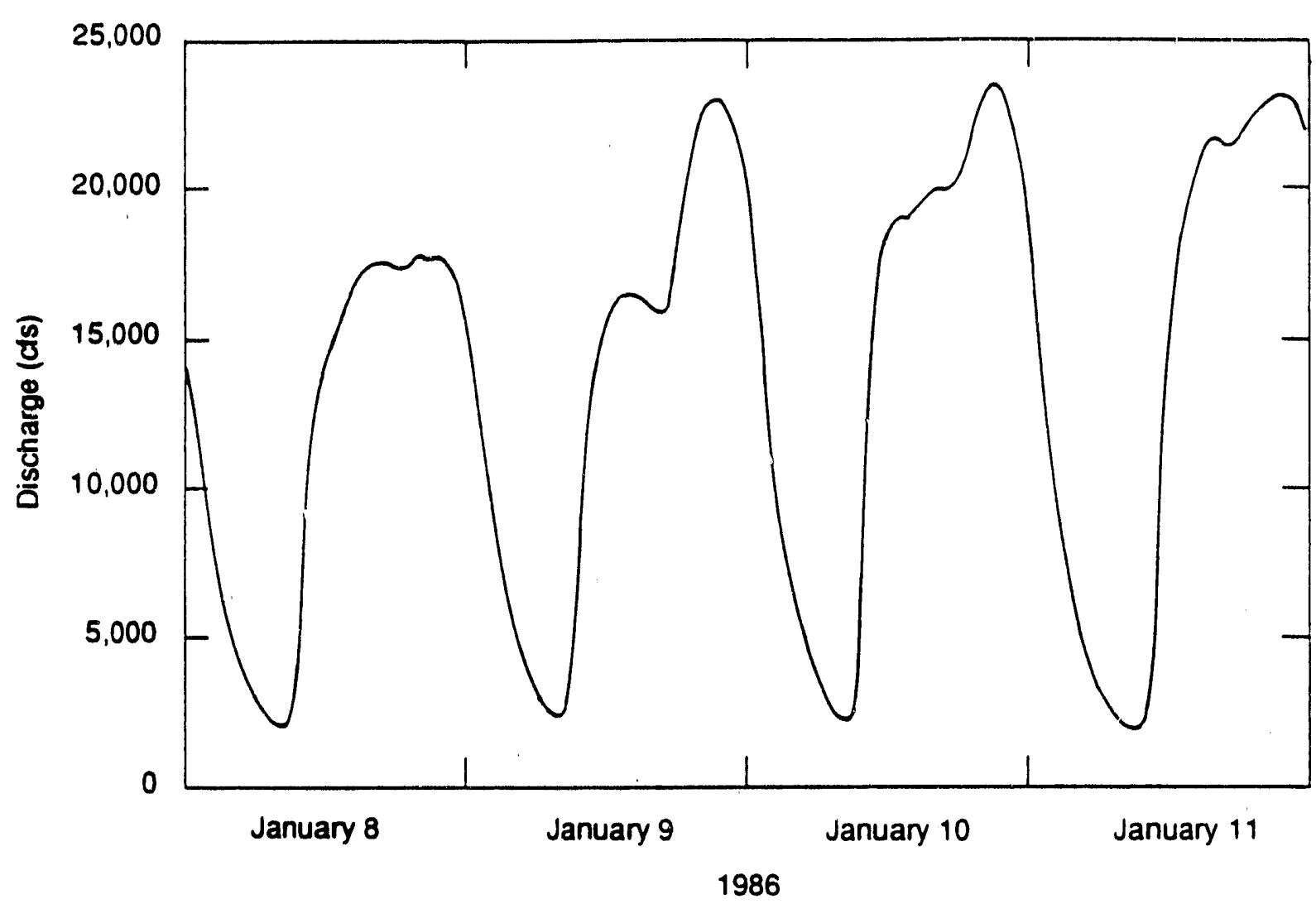

FIGURE 6 Instantaneous Discharge at Lees Ferry Gauge, January 8-11, 1986: Typical of 1965-1982 Fluctuating Flows (Source: Schmidt and Graf 1990)

flow per unit time) exceeded $5,000 \mathrm{cfs} / \mathrm{h}$ (one-hour duration) about $50 \%$ of the time and exceeded $3,000 \mathrm{cfs} / \mathrm{h}$ (three-hour duration) about $50 \%$ of the time (U.S. Department of the Interior 1991b).

Ramp rates are also a function of yearly runoff (McQuivey 1991a). For a normal runoff year (1980), the mean ramp rate was $2,445 \mathrm{cfs} / \mathrm{h}$, and a ramp rate of $19,000 \mathrm{cfs} / \mathrm{h}$ was exceeded five times. For a low runoff year (1989), the mean ramp rate fell to $2,291 \mathrm{cfs} / \mathrm{h}$, and ramp rates never exceeded $19,000 \mathrm{cfs} / \mathrm{h}$. For a high runoff year (1986), the mean ramp rate was lower $(1,823 \mathrm{cfs} / \mathrm{h})$, and the $19,000 \mathrm{cfs} / \mathrm{h}$ rate was exceeded three times.

\subsubsection{Sediment Load}

Before Glen Canyon Dam was constructed, sediment transport through the Grand Canyon averaged about 140 million tons/year and had a range of 50-500 million tons/year (National Academy of Sciences 1987). With the completion of the dam, sediment from sources upstream of the impoundment became trapped in Lake Powell; sediment below the dam was delivered to the Colorado River primarily by three major tributaries below Lees Ferry: the Little Colorado River, the Paria River, and Kanab Creek (Figure 1). Together, these three 
tributaries are estimated to supply an average of about 2.9 million tons of sediment each year (Randle and Pemberton 1987); however, their sediment load can vary by as much as an order of magnitude (U.S. Department of the Interior 1988). The long-term average annual sediment load from all tributaries between Glen Canyon Dam and Lake Mead is estimated to be 3.7 million tons/year (Randle and Pemberton 1988).

Dam-induced reductions in sediment load are greatest between the dam and Lees Ferry, a reach with no major tributaries. The sediment load in this reach was estimated to be 0.4 million tons/year in 1982 and 1986, a decrease of about $99.5 \%$ from pre-dam conditions (U.S. Department of the Interior 1988). Downstream of Lees Ferry, sediment is delivered in erratic, hard-to-predict patterns from the Little Colorado River, the Paria River, Kanab Creek, and an additional 310 ungauged tributaries (Webb et al. 1987) that deliver sediment to the main channel through a combination of norrial channel inflow and debris flow. Debris flows consist of water-based slurries of poorly sorted clay to boulder-size particles with a water content of $15-40 \%$ (Howard and Dolan 1981; Webb 1988). Debris flows are estimated to have reached the Colorado River about every 200 years during the past 1,500 years and every 20-30 years since 1916 (Webb 1988). Randle and Pemberton (1987) estimated that debris lows from tributaries provide 0.7 million tons/year of sediment to the Colorado River system. Surface runoff, mainstream rock slides, and eolian transport are additional sources of sediment to the river.

During Phase I of the GCES, a mainstream sediment transport model was developed, calibrated, and used to predict the effects on sediment transport of various operational scenarios for the dam (Randle and Pemberton 1988; Orvis and Randle 1988; Pemberton 1988). The one-dimensional, steady-state Sediment Transport and River Simulation (STARS) computer model included a stream-tube feature to model transport characteristics for critical to subcritical flow conditions (Orvis and Randle 1988). For calibration purposes and for defining sediment-load rating curves, sediment data were collected at five sampling locations in the 225-mile rearh of the Colorado River below Glen Canyon Dam (Pemberton 1988). Sampling was performed from June 1983 to December 1983 (high, steady flows) and October 1985 to January 1986 (strongly fluctuating flows) (Pemberton 1988). The Modified Einstein Method (Colby and Hembree 1955) was used to compute the total sediment in transport at a measurement location from the discharge values, suspended load, and samples of the bed material. This methodology is a standard technique used to develop sediment-load rating curves.

The sediment transport calculations performed for Phase I of the GCES represent state-of-the-art modeling techniques. The results of the calculations are, however, uncertain because of the inherent complexity of the sediment transport processes occurring in the Colorado River (e.g., the variability of debris flow occurrence and the absence of a general model for predicting the magnitude and frequency of these flows), the transient nature of the transport processes, the difficulties associated with obtaining precise input data required for the modeling, the dynamic (nonequilibrium) nature of the affected reach in the study area, and the lack of a numerical model capable of accurately simulating all of the important physical processes taking place. Without extensive additional field work and analyses, such as the work scheduled for Phase II of the GCES, the Phase I results should be considered tentative. 


\subsubsection{Beach Stability}

The Colorado River has a pool-and-rapid form throughout most of the Grand Canyon (Burkham 1988). The rapids are typically located at the mouth of a tributary stream and are generally part of an alluvial fan. Pools are either sediment sinks or sources; bottoms of the pools fill with sediment during low flows or are scoured during periods of high flows. Separation and reattachment sand deposits (Figure 7) associated with the debris fans at the mouth of the tributaries are frequently used as campsites and are substrates for riparian vegetation (Schmidt and Graf 1988). Separation deposits, located on the downstream surface of debris fans, are typically higher and steeper than other deposits. Reattachment deposits, located at the downstream end of recirculation zones, are broader and lower in elevation than separation deposits (Figure 7). Inundated low-elevation areas between separation and reattachment deposits (backwaters) may become low-velocity, warmwater habitats under some flow conditions ( Figure 8). Additional campsites and vegetation substrates are provided by narrow deposits that often continuously line the channel margin in wide river reaches (U.S. Department of the Interior 1988). These channel-margin deposits are illustrated in Figure 7.

Previous studies on the effects of dam operations on alluvial deposits have produced conflicting results. Howard and Dolan (1981) found that alluvial deposits throughout the Grand Canyon had achieved stable profiles by the late 1970s, during the filling phase of dam operations ( 1963 to 1980). Other studies hypothesized that beaches below Glen Canyon Dam would vanish in 200 or more years (Ferrari 1988).

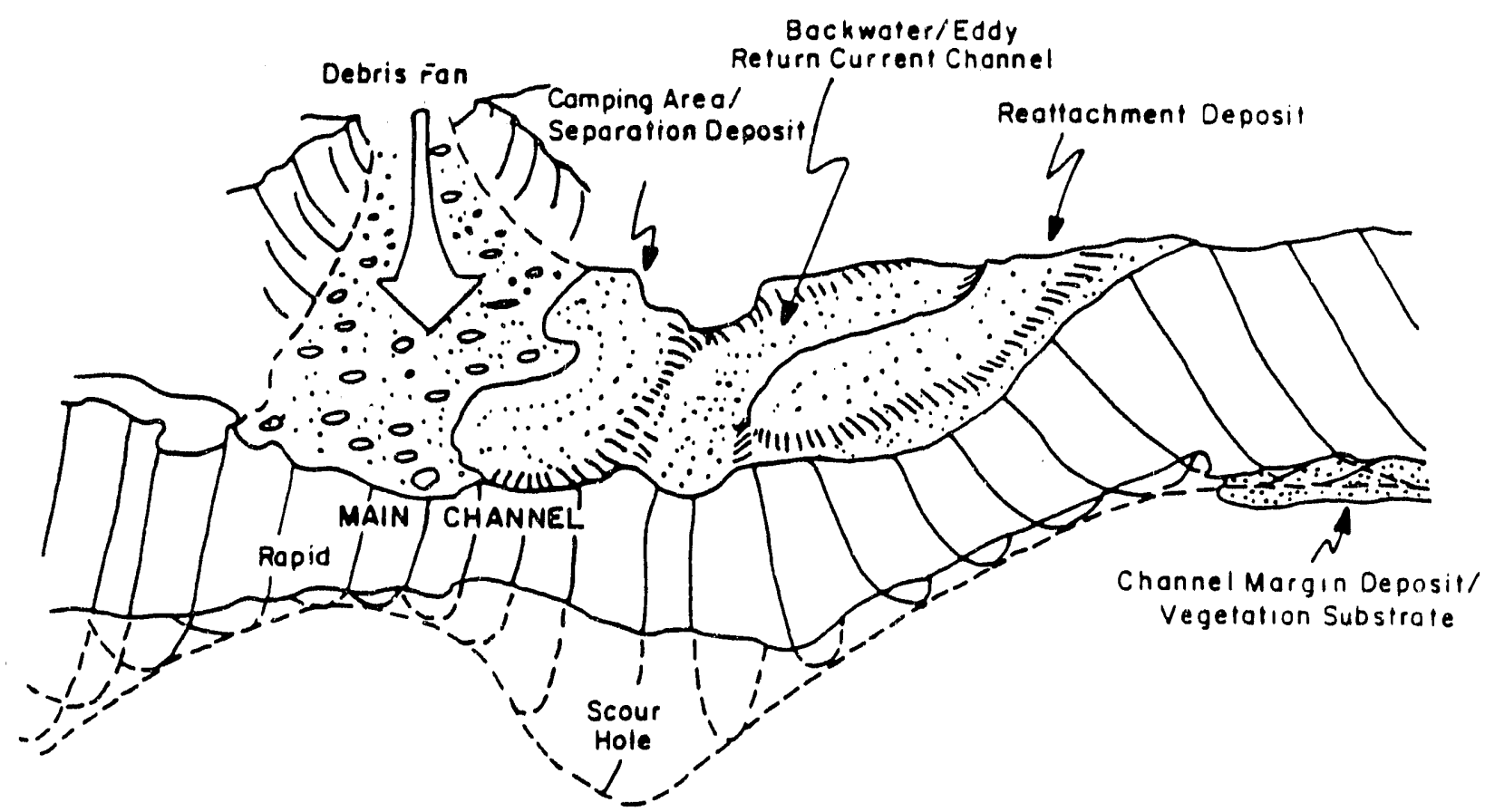

FIGURE 7 Sediment Deposits and Sediment-Dependent Resources in the Vicinity of a Typical Recirculation Zone (Source: U.S. Department of the Interior 1988) 


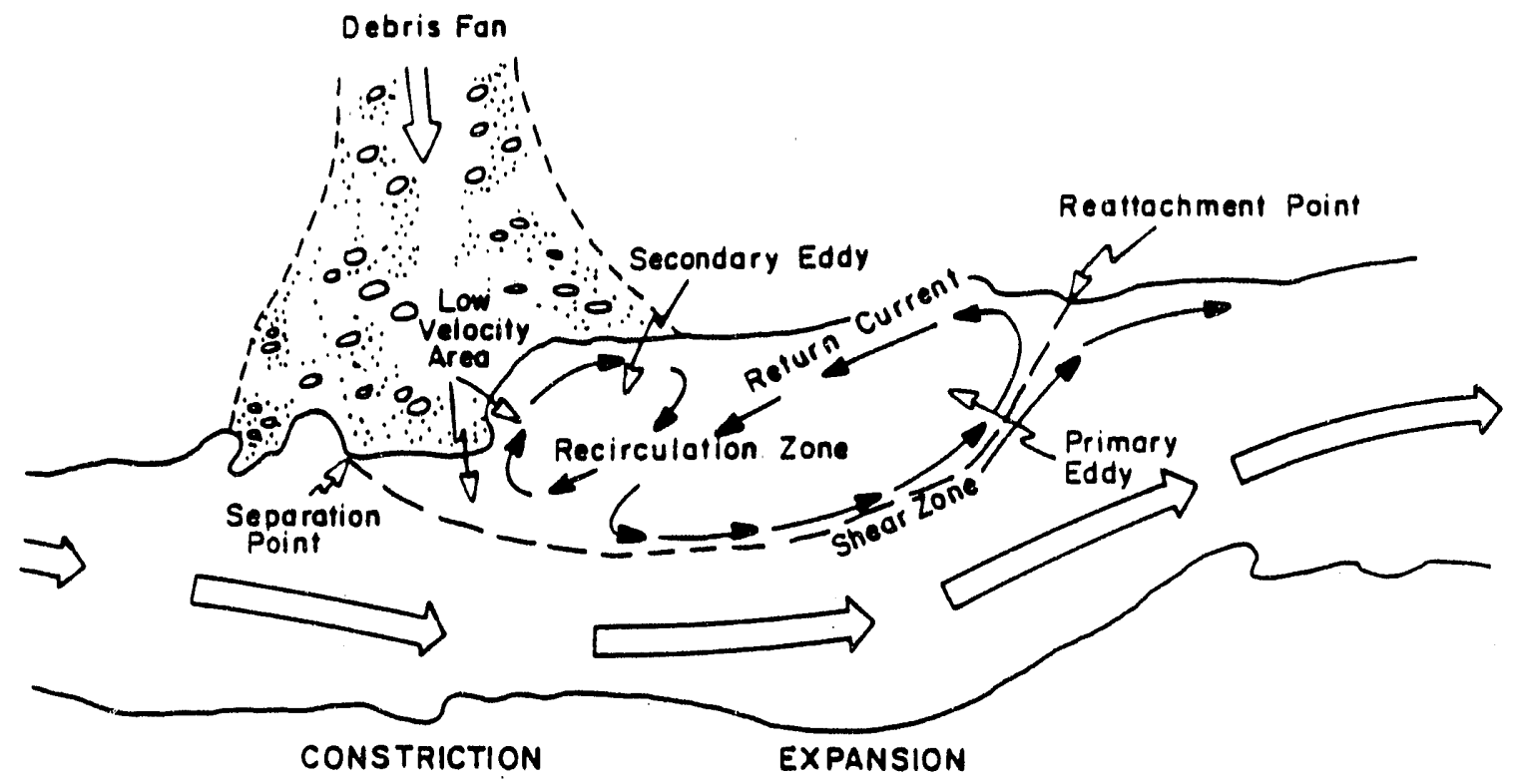

FIGURE 8 Flow Patterns at a Relatively High Discharge in a Typical Recirculation Zone, Showing Primary and Secondary Eddies (Source: U.S. Department of the Interior 1988)

In general, high flows accompanied by low-volume sediment loads increase the rate of erosion. The flood of June 1983 removed an estimated 16 million tons of sediment from the main channel of the Colorado River between Lees Ferry and Phantom Ranch (Carothers and Brown 1991). Schmidt and Graf (1988) concluded that, during the flood, sediment was eroded from recirculation zones in narrow reaches down the entire river corridor. The greatest erosion occurred in the steepest and narrowest reach, Upper Granite Gorge. In wide river reaches, on the other hand, the number of recirculation zones with separation or reattachment bars increased. Some beaches lost up to three vertical feet of sediment, while other beaches gained between one and two vertical feet (Carothers and Brown 1991).

Measurements of the change in area of major alluvial deposits indicated that the largest and highest deposits were less susceptible to change (Schmidt and Graf 1988). A summation of the area of all major alluvial sand deposits by reach indicated that no significant change in area occurred except in the reach between Lees Ferry and river mile (RM) 11.3, in which the erosion of one point-bar deposit accounted for all of the change in area. Between Glen Canyon Dam and Lees Ferry, armoring (loss of fine-grained sediments because of erosion) primarily due to the large releases of 1965,1983 , and 1984 has occurred, and a flow of more than $70,000-80,000 \mathrm{cfs}$ may be required to produce further erosion of the limited supply of sand- and gravel-sized sediments (Burkham 1988).

In addition to examining erosion in recirculation zones, Schmidt and Graf (1988) evaluated the susceptibility of separation and reattachment deposits to changes in flow. They found that the lower-elevation reattachment bars were, in general, more prone to erosion than the separation deposits. Of the total number of separation bars evaluated, about $60 \%$ 
had a change in area; about $80 \%$ of reattachment bars had changes in area. Comparisons of the area of exposed sediment at a flow of 25,000 cfs in 1973 and 1984 indicated that vertical aggradation of separation and channel-margin deposics occurred at many sites as sediment was deposited by the higher-than-normal river stage and flow.

With increasing distance from the dam, erosion decreases. Downstream of Phantom Ranch (near the confluence of Bright Angel Creek; see Figure 1), the river sediment distribution more closely approaches equilibrium, and the inflow of sediment is roughly equal to outflow. After the 1983 flood, little, if any, net loss of sediment from the riverbed occurred below Phantom Ranch (Carothers and Brown 1991).

In contrast to high flows, low flows tend to deposit sediment in main-channel pools. These pools are scoured when the flow level becomes sufficiently large to transport the sediment downstream. The mechanism of sediment removal from pools and accompanying transport to nearby reattachment, separation, or channel-margin bars or to other downstream pools is not well understood, and any prediction based on the results of Phasle I studies is speculative.

Schmidt and Graf (1988) also evaluated the impacts of strongly fluctuating flows between October 1985 and January 1986. They concluded that sediment transport in the main channel of the Colorado River is slightly higher under fluctuating flows than under steady flow conditions (U.S. Department of the Interior 1988). Predictions with the STARS model (Orvis and Randle 1987) indicated that for an annual release of 8.2 million acre-feet, a $12 \%$ decrease occurred in the amount of sediment stored in the main-channel bed during fluctuating flow conditions (Randle and Pemberton 1987). Although portions of some alluvial deposits aggraded in 1985, most deposits experienced some net erosion. At the end of the study period, cutbanks existed at many sites, indicating the presence of unstable sediment profiles. The range of change in river stage has been idontified as the most important process in determining locations of erosion (Schmidt and Graf 1988). The largest amount of erosion occurred at the elevated deposits created by the floods of 1983 and 1984. Other erosion occurred on the upper surface of reattachment bars, thus smoothing out the reattachment bar topography and reducing the number of available backwaters.

Fluctuating flows appear to have their greatest impact immediately after a flood event (U.S. Department of the Interior 1988). The newly deposited sediments are particularly susceptible to erosion, but over time, the deposits reestablish an equilibrium profile. Sediment eroded from elevated beaches because of the actions of fluctuating flow is transported to the main-channel bed (Schmidt 1987). However, the time dependence of this process is neither well understood nor documented.

The effect of ramp rates on erosion is being investigated under Phase II of the GCES. In general, higher ramp rates have been associated with higher rates of erosion, particularly during times of down ramping. Erosion is believed to occur because of seepage-face processes, but results of these studies are not yet available. 


\subsection{AQUATIC ECOLOGY}

\subsubsection{Fishes}

Before Glen Canyon Dam was constructed, the aquatic environment of the lower Colorado River was characterized by extremes in flows, temperature, and sediment load (Section 2.1). These characteristics, in conjunction with the largely isolated nature of the lower Colorado River, were responsible for the development of a relatively small and highly endemic fish community within the river. In contrast to the large Lumber of fish species (more than 100) reported in other large North American river systems, fewer than 50 species are native to the Colorado River basin, and approximately 75\% of these species are nndemic to the system. Minckley (1991) provides a review of the early reports of fish fauna in the Colorado River.

Little scientific collection of fishes in the Glen Canyon and Grand Canyon reaches of the Colorado River occurred before the construction of Glen Canyon Dam (Minckley 1991). Native fishes reported from collections made in the late $1950 \mathrm{~s}$ included roundtail chub; Colorado squawfish; speckled dace; and flannelmouth, bluehead, and razorback suckers. Introduced species (nonnative) included fathead minnow, carp, channel catfish, and green sunfish. Introduced species have been in the lower Colorado River system for quite some time. For example, carp and channel catfish were introduced in the late 1800s (Carothers and Brown 1991). Channel catfish were frequently caught by fishermen at Lees Ferry throughout the mid-1900s; during the $1970 \mathrm{~s}$, carp accounted for $70.80 \%$ of all fishes captured in the Grand Canyon. The National Park Service began a trout-stocking program in the early $1920 \mathrm{~s}$ in the Grand Clanyon, but this program was discontinued in 1964 (Carothers and Brown 1991). Following closure of Glen Canyon Dam in 1963, the Arizona Department of Game and Fish began stocking thousands of rainbow, brook, and cutthroat trout.

A total of 28 species of fishes representing 9 families and 22 genera (Table 3 ) have been reported from the lower Colorado River between Glen Canyon Dam and Lake Mead (Minckley 1991). Among these species, the native bonytail and roundtail chubs and the Colorado squawfish have been extirpated from this river reach. Of the remaining 25 species, only 5 are native, including the endangered humpback chub and razorback sucker.

Primary concern regarding potential impacts of dam operations is directed at three groups of species that exist below the dam: (1) the federally endangered humpback chub and razorback sucker, (2) the native speckled dace and bluehead and flannelmouth suckers, and (3) the recreationally important trout. 'To better understand the possible relationships between the operation of Glen Canyon Dam and endangered and native fishes and trout, it is necessary to understand the ecology and life history of these species. The life histories of endangered and native fishes that occur in the Colorado River below Glen Canyon Dam have recently been reviewed by Minckley (1991), and the following species accounts summarize 
TABLE 3 Fish Species of the Lower Colorado River between Glen Canyon Dam and Lake Mead

\begin{tabular}{|c|c|c|}
\hline Family & Common Name & Scientific Name \\
\hline Clupeidae & Threadfin shad ${ }^{a}$ & Dorosoma petenense \\
\hline Salmonidae & $\begin{array}{l}\text { Apache trout } \\
\text { Cutthroat trout } \\
\text { Silver salmon } \\
\text { Rainbow trout } \\
\text { Brown trout } \\
\text { Brook trout } \\
\text { a }^{\mathrm{a}}\end{array}$ & $\begin{array}{l}\text { Oncorhynchus apache } \\
\text { O. clarki } \\
\text { O. kisutch } \\
\text { O. mykiss } \\
\text { Salmo trutta } \\
\text { Salvelinus fontinalis }\end{array}$ \\
\hline Cyprinidae & $\begin{array}{l}\text { Humpback chub } \\
\text { Bonytail chub } \\
\text { Roundtail chub } \\
\text { Colorado squawtish } \\
\text { Speckled dace }{ }^{b} \\
\text { Common carp } \\
\text { Red shiner } \\
\text { Golden shiner }^{\mathrm{a}} \\
\text { Fathead minnow } \\
\text { Redside shiner } \\
\text { Red }^{\mathrm{a}}\end{array}$ & $\begin{array}{l}\text { Gila cypha } \\
\text { G. elegans } \\
\text { G. r. robusta } \\
\text { Ptychocheilus lucius } \\
\text { Rhinichthys osculus } \\
\text { Cyprinus carpio } \\
\text { Cyprinella lutrensis } \\
\text { Notemigonus crysoleucus } \\
\text { Pimephales promelas } \\
\text { Richardsonius balteatus }\end{array}$ \\
\hline Catostomidae & $\begin{array}{l}\text { Flannelmouth sucker } \\
\text { Bluehead sucker } \\
\text { Razorback sucker } \\
\text { b,c }\end{array}$ & $\begin{array}{l}\text { Catostomus latipinnis } \\
\text { Pantosteus discobolus } \\
\text { Xyrauchen texanus }\end{array}$ \\
\hline Ictaluridae & $\begin{array}{l}\text { Black catfish } \\
\text { Channel catfish }\end{array}$ & $\begin{array}{l}\text { Ameiurus melas } \\
\text { Ictalurus punctatus }\end{array}$ \\
\hline Fundulidae & Plains killifish & Fund nlus zebrinus \\
\hline Poeciliidae & Mosquitofish $^{a}$ & Gambusia affinis \\
\hline Centrarchidae & $\begin{array}{l}\text { Green sunfish }{ }^{a} \\
\text { Bluegill }^{\mathrm{a}} \\
\text { Largemouth bass }\end{array}$ & $\begin{array}{l}\text { Lepomis cyanellus } \\
\text { L. machrochirus } \\
\text { Micropterus salmoides }\end{array}$ \\
\hline Percichthyidae & Striped bass $^{\mathrm{a}}$ & Morone saxatilis \\
\hline
\end{tabular}

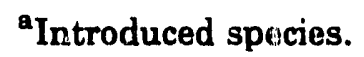

bNative species.

cFederally listed as endangered.

${ }^{d}$ Extirpated from the lower Colorado Riyer between Glen Canyon Dam and Lake Mead.

Source: Modified from Minckley (1991). 
that review and information provided in the Glen Canyon Environmental Studies Final Report (U.S. Department of the Interior 1988), the Humpback Chub Recovery Plan (U.S. Fish and Wildlife Service 1990), and a status review of the razorback sucker (Bestgen 1990). The discussion of trout is based primarily on information provided in the GCES final report and in Carothers and Brown (1991) and is supplemented with information from various literature sources.

\subsubsection{Humpback Chub}

The federally endangered humpback chub is a long-lived (20 or more years) fish that is restricted to the largest rivers and tributaries of the Colorado River system. The historic distribution of the humpback chub included portions of the mainstream Colorado River and four of its major tributaries: the Green, Yampa, White, and Little Colorado rivers. Within the lower Colorado River basin, the present distribution of this species is limited to the Marble and Grand canyons and is centered on the Little Colorado River (Valdez 1991). Within this range, more than 4,000 specimens have been collected from the main stem and the Little Colorado River since 1984, and the humpback chub has been the most abundant fish collected from the Little Colorado River over the past 14 years. In the Little Colorado River, this species occurs from the mouth of the river to eight miles upstream.

The Little Colorado River contains the largest population of humpback chubs in the lower basin of the Colorado River and is the only known area of reproduction for this species within the Grand Canyon region. Successful reproduction in the main stem of the Colorado River has not been recorded recently, possibly as a consequence of the cold hypolimnetic releases from Lake Powell. Although spawning may occur in main-stem areas, cold water probably prevents successful development and hatching of eggs, because hatching success is strongly affected by temperature. In the laboratory, hatching success of eggs obtained from wild fish collected from the Little Colorado River was greatest, $60 \%$, at $20^{\circ} \mathrm{C}$, but only $0.8 \%$ at $15^{\circ} \mathrm{C}$ and $2.0 \%$ at $25^{\circ} \mathrm{C}$. Main-stem temperatures rarely reach $16^{\circ} \mathrm{C}$ in springtime; successful development and hatching of humpback chub eggs has been reported to require temperatures of $15^{\circ} \mathrm{C}$ or higher, while natural reproduction in the Little Colorado River has been reported to occur at temperatures of $16-22^{\circ} \mathrm{C}$.

Adult fish from the main stem of the Colorado River move to the mouth of the Little Colorado River in the spring and use this area to stage upstream movement into the Little Colorado River to spawn. Spawning of the humpback chub in the Little Colorado River occurs in the spring, between May and July, and possibly as early as March. Estimates indicate a spring population of about 7,000-10,000 adult fish near the mouth of the Little Colorado River. Humpback chub spawning has been documented in the lower 6.8 miles of the Little Colorado River; however, it is unknown where eggs are deposited (i.e., pools, riffles, eddies, and runs). Hatchery observations suggest that gravel bars or cobble raceways serve as spawning areas (Valdez and Clemmer 1982). 
After hatching, larvae either remain in the Jittle Colorado River or move downstream to the mouth of the river, which serves as a nursery area. By autumn, larval humpback chubs may reach two inches long. At this size, young fish can withstand colder water, and some individuals move out of the Little Colorado River and into backwater and nearshore low-velocity habitats in the main stem of the Colorado River.

Humpback chubs have been collected from a variety of habitats; the general preference seems to be deep, swift canyon habitats and the low-velocity mouth of the Little Colorado River. In the main stem of the Colorado River in the Grand Canyon region, adults have been associated with cliffs and boulders, eddies adjacent to fast currents, and backwaters with sand bottoms and depths of 6.5-16 feet. In the Little Colorado River, they are found in deep pools near rapids and eddies. Ynung humpback chubs are often collected from habitats similar to those occupied by adults, while young-of-the-year are reported in sandy runs, backwaters, creek mouths, and flatwater areas.

Observations of adult and young humpback chubs in the Little Colorado River indicate that they foiage on the bottom, while specimens collected below Glen Canyon Dam were found to have fed primarily on planktonic crustaceans. Adult humpback chubs from the upper Colorado River basin have been reported to feed on insects at the water surface. Stomach contents of adults collected from the Grand Canyon region mostiy consisted of larval midges (Chironomidae) and black flies (Simuliidae). Aquatic invertebrates and algae were found in the stomachs of three young-of-the-year humpback chubs collected from the Little Colorado River.

\subsubsection{Razorback Sucker}

The federally endangered razorback sucker was once widespread throughout the Colorado River basin but now remains abundant only in Lake Mohave in Arizona and Nevada. The population in Lake Mohave is estimated at approximately 50,000 adults and probably represents the largest remaining concentration of this species in its current range. The razorback sucker is rare or absent in the remainder of the lower Colorado River basin, with smaller numbers present in Lake Mead, in Senator Wash Reservoir (California), and below Hoover Dam. The razorback sucker is also rare in the upper Colorado River basin, where about 1,000 fish are estimated to occur.

Within the Colorado River drainage below Glen Canyon Dam, the razorback sucker is very rare. Thirteen individuals have been collected within the Marble Canyon and Grand Canyon reaches of the Colorado River from 1978 to 1990. The collection of these fish over a 12-year period indicates that a remnant population exists in this portion of the lower Colorado River. All individuals collected were large and presumably old adults, and there is no evidence of successful reproduction and recruitment within the Grand Canyon portion of the Colorado River.

Because the razorback sucker is rare in the Colorado River below Glen Canyon Darn, little is known about its life history in the Grand Canyon region. This species has been 
reported to use a variety of habitats, ranging from low-velocity areas such as backwaters, sloughs, and oxbow lakes to higher-velocity and more mainstream areas such as nearshore runs and channels. During the spring, razort... $k$ suckers congregate in warmer backwaters and eddies.

Spawning of razorback suckers in the upper Colorado River basin is presumably similar to that of reservoir fish. Spring spawning occurs under conditions of rising water levels and temperatures. In the upper basin, this species spawns in May and June when water temperatures exceed $16^{\circ} \mathrm{C}$, while spawning in lower basin reservoirs begins as early as November and continues through May at water temperatures of $10-20^{\circ} \mathrm{C}$.

Very little is known of the growth and ecology of young razorback suckers; few juveniles have been collected, and most growth information is based on hatchery-derived fish, for which growth rates are highly variable. The food habits of razorback suckers are not well known. In ponds and reservoirs, the razorback sucker appears to feed on plankton. The diets of larvae have been found to consist primarily of phytoplankton and small zooplankton, while the diets of adults predominantly consist of zooplankton and lesser amounts of algae and detritus. In contrast, razorback sucker larvae collected from the Salt River in Arizona had midge larvae as the dominant food item. Adult razorback suckers collected from riverine environments contained benthic organisms such as immature mayflies (Ephemeroptera), caddisflies (Trichoptera), and midge larvae, along with some algae, detritus, and inorganic matter.

\subsubsection{Flannelmouth Sucker}

The flannelmouth sucker (a federal candidate for listing) has a healthy, reproducing population in the Colorado River between Glen Canyon Dam and Lake Mead. The species is also relatively abundant and widespread throughout the upper Colorado River basin. The flannelmouth sucker is extirpated in the Colorado River below Lake Mead.

In the Marble Canyon and Grand Canyon reaches of the Colorado River, spawning of the flannelmouth sucker occurs in spring in most of the larger and lower-gradient tributaries and their mouths. Breeding individuals have been collected from the mouth of the Paria River from March to May at water temperatures of $17-23^{\circ} \mathrm{C}$. It is not known if this species spawns in the main stem of the Colorado River. Adults remain in the Paria River (particularly the mouth) through the summer until the temperatures of the Paria and the main stem of the Colorado River equilibrate in the winter. Young congregate in and downstream of riffles and along the shorelines of pools; they apparently remain in the tributaries for two to three years after hatching before they enter the main stem of the Colorado River. Main-stem habitats used by the adult flannelmouth sucker include backwaters and runs, and adults are most abundant between Glen Canyon Dam and the Paria River (Maddux et al. 1987). .

The diet of the flannelmouth sucker in the Marble Canyon and Grand Canyon reaches of the Colorado River and its tributaries consists largely of midge larvae and 
zooplankton, with other invertebrate groups such as blackflies being consumed at much lower levels. The alga Cladophora glomerata is also consumed by individuals in the main stem but is rarely found in the diets of flannelmouth suckers collected from tributaries.

\subsubsection{Bluehead Sucker}

The bluehead sucker is widely distributed throughout the Colorado River basin and elsewhere in the West. Healthy reproducing populations are present in the Colorado River and its tributaries below Glen Canyon Dam. The bluehead sucker occupies deep pools and eddies during the daytime and moves to shallow riffle and hard-bottomed nearshore habitats at night. Within the main stem of the Colorado River below Glen Canyon Dam, the bluehead sucker is most abundant in the lower reaches (Maddux et al. 1987).

The bluehead sucker spawns over mixed sand/gravel or gravel/cobble bottoms in moving-water portions of the tributaries in the Grand Canyon reach of the Colorado River. The Little Colorado River, Kanab Creek, and Shinumo Creek are three of the major tributaries where bluehead suckers spawn (Maddux et al. 1987). Spawning typically occurs in April and May at water temperatures of $16-20^{\circ} \mathrm{C}$, and young appear in May and June. Young fish remain in the tributaries for two to three years before they move into the main stem of the Colorado River.

Sigler and Sigler (1987) report algae to be the fish's primary food; aquatic invertebrates living in the algae are eaten incidentally. The bluehead sucker is a good forage fish and is used as bait for carnivorous game fishes. This species is considered particularly valuable in converting algae into fish food. In parts of the Green and Bear rivers, this species is an important link in the food chain of predatory fishes, especially trout (Sigler and Sigler 1987).

\subsubsection{Speckled Dace}

The speckled dace is the most widespread freshwater fish west of the Rocky Mountains. Its range extends from Canada to southern Arizona and California. Within this range it is found in a variety of habitats, including desert springs, creeks, rivers, and high mountain brooks and lakes. It is the only fish species native to all the major western drainage systems.

In the lower Colorado River system below Glen Canyon Dam, the speckled dace reproduces only in warm tributaries; the cold water temperatures preclude successful reproduction in the main channel. Adults enter tributaries as early as March and begin spawning in April and May at water temperatures of $17-23^{\circ} \mathrm{C}$. The young and adults remain in the tributaries until winter and then enter the main stem of the Colorado River.

The speckled dace is a bottom-dwelling species, and adults feed primarily on benthic invertebrates and organic debris. Algae constitute up to $21 \%$ of the diet (by volume) in some 
populations (Sigler and Sigler 1987), and some individual fish may occasionally feed on the eggs and larvae of other fishes.

\subsubsection{Trout}

Six species of trout have been introduced into the Colorado River and its tributaries between Glen Canyon Dam and Lake Mead (Table 3). Among these species, the rainbow trout is now the most valued recreational fish in the system and since the late $1970 \mathrm{~s}$ has replaced the carp as the dominant fish in the Colorado River between Glen Canyon Dam and Lake Mead. The rainbow trout population in the river consists of stocked individuals, as well as a naturally leproducing group that spawns in the main stem above Lees Ferry and in many of the tributaries below Lees Ferry. Brown and brook trout are also present in the system as naturally reproducing populations but are much less abundant than the rainbow trout. The other trout reported in the lower Colorado River (Table 3) are much less common, and some species, such as the cutthroat trout, may not successfully reproduce in the system. Because of the importance of the rainbow trout below Glen Canyon Dam, the following discussion focuses primarily on that species.

Trout were first introduced into the tributaries of the lower Colorado River in the

Marble Canyon and Grand Canyon reaches in the 1920s. Because of the warm water temperatures in the main stem, trout used the main channel only during the winter. During that time, the trout spread to other tributaries in the lower Colorado River. Until it discontinued the program in 1964, the National Park Service had stocked more than 1.8 million fertile eggs and fingerlings into Bright Angel, Havasu, Clear, Phantom, Tapeats, Shinumo, and Garden creeks. No attempts were made before 1964 to stock trout in the Colorado River.

After Glen Canyon Dam was completed and the summer river water temperatures decreased to below $16^{\circ} \mathrm{C}$, the Arizona Department of Game and Fish began stocking rainbow, brook, and cutthroat trout into the tailwaters of Glen Canyon Dam. Because of the constant cold water temperatures and the stocking program, the Glen Canyon Dam tailwater trout fishery has become one of the finest in the southwestern United States. Now rainbow trout are found throughout the Colorado River and its tributaries from Glen Canyon Dam to Lake Mead. Recent studies estimated a rainbow trout population of about 100,000 in a 16 -mile reach of the Colorado River above Lees Ferry (Kubly 1991).

Below Glen Canyon Dam, rainbow trout spawn both in the main stem of the Colorado River and in its tributaries. Above Lees Ferry, spawning occurs primarily in the main stem on gravel and cobble bars in shallow water one to three feet deep. Reproduction iri this area appears to be for the most part unsuccessful. In contrast, successful spawning in the main stem by rainbow trout is more common below Lees Ferry. Successful reproduction also occurs in many of the major tributaries below Lees Ferry, including Nankoweap, Clear, Bright Angel, Tapeats, and Deer creeks. Spawning runs in these creeks typically occur from November through March. 
Rainbow trout eggs usually hatch within four to seven weeks. Hatching time and yolk-sac absorption are strongly affected by habitat type, spawning time, and the thermal environment after egg laying. The fry begin feeding within 15 days of hatching and emerge from the redds (nests) from mid-June to mid-August if spawning takes place in April or May. Upon emerging, the fry move out into the river or stream.

The diets of adult rainbow trout in the Colorado River below Glen Canyon Dam consist primarily of the alga Cladophora, aquatic insect larvae, and the amphipod Gammarus. The relative contribution to the diet of each of thess food items varies with river reach and with season. Cladophora is most abundant in the diet in summer and least in winter, while insect larvae and Gammarus are most abundant in winter and lowest in summer. It is unclear whether nourishment is derived from the consumption of algae or if the intake of algae is incidental as other foods are consumed.

\subsubsection{Aquatic Food Base}

Limited information is available regarding the algal and aquatic invertebrate communities that existed in the lower Colorado River before construction and closure of Glen Canyon Dam. Blinn and Cole (1991) reviewed the pre- and post-dam algal and invertebrate biota within the lower Colorado River, and the following discussions briefly summarize their review.

River conditions before the dam was constructed included low light transmittance (as a result of high sediment loads), high summer temperatures, large seasonal temperature variations, annual floods depositing large amounts of silt and sand, and a seasonally fluctuating water chemistry. Since closure of the dam in 1963, the nature of the river has changed dramatically, resulting in a marked change in the aquatic food base within the main channel of the river. Closure of the dam has resulted in very clear water with relatively stable temperature and chemistry, especially above Lees Ferry. Inputs from tributaries increase the sediment load in the main channel downstream from the dam, resulting in a gradient of increasing sediment load and turbidity and of decreasing light transmittance. The aquatic food base responds to and changes along these gradients (Figure 9).

Numerous aquatic invertebrates have been introduced into the system, primarily to supply forage for trout (Blinn and Cole 1991). These introductions have included Gammarus lacustris into Bright Angel Creek in 1932, and mayfly larvae, other insects, snails, leeches, and crayfish into the main stem of the Colorado River in 1967.

Among the current algal and invertebrate communities of the Colorado River between Glen Canyon Dam and Lake Mead, the most important foods for fishes are Cladophora glomerata, Gammarus lacustris, several diatom species that are epiphytic on Cladophora, and some aquatic insect larvae, such as midges and blackflies. 

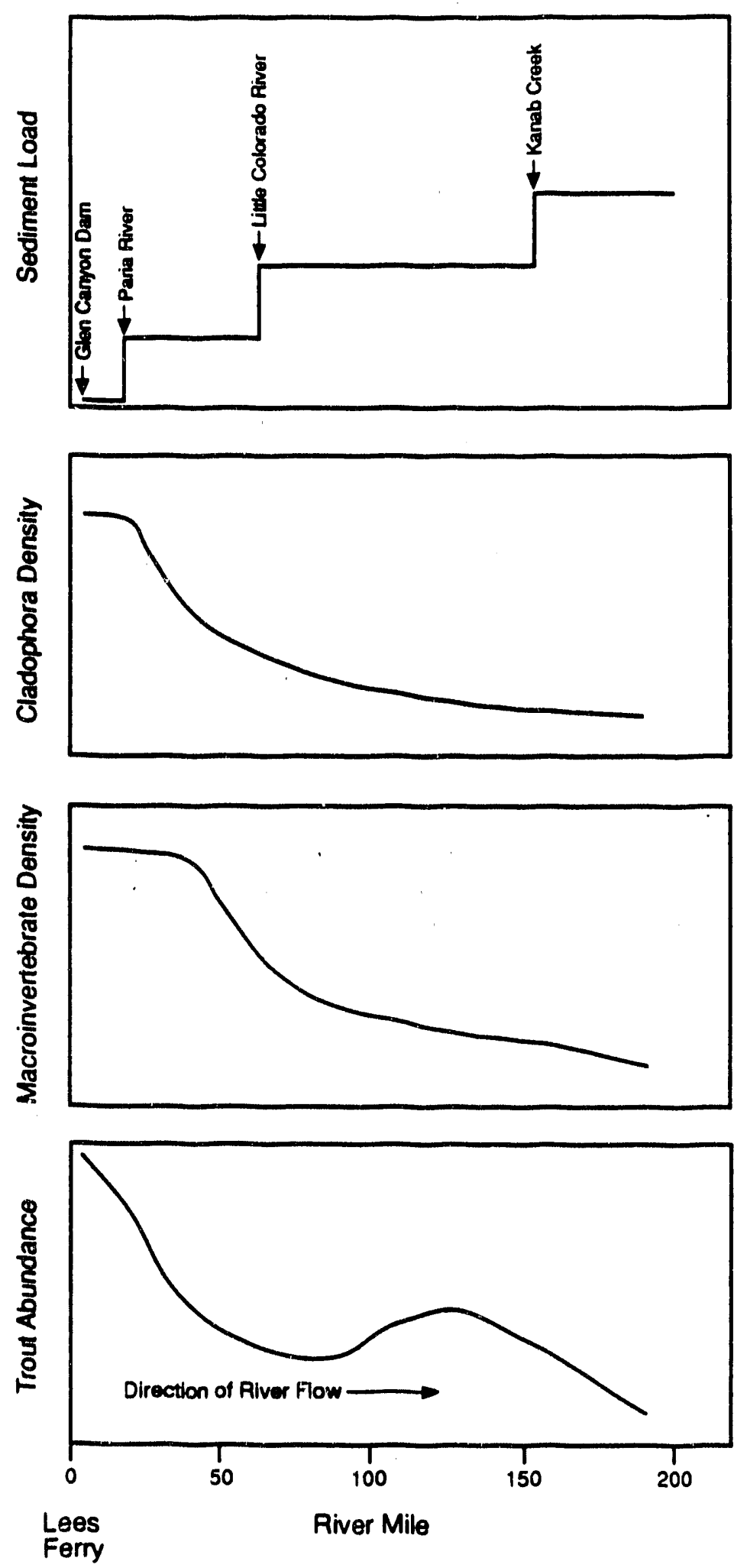

FIGURE 9 Distribution of Cladophora, Aquatic Macroinvertebrates, and Trout in the Colorado River Downstream of Glen Canyon Dam (Source: Modified from Carothers and Brown 1991) 


\subsubsection{Cladophora glomerata}

Cladophora glomerata is the dominant alga in the Colorado River between Glen Canyon Dam and Lake Mead. Cladophora is a highly branched filamentous green alga that attaches to hard substrates with the use of specialized cells located at its base. Its highly branched filaments provide suitable habitat for a variety of aquatic biota, including insect larvae, amphipods, snails, and diatoms. This species exhibits the greatest growth in spring and autumn and a sharp decrease in growth in midsummer (Usher et al. 1987).

Cladophora is particularly abundant between the dam and the Paria River and at the mouths of tributaries. The abundance of this alga in the tailwaters is related to the abundance of hard, stable rock surfaces that are used for attachment and to the release of clear, nutrient-enriched waters from Lake Powell. Standing crop estimates of Cladophora in the tailwaters average about $144 \mathrm{~g} / \mathrm{m}^{2}$, and below Lees Ferry, biomass averages approximately $17.2 \mathrm{~g} / \mathrm{m}^{2}$ (Blinn and Cole 1991). The decrease in standing crop is believed to result from the periodic input of sediments from tributaries such as the Paria and Little Colorado rivers and from sediment-driven abrasion (Figure 9). The increasing sediment input reduces light transmittance.

Cladophora serves as a substrate for a variety of aquatic invertebrates, including chironomids and Gammarus, and also for a number of epiphytic diatoms. Thus, in addition to its potential importance in the diet of bluehead suckers and rainbow trout, Cladophora supplies habitat for a variety of other aquatic organisms that are important food items for aquatic invertebrates and fishes.

\subsubsection{Gammarus lacustris}

The amphipod Gammarus lacustris is one of the most important food items for native and introduced fishes in the Colorado River between Glen Canyon Dam and Lake Mead. The longitudinal distribution of Gammarus below Glen Canyon Dam is similar to that exhibited by Cladophora (Figure 9). Average densities of Gammarus range from 95 individuals per square meter above the Little Colorado River to 26 individuals per square meter below the Little Colorado River (Leibfried and Blinn 1987).

Gammarus uses a variety of foodstuffs and typically browses on microscopic plant and animal materials that cover plants, rocks, and other submerged substrates. These amphipods are primarily benthic and typically occur in water less than three feet deep. They prefer cold water, which is one of the reasons they have become so well established in the Glen Canyon Dam tailwaters. Gammarus reacts negatively to light, and as a result individuals remain hidden in debris and vegetation, such as Cladophora, during the daytime. Reproiktion occurs between February and October, depending on water temperature. 


\subsubsection{Habitats}

Several habitat types that are important for the endangered and native fishes and for trout and that may be affected by opierations of Glen Canyon Dam have been identified and targeted for protection by some of the proposed operating criteria. These habitats include trout spawning areas in the Glen Canyon Dam tailwaters, backwaters and side channels, and tributary mouths. Trout-spawning areas most affected by dam operations are located primarily in the tailwaters above Lees Ferry. These spawning areas consist of gravel and cobble bars in shallow water one to three feet deep. These habitats also occur downriver of Lees Ferry, but they are less affected by dam operations. In addition, spawning habitats exist in many of the tributaries that also are not affected by dam operations.

The backwater, side-channel, and tributary-mouth habitats are important to many species, and use of these habitats often overllaps spatially and temporally. In summer and in autumn, these habitats may serve as important nursery areas for a number of species. In comparison with the main-channel, the backwater and side-channel habitats at these times are typically warmer and exhibit reduced currents. The warmer and calmer waters provide better conditions for growth of the young of many fish species. Because of thermal, chemical, 'and flow conditions that differ from those of the main stem, backwaters and tributary mouths may also serve as staging and resting areas for spawning activities, such as upstream migrations into tributaries. Pools that occur at the mouth of the Little Colorado River in summer serve as nursery areas for the humpback chub; young chubs use this habitat to grow big enough to tolerate main-channel conditions by autumn.

\subsubsection{Effects of Glen Canyon Dam Operations}

The presence of Glen Canyon Dam has resulted in numerous downstream changes in the Colorado River. Changes in river flow and sediment load are discussed in Section 2.1. In addition to those changes, the thermal regime of the river has been dramatically altered, and this change has had a major adverse impact on the endangered and native fishes in the river. The thermal change has included the absence of warm water in summer; the warm summer water has been replaced with water too cold to allow successful reproduction and larval development of native species.

Aquatic biological resources in the Colorado River between the Glen Canyon Dam and Lake Mead also may experience adverse effects as a result of the daily and seasonal operations of the dam. Potential adverse impacts on the aquatic biota have been linked to three different hydrological regimes that are under the direct control of dam operations: high flows, low flows, and fluctuating flows.

High releases from Glen Canyon Dam may adversely affect aquatic biological resources in three ways. First, high flows may flood nursery areas in backwaters and tributary mouths, exposing young fishes to colder water and main-channel predators. Second, flooding of nursery areas may result in the transport of young fishes from the warm waters of these areas to lethally cold main-channel waters. Jast, high flows may remove aquatic 
invertebrates and other benthic organisms and submerged vegetation such as Cladophora from some areas.

Low flows may affect aquatic resources in several ways. Low flows can dewater nursery areas in backwaters and tributary mouths. In addition to this loss of nursery habitat, water draining from a nursery area can transport young fishes into the harsh mainchannel environment. If sufficiently dewatered, the mouth of the Little Colorado River may not be suitable as a staging area for spawning humpback chubs or as a nursery area for young humpback chubs. Low flows can adversely affect the aquatic food base, as well as trout redds and spawning areas of other fishes, by dewatering these resources and exposing them to desiccation, or allowing accumulation of sediments. Low flows may also strand young fishes in isolated backwaters and young and adult fishes in other areas, such as gravel and sand bars.

Daily flow fluctuations can alternately flood and dewater backwater and tributary mouths and trout redds. The impacts identified for high and low flows apply to fluctuating flows. The magnitude of these impacts is thought to be directly related to the magnitude and rate of the fluctuations. Secondary effects on biota may result from the loss of nursery habitat and the aquatic food base as a result of increased bank and beach erosion.

\subsection{RIPARIAN ECOLOGY}

Below Glen Canyon Dam, Glen and Grand canyons contain 292 miles of riparian habitat along the Colorado River. This habitat is the largest protected riparian corridor in the western United States (Anderson and Ruffner 1987). Before Glen Canyon Dam was closed in 1963, two zones of riparian vegetation occurred along the Colorado River in Glen and. Grand canyons (Anderson and Ruffner 1987; U.S. Department of the Interior 1988). Closest to the river, in the area exposed to annual scouring floods, ephemeral herbaceous and short-lived woody species became established between floods (Figure 10). Above this elevation (approximately the 90,000-cfs level), the plant community consisted of long-lived shrubs and trees that depended on occassional elevated flows to provide suitable substrates, nutrients, and groundwater necessary for growth and reproduction (Anderson and Ruffner 1987; U.S. Department of the Interior 1988). This "old high-water zone" community was dominated by western honey mesquite (Prosopis glandulosa), catclaw acacia (Acacia greggii), apache plume (Fallugia parndoxa), redbud (Cercis occidentalis), and netleaf hackberry (Celtis reticulata) (Anderson and I uffner 1987). The upper limit of the old high-water zone was apparently determined by soL'-moisture levels and soil depth (U.S. Department of the Interior 1988).

Riparian vegetation in the old high-water zone has remained relatively stable since the completion of Glen Canyon Dam (Pucherelli 1986). Concern over the long-term consequences of flood control on this riparian habitat prompted studies of growth and reproduction in the two dominant plant species in this habitat: western honey mesquite and 

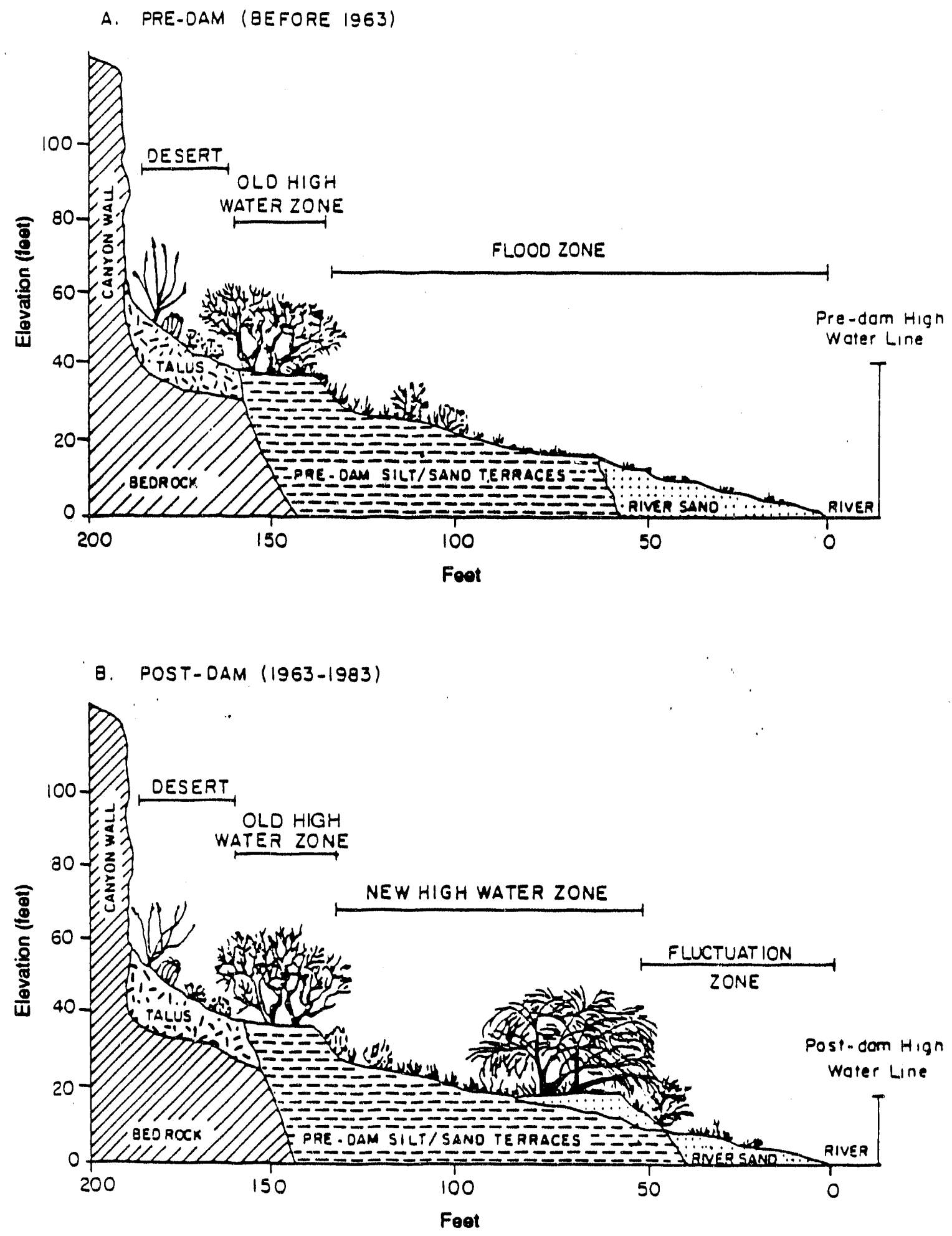

FIGURE 10 Riparian Vegetation Zones in Glen and Grand Canyons before and after Completion of the Glen Canyon Dam (Source: U.S. Department of the Interior 1988) 
catclaw acacia. Growth of mature trees appears to have slowed following dam closure (Anderson and Ruffner 1987). Reproduction of both species has occurred in both the old highwater zone and new high-water zone (see below), but the greater survivorship of seedlings in the latter area suggests an eventual shift of the community closer to the river's edge (Anderson and Ruffner 1987).

One of the most noticeable changes in the riverine environment that resulted from construction of Glen Canyon Dam was the establishment of a new riparian plant community, termed the "new high-water zone," that consists of long-lived plant species established in the old ephemeral zone at and above the 31,500-cfs level (Figure 10) (Carothers and Brown 1991). Establishment of long-lived species at these lower elevations was the result of the elimination of large annual floods that removed vegetation below the 90,000-cfs level. A rapid increase in riparian habitat $(0.5 \mathrm{acre} / \mathrm{mi} \cdot \mathrm{yr})$ in the new high-water zone occurred during the first 10 years after dam closure (Pucherelli 1986). This rate of increase slowed as the riparian community reached an equilibrium with the new flow regime $(0.3 \mathrm{acre} / \mathrm{mi} \cdot \mathrm{yr})$.

The new high-water zone is dominated by a mix of native and nonnative species, including tamarisk (Tamarix chinensis), desert broom (Baccharis spp.), willows (Salix spp.), and arrowweed (Pluchea sericea) (Pucherelli 1986). This habitat supports large populations of invertebrates and provides habitat for a variety of terrestrial reptiles, mammals, and birds, including the southwestern willow flycatcher (Empidonax trailii extimus, a federal candidate for listing) and the peregrine falcon (Falco peregrinus, federally listed as endangered) (Johnson 1991; Carothers and Brown 1991). Animal diversity was not as great within the river corridor before the new high-water zone habitat was established.

Below the new high-water zone is the area affected by fluctuating flows from the dam (Figure 10). This zone is comparable to the old flood zone in that periodic scouring and inundation prevent colonization by long-lived plant species. However, within the fluctuation zone, marsh vegetation (mostly cattail, Typha latifolia; horsetail, Equisetum hyemale; and bullrush, Scirpus validus) has colonized some protected beaches, backwater areas, and tributary mouths where fine sediments have accumulated (Carothers and Brown 1991; U.S. Department of the Interior 1991b). Marshes were not present along the Colorado River in Glen Canyon or Grand Canyon before Glen Canyon Dam was closed. Although these communities represent a small portion of the river corridor (about 40 acres), they provide important animal habitat.

The filling of Lake Powell in 1980 increased the probability of floods below the dam because of the reservoir's decreased flood-control capacity; in the wet year of 1983, flows in excess of $90,000 \mathrm{cfs}$ occurred below the dam (U.S. Department of the Interior 1990; Stanford and Ward 1991). This flood and others in the subsequent wet years of 1984 to 1986 significantly reduced (by about $49 \%$ ) plant cover in the new high-water zone that was inundated by floodwaters (Pucherelli 1986; Stevens and Waring 1986; Brian 1987). Marshes suffered even greater losses; up to $95 \%$ of marshes were eliminated from the area (Stevens and Waring 1986; Carothers and Brown 1991). Inundation of riparian habitat resulted in the loss of nests of bird species that typically nest near the high-water line, such as the common 
yellowthroat (Geothlypis trichas), Bell's vireo (Vireo bellii), and yellow-breasted chat (Icteria virens). Losses for these species were estimated at $100 \%, 60 \%$, and $11 \%$, respectively, of active nests in the riparian corridor below the dam (Brown and Johnson 1987). Lizard species that prefer shoreline habitats, such as the side-blotched lizard (Uta stansburiana), western whip-tailed lizard (Cnemidophorus tigris), and desert spiny lizard (Sceloporus magister), also were adversely affected by the 1983 flood (Warren and Schwalbe 1987). The lack of floods since 1986 has allowed vegetation and wildlife in the new high-water zone to begin recovery (U.S. Department of the Interior 1991a).

In contrast to the adverse effects of flooding on new high-water zone and marsh vegetation, the 1983 flood resulted in a slight increase in plant cover in the old high-water zone, presumably because of an increase in soil moisture and replenishment of nutrients (Brian 1987). Occasional floods of this magnitude appear to be necessary for the long-term maintenance of this community (Pucherelli 1986; Brian 1987; Carothers and Brown 1991).

Studies focusing on the effects of fluctuating flows on riparian plant communities have not been conducted (National Academy of Sciences 1987). Riparian plant communities within the new high-water zone and old high-water zone are above the level of fluctuating flows and thus should not be affected directly by such fluctuations (Anderson and Ruffner 1987; Brian 1987). However, it has been suggested, that fluctuating flows could affect these communities indirectly through erosion of beaches and other sediment deposits used by riparian plants (Brian 1987; Anderson and Ruffner 1987) and leaching of nutrients necessary for plant maintenance and growth (Stevens and Waring 1986; Anderson and Ruffner 1987). Both of these potential impacts could affect the long-term persistence of these communities within the systern. The effects of fluctuating flows on marshes have not been studied, but the occurrence and persistence of marshes within the zone of fluctuation indicate their ability to tolerate such fluctuations. 


\section{EVALUATION OF PROPOSED INTERIVI OPERATING CRITERIA}

The proposed Glen Canyon Dam interim operating criteria evaluated in this report are summarized in Table 1, and the resources targeted for protection by these criteria are presented in Table 2. The scientific basis for each set of proposed operating criteria is evaluated in this section for each resource of concern.

\subsection{MAXIMUM FLOW}

\subsubsection{Hydrology}

The maximum release from Glen Canyon Dam is 20,000 cfs under each of the proposed interim flow regimes. This constraint has the objective of minimizing erosional impacts downstream of Glen Canyon Dam, particularly in the reach between the Paria and Little Colorado rivers (U.S. Department of the Interior 1991a). This recommendation is based on the following information: a sediment-load curve (Figures 11 and 12) developed from data measured between 1983 and 1986 at the Grand Canyon gauge, the preliminary finding that discharges above $20,000 \mathrm{cfs}$ accelerate erosion of perched beach sand and deposits and cause lateral bank erosion (Pemberton 1988), and reconnaissance observations made by Schmidt in 1990 and 1991.

As discussed in Sections 2.1.2 and 2.1.3, higher flows change the sediment distribution in the river corridor. Sediment load is increased with increasing flow as pools are scoured and low-lying deposits are eroded. At the same time, the increased sediment load can produce aggradation in higher-elevation deposits, such as separation bars, and in deposits in wide reaches of the river. As depicted in Figures 11 and 12, increases in flow increase sediment transport over the entire range of flows measured. The data presented in Figure 11 were obtained from one sampling gauge and represent a range of flows between 7,000 and 80,000 cfs obtained between 1983 and 1986, a period of high, transient flood conditions (see Section 2.1.1). On the basis of the regression results presented by the Bureau of Reclamation (U.S. Department of the Interior 1991a), the transported sediment is roughly proportional to the 3.5th power of discharge (Q). That is,

$$
\text { Sediment load (tons/day) }=7.524 \times 10^{-7} \times Q\left(\mathrm{~m}^{3} / \mathrm{s}\right)^{3.53} \text {. }
$$

As with all sediment-load curves, the curves in Figures 11 and 12 have associated variance, as indicated by the scatter of the data points in Figure 11. Actual sediment loads at the Grand Canyon gauge may therefore differ substanilially from those predicted by the regressed data; near the maximum recommended flow, the scatter in observed values ranges over about two orders of magnitude. Some of the factors contributing to this variability are discussed in Section 2.1.2. 


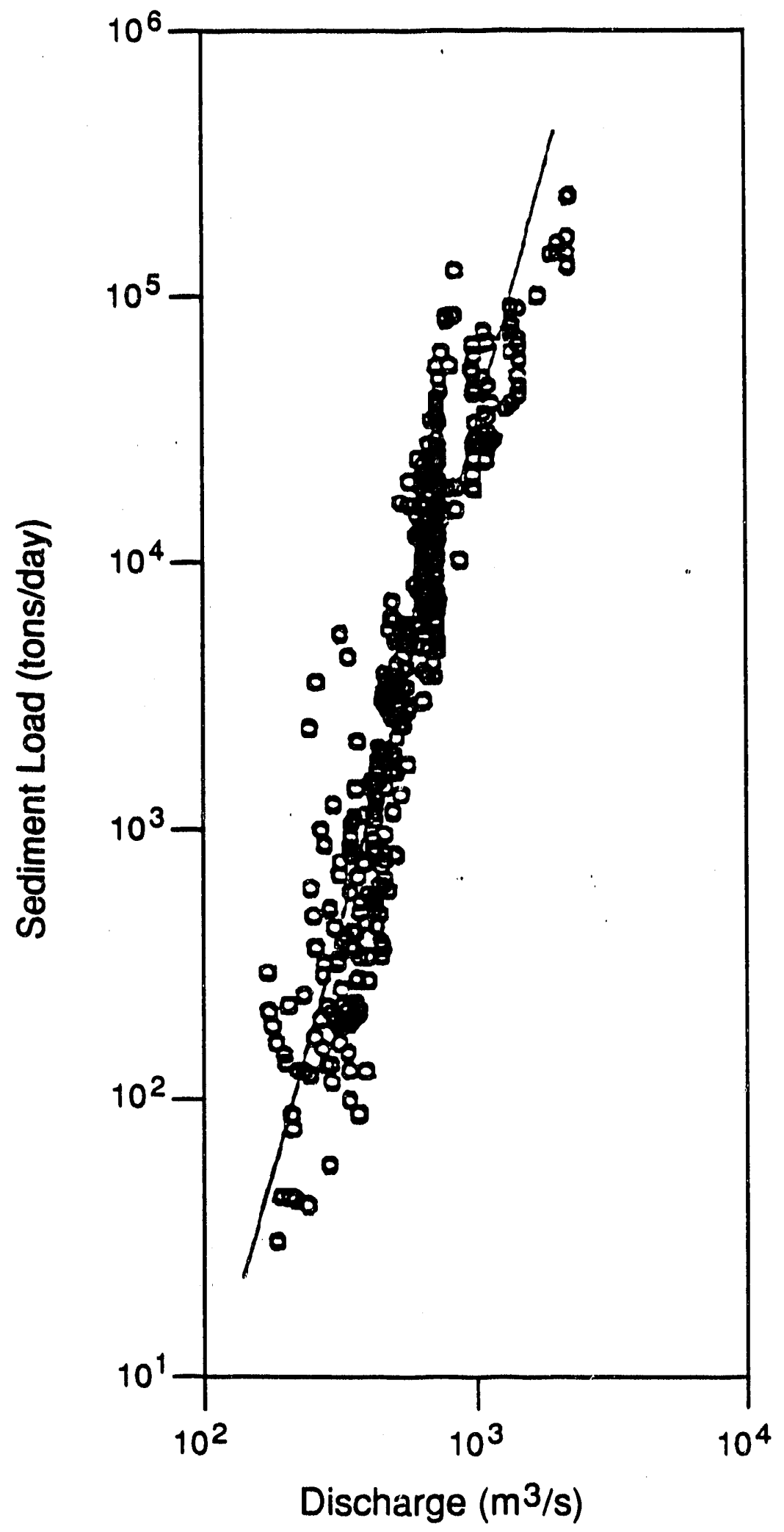

FIGURE 11 Sediment Transported (tons per day) by Various Discharges at the Grand Canyon Gauge, 1983-1986 $\left(R^{2}=0.88\right)$ (Source: U.S. Department of the Interior 1991b) 


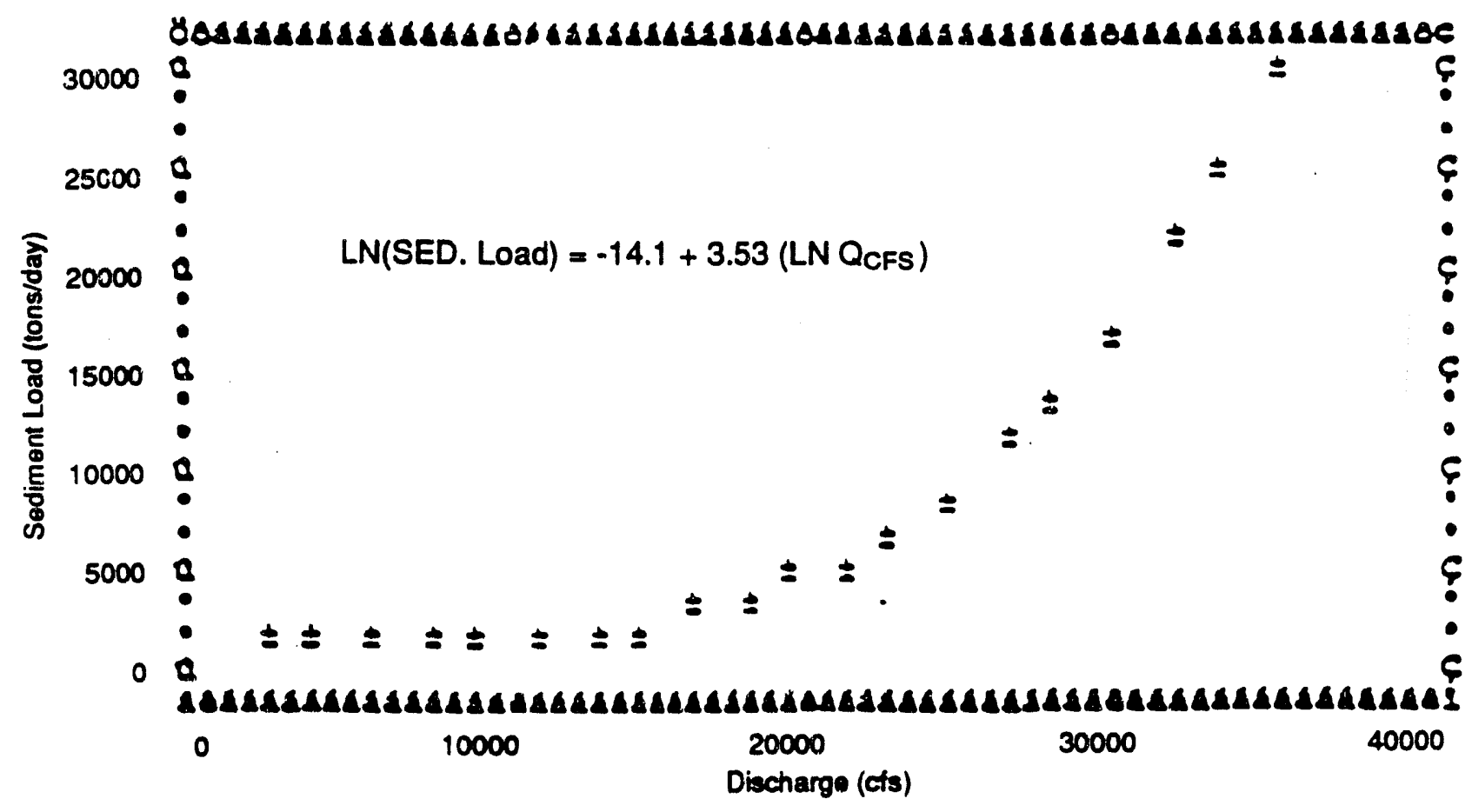

FIGURE 12 Daily Sediment-Load Transport as a Function of Discharge (data taken from regression curve calculated in Figure 11) (Source: U.S. Department of the Intcrior 1991b)

In addition, the sediment-load curve used by the R/S Group in developing the proposed maximum flow is based on sampling done at only one location and, thus, may not be representative of the entire system. Similar studies reported by Pemberton $(1987,1988)$ indicate that sediment transport in the Colorado River is spatially dependent. This spatial dependence is illustrated in Figure 13 for gauges at Lees Ferry, Little Colorado River, and Grand Canyon. Although the slopes of the sediment-load curves are about the same, the sediment-transport rate of the river at the gauge locations is different. For example, the sediment load predicted at the Little Colorado River for a discharge of 20,000 cfs is about $50 \%$ of that measured at Grand Canyon, while that predicted at Lees Ferry is only about 5\% of that at Grand Canyon because of armoring (Section 2.1.3). Sediment loads in different river reaches will, therefore, be affected differently by changing operational releases; armored reaches may withstand higher releases without significant adverse impacts.

Figure 14 compares the sediment-load curve (Equation 1) developed for the Grand Canyon gauge (McQuivey 1991a) and load curves developed by Pemberton (1987) for gauges at Lees Ferry and the Little Colorado River. The sediment-load curve for Lees Ferry was obtained by plotting the relationship given by Pemberton (1987) in Figure 15:

$$
\text { Sediment load (tons/day) }=0.21029 \times 10^{-11} \times \mathrm{Q}(\mathrm{cfs})^{3.3326} \text {. }
$$




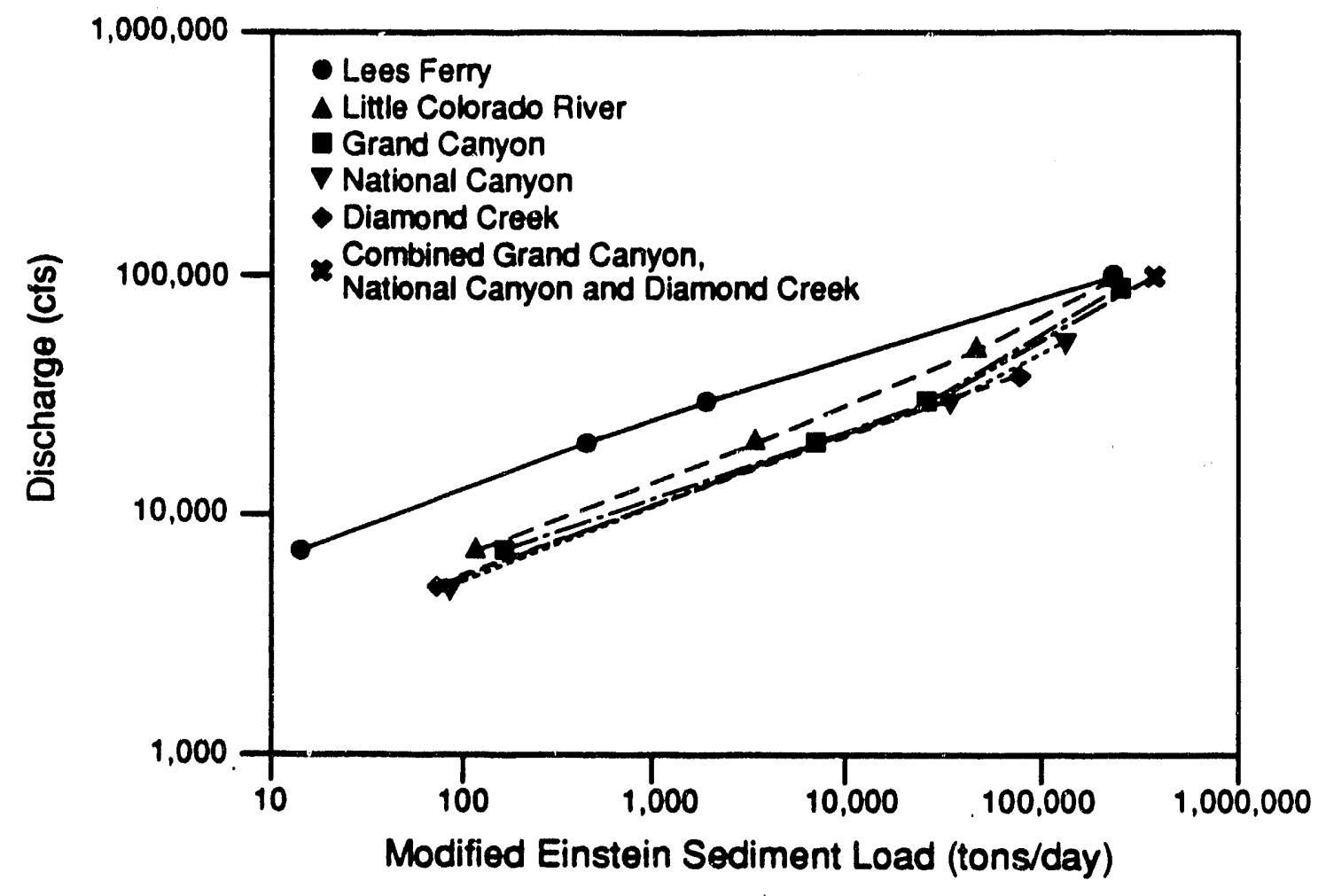

FIGURE 13 Modified Einstein Sediment-Load Rating Curves for the Colorado River in the Grand Canyon (Source: Pemberton 1988)

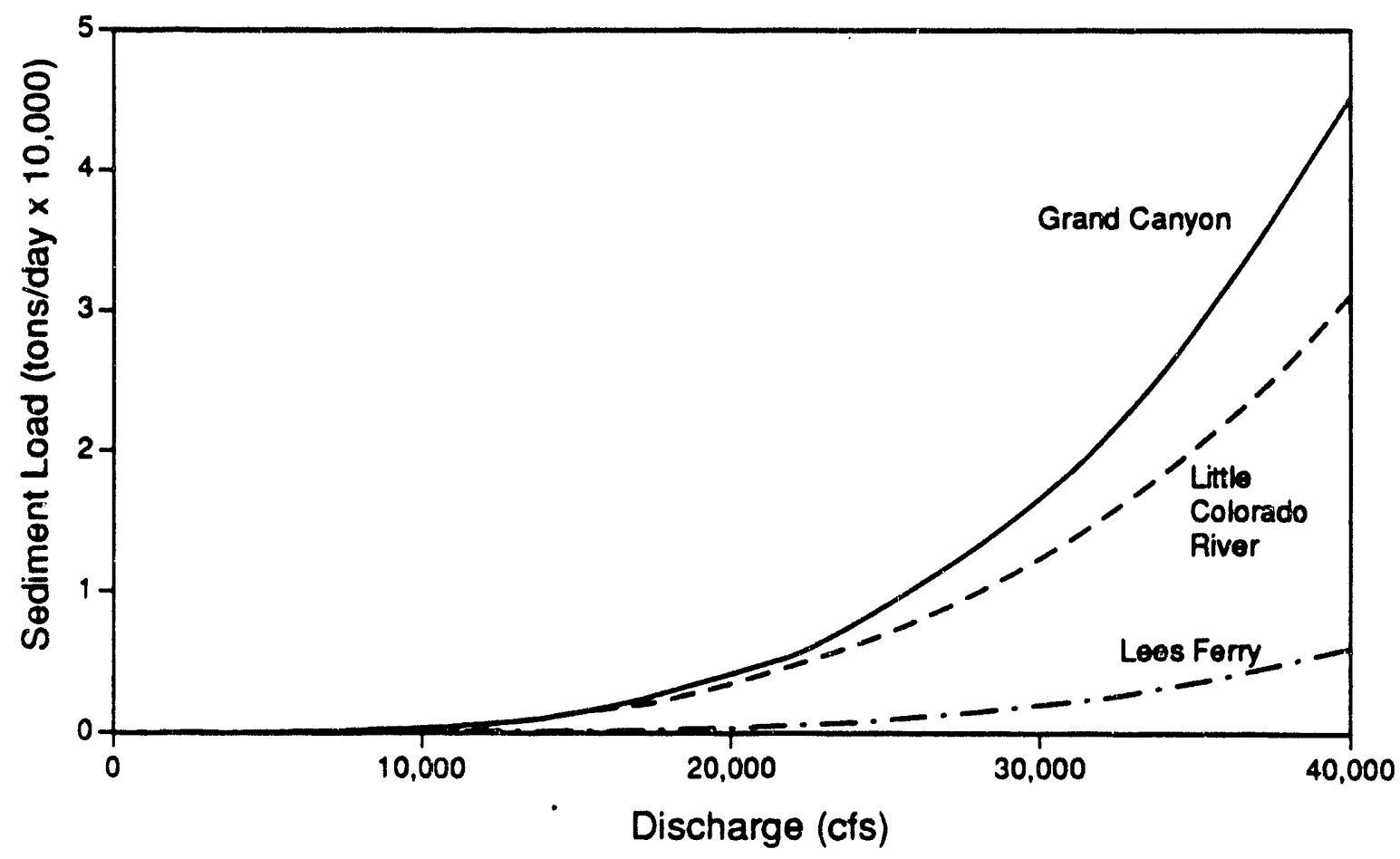

FIGURE 14 Sediment Load as a Function of Discharge at Lees Ferry, Little Colorado River, and Grand Canyon (curves plotted from Equations 1-3 in Section 3.1.1) 


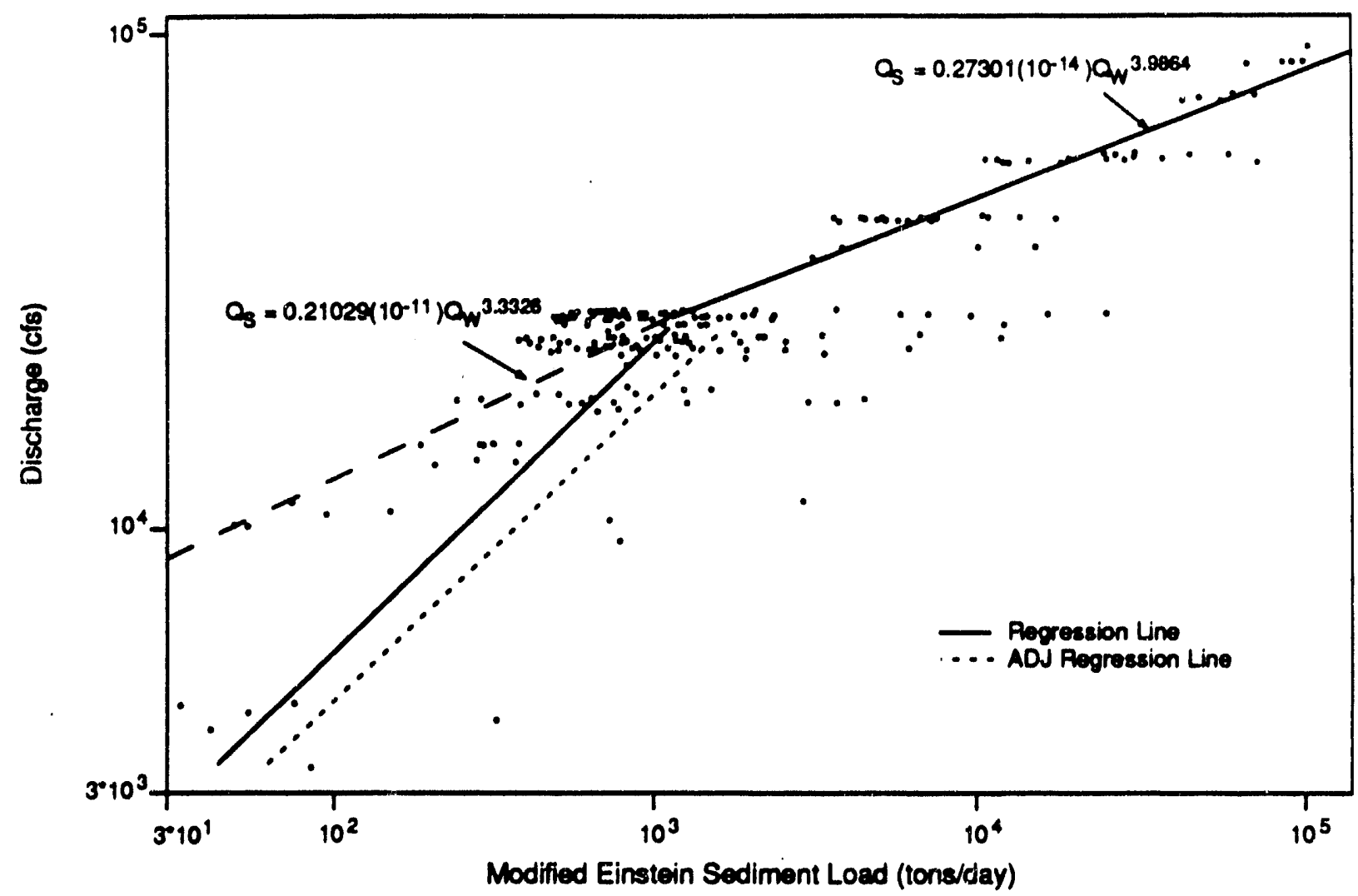

FIGURE 15 Modified Einstein Sediment-Load Rating Curves for the Colorado River at Lees Ferry (Source: Pemberton 1987)

Similarly, the sediment-load curve for the river upstream of the confluence of the Little Colorado River was obtained by plotting the relationship given by Pemberton (1987) in Figure 16:

Sediment load (tons/day) $=0.46047 \times 10^{-10} \times \mathrm{Q}(\mathrm{cfs})^{3.2228}$.

Comparison of the Grand Canyon sediment-load curve plotted in Figure 14 with that shown in Figure 12 indicates that the suggested break in the curve near a flow of 20,000 cfs (discussed in McQuivey 1991a) is mostly an artifact of using a low-resolution, raster-limited printer plot. For a power function, there are no threshold values for sediment transport, and sediment load will increase nonlinearly with increasing discharge for any initial flow value. If one assumes that the slope of the sediment-load curve at $20,000 \mathrm{cfs}$ is a criterion for transport, corresponding flows for the Little Colorado River and Lees Ferry can be found by locating the points on their curves that have the same value of slope. For the Little Colorado River, the equivalent flow is about $25,000 \mathrm{cfs}$, while that at Lees Ferry exceeds $40,000 \mathrm{cfs}$. From Glen Canyon Dam to Lees Ferry, a reach without any major tributaries (Section 2.1.2), maximum releases within current operational constraints will have little impact on remaining sediments, and the 20,000 -cfs maximum will do little to change the sediment load 


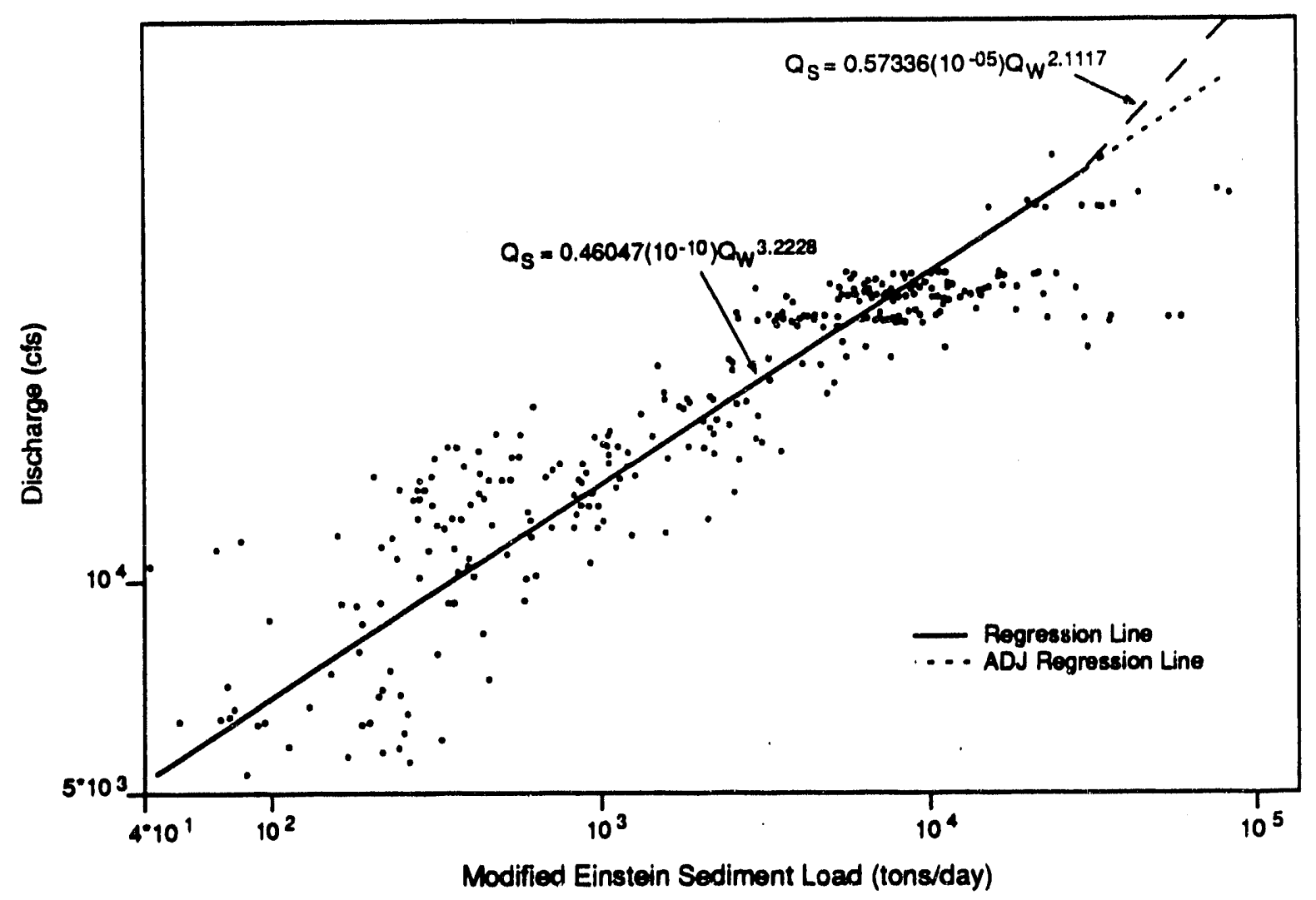

FIGURE 16 Modified Einstein Sediment-Load Rating Curves for the Colorado River above Little Colorado River (Source: Pemberton 1987)

in this reach. Between the Paria and Little Colorado rivers, a reach of particular concern identified by the U.S. Department of the Interior (1991a), an increase in flow of about $20 \%$ would be required to transport the same amount of sediment.

Downstream of Phantom Ranch, the river sediment more closely approaches equilibrium because of the inflow of sediment from tributaries (about 2.9 million tons/year from the Little Colorado River, Paria River, and Kanab Creek). In this reach of the Colorado River, the 1983 flood did not cause significant beach erosion (Carothers and Brown 1991), and impacts associated with the normal maximum release of $31,500 \mathrm{cfs}$ would be small.

As indicated above, higher releases will, in general, produce greater sediment loads in the Colorado River. Historically, high-water releases have been associated with wet years (Section 2.1.1). Because Lake Powell currently is drawn down about 70 feet (lake elevation of about 3,630 feet) or about 9.6 million acre-feet short of a full reservoir, the probability of filling the reservoir over the next three years is estimated to be about 35\% (U.S. Department of the Interior 1991b). The estimated volumetric releases for each of the next three years should, therefore, be about 8.23 million acre-feet, and the monthly release for Glen Canyon Dam should follow a schedule similar to that shown in Figure 17. For an average water year, the average hourly release from Glen Canyon Dam would be about 11,243 cfs (see Figure 18). 


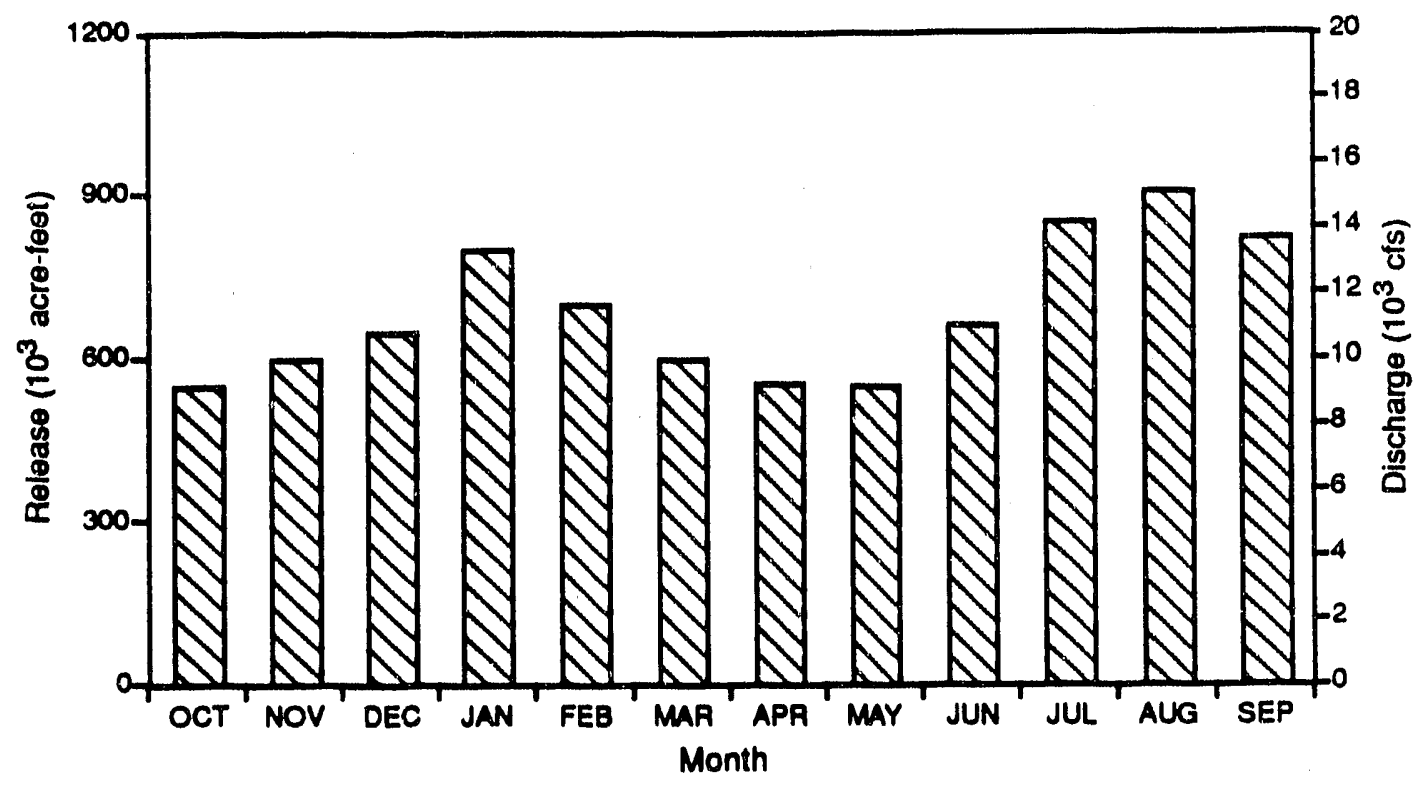

FIGURE 17 Glen Canyon Dam Monthly Releases (Source: U.S. Department of the Interior 1991a)

The probability of exceeding the proposed maximum flow rate of $20,000 \mathrm{cfs}$ is less than $10 \%$. That : $:$, for normal operations, flows would be within the proposed guideline $90 \%$ of the time without the imposed limitation.

Erosion is a function of sediment availability as well as of flow. In the unlikely event that sediment is not delivered to the Colorado River by any of the tributaries for a prolonged period, most of the fine sediment stored in the riverine corridor would be removed from the system. Given average sediment input from tributaries, the reach from the Little Colorado River down to the Grand Canyon gauge will aggrade for flows of less than 24,000 cfs (U.S. Department of the Interior 1991a). Although preliminary analyses discussed by Patten (U.S. Department of the Interior 1991a) indicate that generally less sediment will be removed from the system above the Little Colorado River than is replaced by the Paria River, there is no guarantee that the mean sediment inputs will be achieved (data and analyses are not currently available). Because there is no assurance of sediment input from the Paria during the interim flow period, the R/S Group recommended that discharges at the dam be low enough to prevent sediment loss from the channel in the reach between the Paria and Little Colorado rivers.

The amount of sediment either added to or removed from the system can be estimated hy combining sediment-load curves for various reaches of the Colorado River (Figure 14) with data on sediment delivery by the Paria River to the Colorado River for the years 1945 through 1975 (Figure 19). For conservative results, the gauge at Grand Canyon was used in these calculations. Figure 19 indicates that the mean sediment delivery by the Paria River to the Colorado River is about 800,000 tons/year; the median value is about 500,000 tons/year. The probability of exceeding the mean value is about $40 \%$, while the probability of exceeding the median value is, by definition, 50\%. If it is assumed that the 


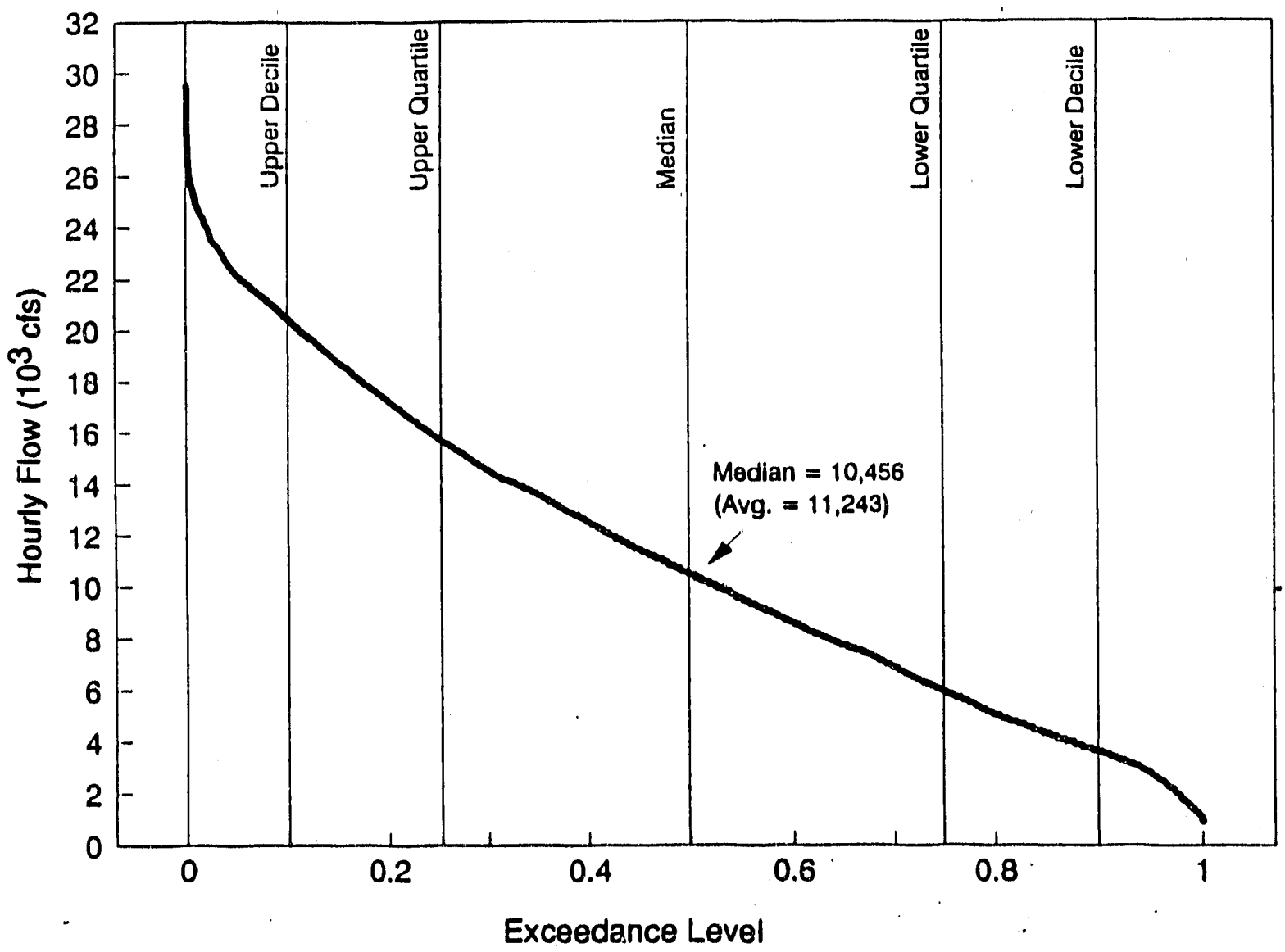

FIGURE 18 Hourly Total Releases at Glen Canyon Dam, Flow Duration for Water Year 1982 (Source: U.S. Department of the Interior 1990)

interim flow period will consist of low-water years ( 8.25 million acre-feet) because of the current state of Lake Powell drawdown and that releases would follow a pattern similar to that of 1982 , flows exceeding $20,000 \mathrm{cfs}$ would occur less than $10 \%$ of the time, while flows exceeding $31,500 \mathrm{cfs}$ would occur much less often (approximately $2 \%$ of the time). For a daily schedule of releases with a maximum release of $20,000 \mathrm{cfs}$ for 2.4 hours, $3,000 \mathrm{cfs}$ for 6 hours, and $13,200 \mathrm{cfs}$ for 15.6 hours, the amount of sediment passing the Grand Canyon gauge is estimated to be about 400,000 tons/year. This amount of sediment would be delivered by the Paria River more than $70 \%$ of the time, and over the interim flow period the stretch between Glen Canyon Dam and the Grand Canyon gauge would probably aggrade.

If the peak flow was increased to $31,500 \mathrm{cfs}$ for $2 \%$ of the time $(0.5$ hour/day $)$, the minimum flow was kept at 3,000 cfs for 6 hours/day, and the remaining flow was at $13,718 \mathrm{cfs}$ for 17.5 hours, the sediment load passing the Grand Canyon gauge would increase to about 470,000 tons/year. The Paria River would be expected to exceed this value about $50 \%$ of the time, and a net sediment equilibrium would be achieved. For the sake of comparison, a steady flow of $11,387 \mathrm{cfs}$ for the year would result in a sediment load of about 200,000 tons/year, which is exceeded by the Paria River more than $85 \%$ of the time. Thus, the Paria River would be expected to deliver an adequate supply of sediment to the Colorado 

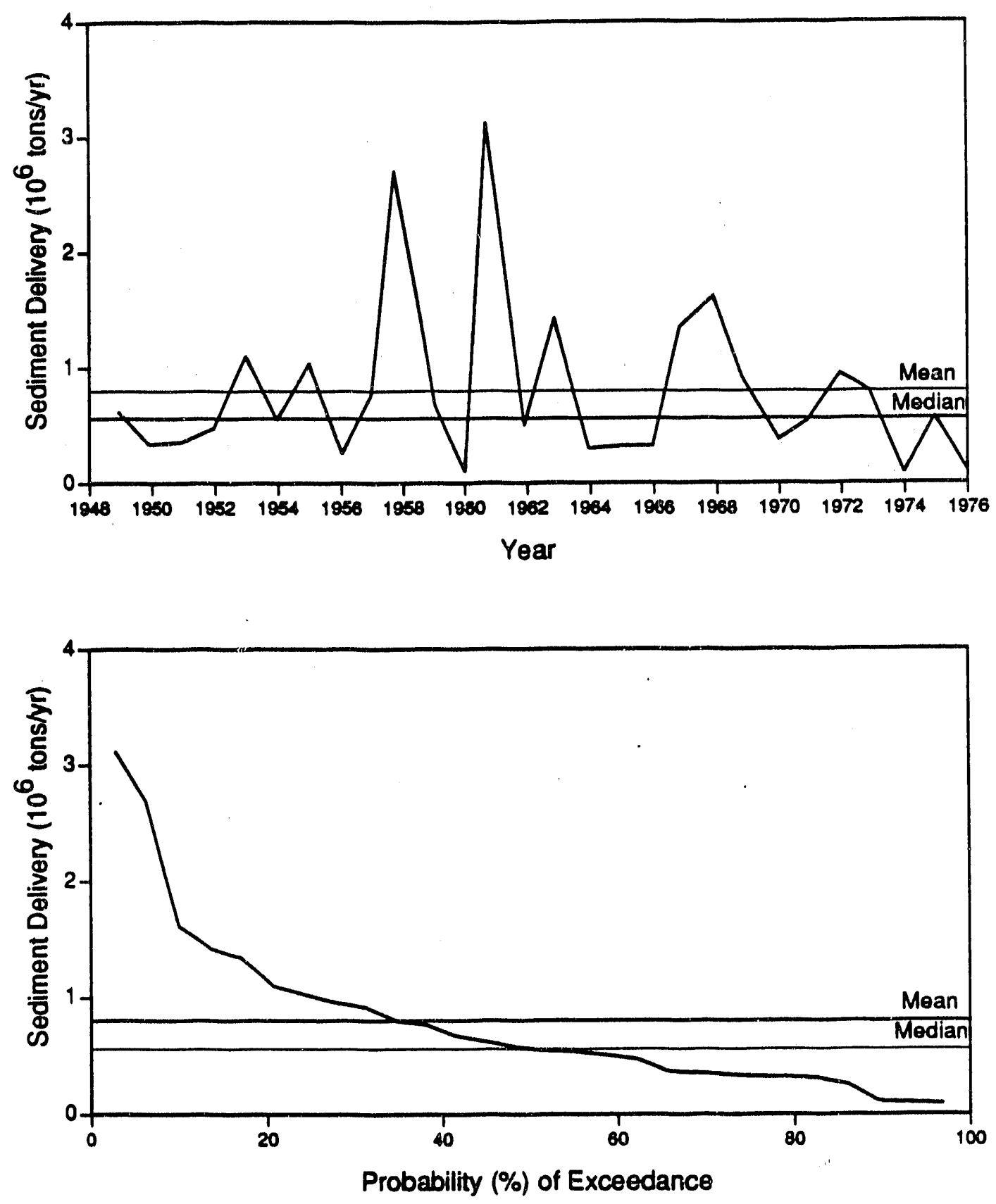

FIGURE 19 Sediment Delivery from the Paria River into the Colorado River, 1948-1975 (Source: U.S. Department of the Interior 1991b) 
River, precluding significant adverse hydrologic impacts, even under historic operating conditions. To reduce the uncertainties in these calculations, additional information on the Paria River and the results of new and expanded studies of sediment measurements in the Colorado River reaches of concern are needed. These results should be available from Phase II of the GCES; however, they were not available for this report.

Although erosion is recognized to be a function of flow, location, material properties, and time, the sediment-load curves developed by the Bureau of Reclamation (U.S. Department of the Interior 1991a) only estimate steady state transport processes at a given location; temporal variations are not addressed. This omission is particularly important when considering the time frame of the interim flow period (three years) and the nonequilibrium dynamics of the river system. For example, sediments deposited during the 1983 flood were neither consolidated nor stabilized by vegetation and, therefore, are more susceptible to erosion. Although studies were developed to investigate transient system behavior during Phase II of the GCES, the results were not available for this report.

In summary, the proposed maximum flow of $20,000 \mathrm{cfs}$ is a conservative choice to halt degradation of downstream hydrological resources. Because of uncertainties in the data and methodologies used to develop sediment-load curves, however, the maximum flow criterion is probably overly conservative, especially for the interim flow period in which transient effects are important.

As indicated by the U.S. Department of the Interior (1991a), aggradation of the reach below the Paria River will occur for releases of $24,000 \mathrm{cfs}$ or less, provided the suspended sediment load in the Paria River is nearly normal. Consequently, with proposed interim operating criteria, most of the area below Glen Canyon Dam is expected to accumulate sediments. Without higher flows, main-channel scour holes will fill, channel margin deposits will increase, gravel beds will fill with finer sediments, and new and existing debris flows will experience diminished scour and redistribution. These conditions will continue until a flood redistributes the sediments along the riverine corridor.

As discussed above, yearly releases during the interim period are expected to average about 8.23 million acre-feet. For this discharge, the probability of equaling or exceeding the maximum power-generation capability of $31,500 \mathrm{cfs}$ is small (less than about $2 \%$ of the time). In the reach between the dam and Lees Ferry, a release of $31,500 \mathrm{cfs}$ will have no significant effect on the deposits because of past armoring of the channel in 1965 and 1983. Between Lees Ferry and the Little Colorado River, a flow of $31,500 \mathrm{cfs}$ will have only a small effect, especially if the sediment load in the Paria River is near the median value. Below Phantom Ranch, the maximum power discharge will have no significant effect on the river sediments because of sediment loads from tributaries and debris flows.

As mentioned previously, GCES Phase I results are associated primarily with flood conditions in the riverine corridor. Extrapolation to lower, but strongly fluctuating, flows and prediction of short-term transient effects are speculative and not founded on good scientific analyses and supportable data. On the basis of data and analyses in Phase I, it is unlikely that irreversible effects would be imposed on the abiotic resources in the short term. At the 
proposed maximum flow criterion, sediment aggradation rather than erosion might occur in the reach below the Little Colorado River.

\subsubsection{Aquatic Ecology}

No aquatic biological resources were targeted for protection under any of the proposed interim maximum releases (U.S. Department of the Interior 1991a). Inundation of backwaters at flows above the proposed $20,000 \mathrm{cfs}$ could cause some secondary impacts on aquatic biota. Maddux et al. (1987) reported fewer backwaters present at 28,000 cfs than at $4,800 \mathrm{cfs}$, which suggests that backwater abundance decreases with increasing flow. However, with the exception of the backwaters identified at flows of $28,000 \mathrm{cfs}$ and $4,800 \mathrm{cfs}$, there is no information regarding backwater abundance and distribution at other flows.

Backwater dynamics are affected by flow, channel morphology, and river stage. For example, Pucherelli et al. (1990) examined the relationships between flow and backwater number, size, and area (Figure 20) in the Green River, Utah. They found backwater number, size, and total area to either (1) gradually increase with increasing flow, (2) dramatically increase over a relatively small increase in flow, or (3) dramatically decrease with increasing flow, depending on the location within the river. The nature of the relationships reflects sitespecific channel morphology and river-stage differences among the sites. Because of the complex relationships among these factors and backwater dynamics, no effort should be made to predict the amount of backwaters that may be present at a flow of $20,000 \mathrm{cfs}$ (or any other flow) solely from backwater availability at flows of $28,000 \mathrm{cfs}$ and $4,800 \mathrm{cfs}$.

Because of the importance of the mouth of the Little Colorado River as a nursery area for the humpback chub, the GCES Phase I final report (U.S. Department of the Interior 1988) suggested a late spring and early summer flow of $31,500 \mathrm{cfs}$ to maintain a lotic environment at the mouth of that river. The recommendation to protect this lotic environment is warranted given the importance of this area to the federally endangered humpback chub. It is not known whether such an environment would be maintained at a maximum flow of $20,000 \mathrm{cfs}$.

\subsubsection{Riparian Ecology}

Currently, riparian biological resources (other than marshes) have become established above the 31,500-cfs level, the historic maximum discharge rate. Although these resources are not directly affected by maximum releases, they could be adversely affected by erosion of the sediment deposits that serve as substrates for vegetation. Proposed interim operating criteria included a lower maximum release rate in part to reduce the erosion of elevated sediment deposits that serve as substrates for riparian plants (U.S. Department of the Interior 1991a). The relationship between sediment transport and discharge in the Colorado River was used to justify the suggested maximum release rate of 20,000 çfs from 

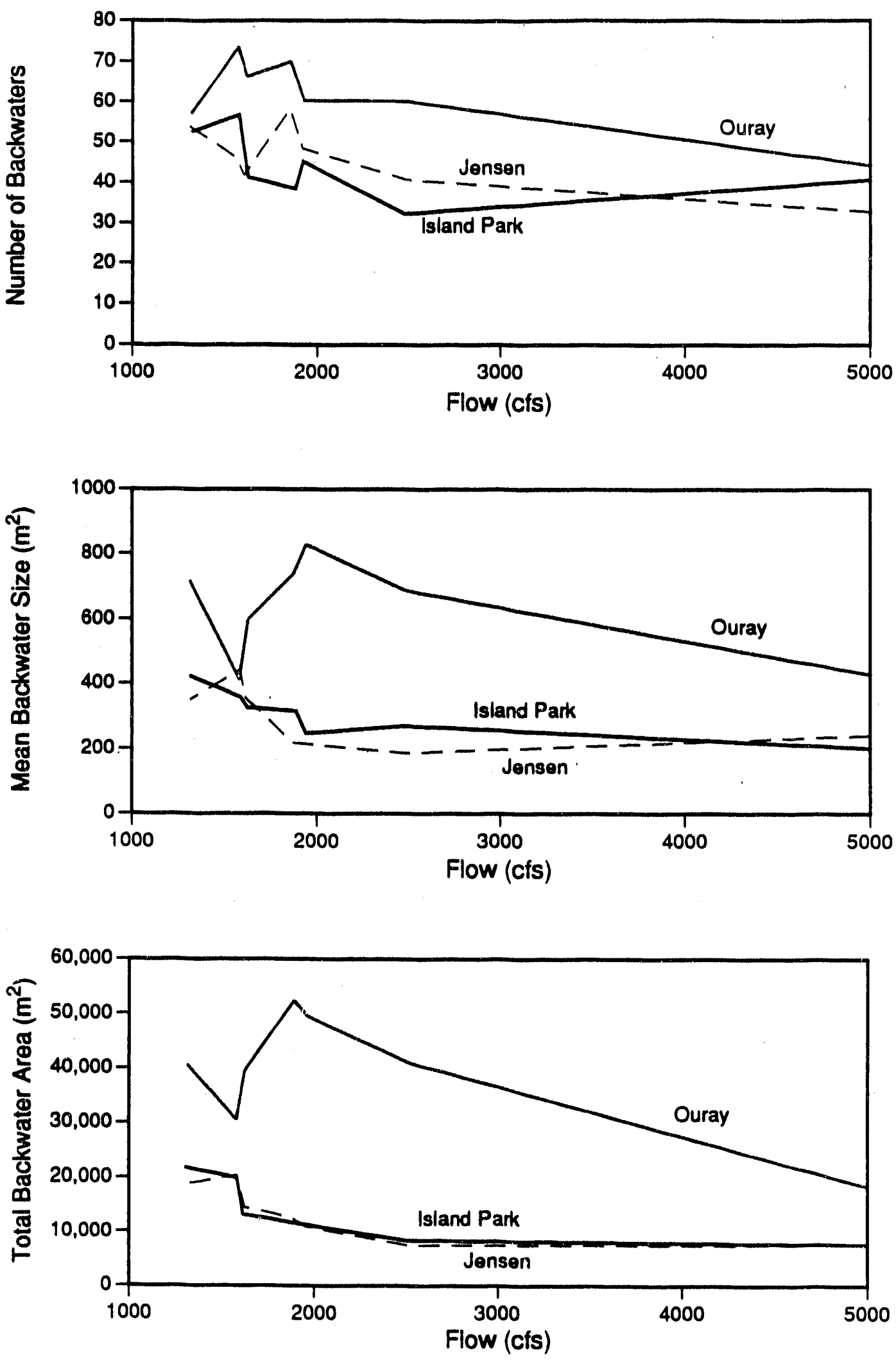

FIGURE 20 Relationship between Flow and Availability of Backwater Habitat at Three Locations in the Green River, Utah (Source: Pucherelli et al. 1990) 
Glen Canyon Dam (see Section 3.1.1 for a discussion of this relationship). In addition, it was argued that reductions in maximum discharge could make sites at lower elevations available for colonization of new high-water zone vegetation and result in an eventual shift of this community downward (U.S. Department of the Interior 1991a; Carothers and Brown 1991).

The effects of dam-induced erosion on riparian plant communities below Glen Canyon Dam have not been studied. Phase I studies indicated that changes occurred to elevated sediment deposits that were formed during the 1983 flood (Schmidt and Graf 1988). Most of these sites experienced net erosion of sediment, but this erosion was attributed to fluctuating flows rather than to flow rate per se. Such newly formed deposits would be unstable until colonized by vegetation, but eventually should reach equilibrium with an established flow regime. Topographic surveys in the 1970 s indicated that such an equilibrium had been reached with the altered flow regime below the dam (Section 2.1.3) (Schmidt and Graf 1988).

With adoption of the proposed maximum release, expansion of the riparian plant community down to the 20,000-cfs level would be likely, but the current upper extent of this community eventually could be lost because of the reduced soil moisture at higher elevations resulting from lower water levels. Therefore, an increase in riparian vegetation might not be possible over the long term.

A reduction in maximum releases could affect riparian biological resources adversely by making these resources more susceptible to natural flood events. As discussed in Section 2.3, riparian resources were affected adversely by floods from 1983 to 1986 . Brian (1987) estimated that about $49 \%$ of plant cover in the new high-water zone was lost as a result of these floods. The floods also inundated a substantial number of bird nests in the riparian zone (Brown and Johnson 1987). By increasing the availability of habitat below the present high-water line, the proposed operating criteria would encourage the colonization of lower elevations by riparian biota and thus make these resources more vulnerable to smaller floods, even those in the range of historic operations.

\subsection{MINIMUM FLOW}

\subsubsection{Hydrology}

The proposed minimum water releases range from 5,000 to $8,000 \mathrm{cfs}$ (Table 1 ). These flows were selected in part to minimize the amount of time a beach would be exposed to draining conditions and a steeper hydraulic gradient that could accelerate beach-face wasting (U.S. Department of the Interior 1991a; McQuivey 1991b) and to minimize large ramp rates associated with large daily changes in flow. No Phase I results support the selection of the minimum water release proposed. During Pliase II of the GCES, information was to be gathered and analyzed to investigate the effects of this process. However, at the time of this study, those results were not available. 
Under current operating conditions, the minimum flow is 1,000 cfs (Table 1), which is $4,000 \mathrm{cfs}$ less than the minimum flow recommended in the proposals. No evidence in any of the Phase I data or analyses indicates that a 4,000-cfs difference in minimum flows would affect downstream sediment deposits irreversibly.

\subsubsection{Aquatic Ecology}

The aquatic biological resources identified for protection under the three sets of proposed interim minimum flows were similar. These resources are the humpback chub and native fishes, trout, and the aquatic food base.

The primary concerns for the humpback chub and native fishes involved the potential loss of backwater nursery areas (U.S. Department of the Interior 1991a). Low flows can result in the loss of backwater habitats through dewatering. The R/S Group and test flows identified 5,000 cfs as a minimum flow to provide adequate backwaters, while the E/RM proposal stated that the stability and abundance of backwaters would be greater with a minimum discharge of $8,000 \mathrm{cfs}$.

Backwater habitats are used as nursery areas by native fishes and the humpback chub in the Colorado River below Glen Canyon Dam, and available information clearly shows that more backwaters are present at a low flow of $4,800 \mathrm{cfs}$ than at a high flow of more than $20,000 \mathrm{cfs}$ (Maddux et al. 1987). However, the numbers and distribution of backwater habitats have not been evaluated at lower flows. Past dam operations (before 1983) included low flows between 1,000 and 3,000 cfs, and native fish populations appear to have remained healthy. This result may be due in part to the importance of tributaries as nursery areas for the native fishes, but also could suggest that sufficient backwater nursery areas exist at flows of less than approximately 5,000 cfs. However, no information regarding backwater abundance is available for flows of less than approximately $5,000 \mathrm{cfs}$.

Some backwaters are not completely dewatered during low flows, but instead become cut off from the main channel, which strands fishes in these isolated areas. Fishes trapped in isolated backwaters are probably more susceptible to terrestrial predators and adverse environmental conditions (Maddux et al. 1987). The 8,000-cfs minimum flow recommended by the E/RM Group was thought to reduce backwater isolation by maintaining water in backwater return channels.

Stranding of fishes also was evaluated at flow levels of 4,800 and 28,000 $\mathrm{cfs}$ (Maddux et al. 1987). Although more isolated backwater areas were present at low flows than at high flows, the significance of the stranding that occurred was not determined. A majority of fishes stranded in isolated backwaters were of introduced species that may compete with or consume native fishes and rainbow trout. Although predation of stranded fishes could have resulted in a significant underestimate of fish-stranding, the possible magnitude of such predation was not estimated. 
A simple linear relationship may not exist between flows and backwater characteristics (see Section 3.1.2). Pucherelli et al. (1990) studied backwater-flow relationships in the Green River, Utah, and their data indicate a complex relationship between flows and backwater habitats (Figure 20) that is tied directly to river morphology. Without further investigation of backwater-flow relationships in the Colorado River below Glen Canyon Dam, it is not possible to select a minimum flow that will maximize backwater habitat.

Adult trout are sometimes stranded over spawning substrates such as cobble bars. Approximately 800 trout were reported stranded after a reduction in flow from 24,000 cfs to $5,000 \mathrm{cfs}$ (Maddux et al. 1987). However, this study evaluated trout stranding only once, over a three-day period following the 19,000-cfs change in flow. Under these conditions, the study does not differentiate between the effect of minimum flow and the effect of the sharp drop in flow experienced over this time period. Stranding has not been evaluated for other flows or conditions, but occasional public reports of trout stranding have been received by the Arizona Department of Game and Fish. These reports typically occurred after low flows of $1,000 \mathrm{cfs}$ (Maddux et al. 1987), and estimates of stranding have ranged from approximately 20 to 100 trout. The fact that lower estimates of stranding are associated with flows lower than experimental flows suggests that other factors, such as the ramp rate and the magnitude of the stage change, may affect stranding.

Low flows also have been implicated in the dewatering of trout redds abive Lees Ferry (U.S. Department of the Interior 1991a). Studies on experimental redds located below the dam found that dewatering for as little as an hour significantly increased egg and alevin mortality (Maddux et al. 1987). Although more cobble bars that contain redds may be exposed under low flows, their relative abundance was only evaluated for two flows, 4,800 cf.s and 28,000 cfs (Maddux et al. 1987), and the exposed cobble bars were not sampled for the presence of trout redds. Neither of these studies provided the information needed to identify a particular minimum flow that would be protective of trout eggs and young.

Impacts on the aquatic food base result primarily from exposure of benthic biota after a decrease in stage, and the magnitude of the impact depends on the amount of river bottom exposed and the duration of that exposure. The data of Usher et al. (1987) show that the Cladophora standing crop was strongly affected by extended periods of exposure and desiccation, and the data support limiting the duration of the minimum flow period to no more than six to eight hours. In addition, impacts of exposure were greater during the day when air temperature was higher. The Cladophora beds that were most affected by exposure and desiccation were those established within three feet of the average high-water line. Impacts to benthic organisms and to Cladophora and its associated biota occur primarily in an "intertidal" zone, which represents the area between the average daily high- and low-water lines along the shoreline (Carothers and Brown 1991). The biota in this area thus are more affected by the daily change in water flows and the resultant stage changes than by the minimum flow alone. This intertidal zone will become established on the basis of whatever minimum and maximum flows are released from the dam. 


\subsubsection{Riparian Ecology}

Riparian resources were not considered a target resource for recommended minimum releases (U.S. Department of the Interior 1991b). Because of their occurrence above the highwater line, these resources should not be affected either directly or indirectly by minimum flows.

\subsection{MAXIMUM DAIIY FLUCTUATION}

\subsubsection{Hydrology}

A daily change (fluctuation) in flow of not more than 5,000 cfs has been proposed (Table 1). This constraint is suggested in order to minimize beach erosion due to changing water releases that averaged about $13,220 \mathrm{cfs} / \mathrm{d}$ for 1966 through 1989 (U.S. Department of the Interior 1990) and that resulted in a water-level change of 13 feet in the Grand Canyon area when the daily change in flow reached a maximum value of $30,500 \mathrm{cfs}$ (U.S. Department of the Interior 1991a). As discussed in Section 3.1.1, sediment-transport modeling was performed under Phase I of the GCES with currently available models and data; more complete information and analyses are scheduled for Phase II. Preliminary modeling done under Phase I indicates that the amount of sediment stored in the main-channel bed of the Colorado River would decrease about $12 \%$ for fluctuating flow conditions (normal power operation range) and an annual release of 8.2 million acre-feet (Randle and Pemberton 1987). Erosion would be increased at higher daily water releases, but in the short term the effects would be small and probably reversible.

Some preliminary results of Phase II studies provided by Patten (U.S. Department of the Interior 1991a) indicate that beach erosion increases as the daily change in stage goes above one meter. This stage change has been associated with a 5,000-cfs/d change in release. However, as indicated by the studies of Peterson and MacNish (U.S. Department of the Interior 1991a), the stage-discharge relationship is spatially dependent and nonlinear; a higher flow is required to produce a one-meter change in stage at downstream locations. MacNish recommended daily fluctuations as high as $10,000 \mathrm{cfs}$, while Peterson's recommendations ranged frum 5,000 to $8,000 \mathrm{cfs}$, depending on the wetness of the year. The maximum allowable daily change of release could, therefore, be higher than that proposed by the R/S Group without significant adverse impacts on abiotic resources. Additional results of these analyses are not currently available.

\subsubsection{Aquatic Ecology}

The R/S Group focused on beach and bank erosion in proposing a limit on maximum daily fluctuation (U.S. Department of the Interior 1991a), but identified all canyon attributes as being affected by daily fluctuations. The R/S Group also stated that the ability of Cladophora to withstand flow stress decreased as the range of daily change increased. The 
E/RM Group agreed with the R/S proposal and, thus, targeted the same aquatic biological resources for protection (U.S. Department of the Interior 1991a). The maximum daily fluctuation specified in the test flows was targeted at reducing impacts on fishes associated with spawning, stranding, and backwater areas (U.S. Department of the Interior 1991a).

Daily fluctuations in flow are thought to affect the humpback chub and native fishes by alternately draining and filling nursery backwater areas, altering sand bar dynamics that determine backwater characteristics, and limiting access to creek mouths during the spawning season. Fluctuating flows in backwater nursery areas are thought to force young fishes into the main channel of the Colorado River, where they may be more susceptible to predation and expend energy at a higher rate. Daily fluctuations are also considered to modify trout habitats and lead to the stranding of trout adults, larvae, and eggs.

Different maximum daily changes in flow have not been evaluated for their potential impacts on backwater distribution, abundance, and stability. Although data are available regarding the presence of backwaters at flows of approximately 28,000 and $4,800 \mathrm{cfs}$ (Section 3.2.2), backwater dynamics have not been investigated at different daily changes in flow.

Maddux et al. (1987) evaluated backwater habitat use during fluctuating flows in three river reaches. Fluctuations ranging from 20,160 to $21,500 \mathrm{cfs}$ were maintained in these reaches for a period of seven consecutive days in the fall of 1985 . Fish abundance, except for rainbow trout, in backwaters also did not differ significantly between steady and fluctuating flows. The abundance of rainbow trout in backwaters was significantly decreased under fluctuating flows, but the importance of this decrease to population dynamics was not evaluated. No significant difference was found in backwater temperature between steady and fluctuating flows in any of the river reaches. Although the study by Maddux et al. (1987) established a potential effect of fluctuating flows on backwater use, it has limited applicability to establishing interim criteria because more than one range of flows was not tested.

Because the study of backwater use was conducted in the fall, no larval fishes were present in the system and, therefore, their use of these habitats could not be tested. The energy costs of moving between the backwater and main-channel habitats during fluctuating flows has not been evaluated for either larvae or older fishes. Similarly, the susceptibility to predation of young fishes moving into main-channel environments during fluctuating flows has not been evaluated. Thus, consideration of potential impacts from predation and increased energy costs in the development of the proposed maximum daily flow fluctuations ar? not supported by any existing data.

Studies of stranding of fishes are discussed above in the evaluations of the proposed minimum flows (Section 3.2.2). These investigations did not evaluate stranding under different daily fluctuations, but rather looked at stranding after reductions in flow from 28,000 to 4,800 cfs. Maddux et al. (1987) sampled fishes from isolated backwaters created during fluctuating flows ranging from 20,160 to $21,500 \mathrm{cfs}$. Because of the relatively short duration of the sampling and the absence of any specific pattern in stranding, it is difficult to draw any conclusions about how daily fluctuations of approximately $20,000 \mathrm{cfs}$ affect 
stranding of fishes in backwaters. Stranding under different ranges of daily fluctuations has not been evaluated.

The R/S Group stated that substantial daily fluctuations make creek mouths less accessible to native fishes during spawning but provide no discussion or references to support this conclusion (U.S. Department of the Interior 1991a). Maddux et al. (1987) made such a statement, however, and this source may be the basis for the R/S proposal. Maddux et al. reported that Nankoweap Creek was not accessible to rainbow trout after a long period of fluctuating flows and that four major tributaries could be isolated during periods of low flows in the main channel, with concurrent low flows in the tributaries magnifying this isolation. They then suggested that prolonged periods of fluctuating flows would affect spawning success adversely. However, no evidence was provided to support the statement that fluctuating flows were responsible for the isolation of Nankoweap Creek or the potential isolation of the other four creeks. Nankoweap Creek was isolated because of a combination of low main-channel flows and the presence of a gravel bar barrier that had formed as a result of outflow from the creek itself (Maddux et al. 1987). The potential isolation of the four other creeks identified by Maddux et al. (1987) was attributed by those authors to low flows.

The effects of fluctuating flows on Cladophora and epiphytes were evaluated by Usher et al. (1987) and Leibfried and Blinn (1987). The annual growth pattern for Cladophora glomerata in both lotic and lentic systems has been reported to include seasonal peaks in growth in spring and autumn (Usher et al. 1987). Seasonal cycles in abundance and diversity, with peaks in spring and autumn, have also been observed in epiphytes in a number of aquatic systems (Usher et al. 1987). Measured standing crops of Cladophora were lower in winter following a period of fluctuating flows than they were in autumn during steady flows (Usher et al. 1987). These reductions in standing crop were attributed to the effects of fluctuating flows but may also reflect, at least in part, natural seasonal growth cycles.

One reason to limit the maximum daily fluctuation in dam discharge is to minimize the amount of benthic substrate and its resident biota that would experience periods of dewatering and desiccation (U.S. Department of the Interior 1991a). As daily dam releases fluctuate between low and high flows, the river stage fluctuates. As a result, a zone of shoreline substrate is submerged at high flows but is dewatered and exposed to desiccation at low flows (Section 3.2.2).

The amount of Cladophora downstream increased dramatically after closure of Glen Canyon Dam. This increase has been attributed to favorable combinations of temperature, water clarity, and alkalinity (Carothers and Brown 1991). During this period of increase, the maximum daily fluctuation in discharge from Glen Canyon Dam was 30,500 cfs. These fluctuations resulted in stage changes of greater than 8-10 feet at most locations downstream of the dam (U.S. Department of Interior 1991a).

Usher et al. (1987) evaluated the effects of fluctuating flows of about 20,000 cfs on Cladophora growing at depths from just below the surface to four feet and reported 
significant reductions in standing crop at depths up to three feet. The authors attributed these reductions in biomass primarily to desiccation while Cladophora was exposed during flow fluctuations. Thus, it appears that the effects of fluctuation on Cladophora biomass is more a function of the duration and timing of exposure than the magnitude of the fluctuations.

The proposed maximum daily fluctuations $(5,000-8,000 \mathrm{cfs})$ would limit river stage changes to about three feet (U.S. Department of the Interior 1991a). One rationale for this proposed limitation is that the ability of Cladophora to withstand flow stress is decreased by wider fluctuations (U.S. Department of the Interior 1991a). However, the impacts to Cladophora appear to result primarily from the length of exposure, not from flow fluctuations themselves. Reducing fluctuations to the proposed level will not necessarily change the amount of time that Cladophora within the intertidal zone is exposed (which is dependent upon other aspects of dam operations), although it may reduce somewhat the depth of the zone that is exposed on a daily basis. However, the zone in which Usher et al. (1987) found the most impact to Cladophora beds (up to three feet in depth) could still be affected under stage changes resulting from the proposed fluctuations. The exact nature of stage changes and the area of Cladophora beds exposed during fluctuations are difficult to predict, because these depend largely on riverbed morphology and the initial stage of the river.

\subsubsection{Riparian Ecology}

Riparian biota were thought to be affected indirectly by maximum daily fluctuations (U.S. Department of the Interior 1991a). Adverse effects were tied to the accelerated erosion of elevated deposits and leaching of nutrients that are expected to result from fluctuating flows.

Riparian plant communities are not directly affected by daily fluctuations, because these communities are located above the area of fluctuating flows. The effects of fluctuating flows on riparian biological resources below Glen Canyon Dam have not been examined, and little basis exists for selecting a particular limit on maximum daily fluctuation relative to potential impacts to these resources. Although it is clear that erosion accelerates with increases in flow fluctuation, there is some suggestion that equilibrium is eventually reached with any set of flows. Such an equilibrium for post-dam flows was apparent below the dam in the late 1970s before Lake Powell filled (Schmidt and Graf 1988). Subsequent floods have caused the formation of relatively unstable sand deposits, but equilibrium should be reachieved after a renewal of fluctuating flows (Schmidt and Graf 1988). Evidence was obtained for leaching of nutrients from soils that were inundated for extended periods during floods (Stevens and Waring 1986), but it is unclear what effect, if any, daily fluctuations have on nutrient levels above the area of fluctuating flows. 


\subsection{RAMP RATES}

\subsubsection{Hydrology}

The R/S and E/RM groups recommended up- and down-ramp rates of 2,000 and $1,000 \mathrm{cfs} / \mathrm{h}$, respectively (Table 1 ). Test flows were set at an up-ramp rate of $8,000 \mathrm{cfs}$ per four hours and a down-ramp rate of $1,500 \mathrm{cfs} / \mathrm{h}$. As with the previously discussed constraints, these guidelines were recommended to minimize beach and sediment erosion. No scientific basis for either number exists in the results of the Phase I studies, although there is qualitative evidence that high ramp rates increase the rate of erosion. The recommended down-ramp rate proposed by the $\mathrm{R} / \mathrm{S}$ Group is an extrapolation below the minimum research ramp rate of $3,600 \mathrm{cfs} / \mathrm{h}$ studied during Phase II of the GCES.

Under historical operations, the up- and down-ramp rates were not limited (Table 1). During the interim period, low runoff is anticipated, and the annual release is expected to be about 8.23 million acre-feet. Under such conditions, maximum flows greater than 20,000 cfs will occur less than $10 \%$ of the time, and the maximum daily change will be less than 19,000 cfs. For a low runoff year (e.g., 1989), the mean ramp rate was less than $2,300 \mathrm{cfs} / \mathrm{h}$, and the maximum ramp rate did not reach the $19,000 \mathrm{cfs} / \mathrm{h}$ value. Although these rates are higher than those proposed for interim operating criteria, and higher rates of erosion will occur downstream of the dam, it is unlikely that the sediment deposits will be affected irreversibly in the short term.

\subsubsection{Aquatic Ecology}

No aquatic biological resources were targeted for protection under any of the proposed interim up-ramp rates (U.S. Department of the Interior 1991a). Some impacts to adult and juvenile fishes may occur as a result of very rapid inundation of warm nursery areas and tributary mouths with cold main-channel water, resulting in thermal shock to some fish. No aquatic biological resources were targeted for protection under the down-ramp rates proposed by the R/S and E/RM groups (U.S. Department of the Interior 1991a). The test flow maximum down-ramp rate of $1,500 \mathrm{cfs} / \mathrm{h}$ was targeted to reduce potential impacts of rapidly declining waters on spawning trout and to reduce the likelihood that native fishes would be stranded in backwaters.

It is reasonable to assume that fishes may become stranded more readily by rapidly receding water levels than by slowly receding waters. Different down-ramp rates were not evaluated in terms of their potential effect on stranding of fishes, however, and little basis exists for identifying a rate of $1,500 \mathrm{cfs} / \mathrm{h}$ as being protective of native fishes and trout. The stranding of native fishes in backwater habitats was evaluated by determining the number of isolated backwaters present at a single high flow (28,000 cfs) and a single low flow $(4,800 \mathrm{cfs})$ (Section 3.2.2). The ramp rates during these investigations were not reported, and the data were not evaluated with regard to ramp rates (Maddux et al. 1987). 
Stranding of trout above Lees Ferry was evaluated following a decrease in flow from about $24,000 \mathrm{cfs}$ to $5,000 \mathrm{cfs}$ over a period of about 16 hours. During that time, the downramp rate averaged about $1,200 \mathrm{cfs} / \mathrm{h}$ (Figure 21) and had a maximum rate of $2,540 \mathrm{cfs} / \mathrm{h}$ for a 30-minute period (Maddux et al. 1987). However, the frequency and magnitude of trout stranding at different ramp rates are unknown.

With the variability in the down-ramp rate reported during the study by Maddux et al. (1987) and the absence of stranding information for other ramp rates, it is not possible to identify any single down-ramp rate to prevent stranding. Although stranding impacts may be reduced at some down-ramp rate, there is no quantitative basis for specifying the proposed down-ramp rate to reduce the stranding of fishes.

\subsubsection{Riparian Ecology}

Riparian biota are thought to be affected indirectly by up- and down-ramp rates (U.S. Department of the Interior 1991a). Potential adverse effects are linked to the accelerated erosion rates of elevated deposits and leaching of nutrients that are expected to result from ramping events. Riparian biota are not affected directly by ramp rates because these resources are located above the area of fluctuating flows. The effects of ramp rates on these resources have not been examined, and there is little basis for selecting a particular set of ramp rates. The discussion in Section 3.3.3 on the effects of daily flow fluctuations on riparian biological resources also applies to the effects of ramp rates.

\subsection{BEACH-BUILDING FLOW}

\subsubsection{Hydrology}

The R/S and E/RM groups suggested a beach-building flow of $31,500 \mathrm{cfs}$, with a duration of 6 to 14 days. Historical measurements indicate that flood discharges from Glen Canyon Dam, such as those of 1965 and 1983, can build new elevated deposits along the riverine corridor provided that sufficient sediment load is in the river to prevent scour (U.S. Department of the Interior 1988). If it is assumed that river stage changes about one foot for each 2,500 cfs, sediments would be built up to a level about four feet higher than deposits resulting from the proposed maximum operating release of 20,000 cfs.

Data in the Phase I GCES indicate that releases of $31,500 \mathrm{cfs}$ or higher could be sustained without significant adverse impacts in the river reach between the dam and Lees Ferry and between Lees Ferry and the Little Colorado River, provided the sediment load in the Paria River was nearly normal. Downstream of the Phantom Ranch, a flood release of $31,500 \mathrm{cfs}$ should have little impact on the abiotic resources. With proper timing (i.e., high sediment load in the river), beach-building flows could produce new elevated deposits in the Grand Canyon area. 


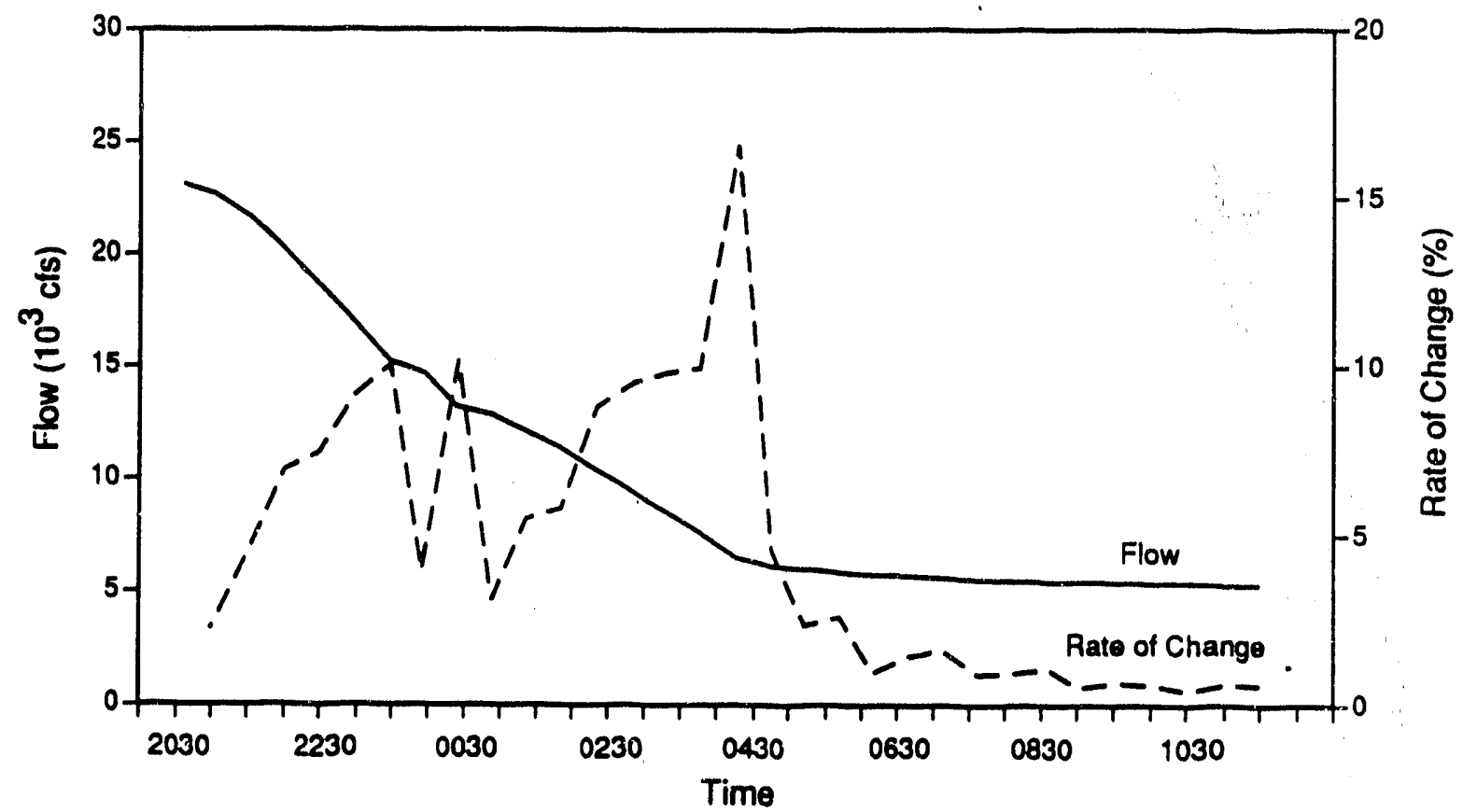

FIGURE 21 Instantaneous Flow and Rates of Change in Flow in the Colorado River during Trout-Stranding Studies (Source: Maddux et al. 1987)

\subsubsection{Aquatic Ecology}

The flows recommended for spring beach-building are intended to affect biological aquatic resources in at least two ways (U.S. Department of the Interior 1991a). It is thought that the spawning activities and movements of humpback chub and some of the other native fishes are cued in part by high flows. The high flows also are intended to enhance the habitat quality of backwaters by flushing sediments and debris from these areas.

The conclusion that high flow, by itself, would cue spawning activities of humpback chub or other native fishes is not well supported. Although some studies have attempted to relate the timing of humpback chub spawning activities to high flow (Karp and Tyus 1990), photoperiod, temperature, or other factors may be equally or even more important to the timing of reproduction. It seems reasonable that high spring flows could remove some of the silt and debris within backwater areas; however, the magnitude of flow needed to accomplish this removal is not known.

\subsubsection{Riparian Ecology}

Beach-building flows of $31,500 \mathrm{cfs}$ were proposed as a means to store sediments above the area of fluctuating flows and thus reduce the net transport of sediments out of the study area and to provide substrates for riparian plants (U.S. Department of the Interior 1991a). It was suggested that these flows be timed to prevent the enhancement of exotic plant species, but specific recommendations on this timing were not provided. 
Proposed beach-building flows, while meant to imitate the effects of natural flood events, would be well below the typical flood flow (approximately 90,000 cfs). The proposed flow is the same as the historical maximum operating flow of $31,500 \mathrm{cfs}$. It is this level that has established the lowermost extent of the new high-water zone riparian community. Although such a flow would serve to deposit sediments above the proposed new normal operating maximum of $20,000 \mathrm{cfs}$, it would fall short of that needed to maintain the old highwater zone plant community $(90,000 \mathrm{cfs})$. In addition, these sediments would not be above the level of most natural floods (again 90,000 cfs), which will occur more frequently if Lake Powell fills. On the basis of these considerations, the recommended beach-building floods would serve little purpose in the long-term storage of sediments and support of riparian vegetation. 


\section{CONCLUSIONS}

The scientific bases of three sets of proposed interim operating criteria (R/S, E/RM, and test criteria) designed to protect natural environmental resources below Glen Canyon Dam were evaluated on the basis of information available from Phase I of the Glen Canyon Environmental Studies (GCES) and other data sources. Several questions were addressed to evaluate the merit of proposed operating criteria. Because the three sets of proposed criteria were very similar, the results of the evaluation of each are essentially the same. The following discussion addresses each question.

Question 1: Are the natural resources that are the focus of the proposed interim operating criteria those that are potentially affected by dam operations, and would those resources be irreversibly affected by dam operations in the short term?

For all proposed interim operating criteria, the resources that potentially are affected by dam operations were correctly identified, and the proposed operating criteria focus on relevant operational parameters. These operational parameters included maximum and minimum flow rates, up- and down-ramp rates, and inaximum daily fluctuations. The resources potentially affected by dam operations included stream flow, sediment transport, beach erosion, threatened and endangered fishes, trout, the aquatic food base, and riparian plant communities (Table 2). Available studies indicate it is unlikely that any of the downstream riverine resources examined would be irreversibly affected by current dam operations in the three-year period when interim operating criteria would be implemented.

Question 2: Are the methodologies used to develop the proposed interim operating criteria objective and scientifically based, and are the available data unambiguous and sufficient to recommend interim operating criteria?

The proposed operational criteria were, for the most part, based on incomplete data and analyses even though state-of-the-art techniques often were employed in developing specific proposed operating criteria. Ongoing studies in Phase II of the GCES may eliminate many of the deficiencies but could lead to different preferred operating parameters. One of the biggest problems with the applicability of Phase I data to interim operating criteria was that the data were collected during flood flows that probably are not representative of the Colorado River system under normal operating conditions. Extrapolation of the results of Phase I to significantly different flow regimes introduces sufficient uncertainty into the results so as to preclude the selection of operating criteria based primarily on those results.

Question 3: Are the proposed operating criteria supportable on the basis of available data?

Phase I of the GCES was not intended to be a formal study for developing flow criteria. That fact is apparent in many of the ecological studies that either focused only on the effects of the 1983 flood or compared a single high-flow condition with a single low flow condition. Although these types of data and analyses were useful in identifying adverse 
impacts at high flows, they do not allow identification of a particular set of flow conditions that would be protective of environmental resources. This finding is similar to the conclusions of the National Academy of Sciences (1987) report, which found the GCES Phase I studies to be incomplete and led to the recommendation for continued research and analyses in Phase II of the project.

The constraints of the interim operating criteria are generally conservative and focus on reducing erosion a 1 transport of sediments out of the river reach between the Paria and Little Colorado rivers. All of the proposed operating criteria would reduce the amount of sediment lost from this river reach. Limiting the maximum flow to $20,000 \mathrm{cfs}$ probably would halt degradation of the downstream abiotic resources and result in a net sediment aggradation below the confluence with the Paria River. Although the operating criteria are generally conservative, an extrapolation below the minimum research flow was used to develop all three proposed interim criteria for down ramping.

Question 4: Are there alternatives to the proposed operating criteria that would be as protective of the environmental resources as the proposed interim operating criteria, on the basis of available GCES information?

As stated above, the proposed operating criteria are conservative and focus on reducing erosion and sediment transport. To be as protective of downstream sediment deposits as the proposed interim operating criteria, any alternative would, by definition, have to be as conservative. That is, maximum flows would have to be $20,000 \mathrm{cfs}$ or less, minimum flows no less than $5,000 \mathrm{cfs}$, daily changes less than about 5,000 cfs, and ramp rates less than 2,000 and $1,000 \mathrm{cfs} / \mathrm{h}$ for up- and down-ramp rates, respectively. In the case of maximum allowable discharge, an evaluation of results presented by Pemberton (1987) (Section 3.1.1) indicates that a maximum release of about $25,000 \mathrm{cfs}$ would not significantly affect the downstream sediment deposits. Because the relationships between other flow characteristics and natural resources are not well known, conservative alternatives to the proposed minimum flows, ramp rates, and maximum daily fluctuations cannot be formulated at this time.

Because the proposed interim operating criteria emphasize reduced erosion in the riverine system, potential adverse impacts of the interim criteria were not thoroughly evaluated. The proposed reductions in maximum flow to $20,000 \mathrm{cfs}$ would result in a shift of the riparian zone to lower levels and would make plant and animal populations in this zone more vulnerable to the large floods that will periodically occur. A net gain in riparian habitat as suggested by the U.S. Department of the Interior (1991a) is not likely to occur, because under the reduced maximum flows, the upper extent of the new high-water zone would move down in elevation. Such reductions in flow may also allow a greater accumulation of debris at tributary mouths and reduce the accessibility of these tributaries to fishes at low flows. The proposed minimum flow may not maximize backwater habitats, because the relationship between flow and habitat is related to channel morphology and will therefore vary among different river reaches. Backwater availability in the entire study area under different flow regimes needs to be examined to determine optimal low flows. The 
proposed beach-building floods, which are essentially sustained historical maximum operating flows, will fall far short of the flows needed to mimic natural flood events and to sustain resources that potentially are dependent on those events (e.g., spawning of native fishes and the old high-water zone riparian plant community). These flows may be useful in reducing *transport of sediments during average flow years but may not remove the debris that accumulates at tributary mouths as a result of reduced flows. Periodic natural or planned floods that mimic natural floods (e.g., 60,000-90,000 cfs) would be needed to accomplish this goal. Sediments would need to be deposited at higher elevations so that the old high-water zone plant community could be sustained. 


\section{REFERENCES}

Anderson, L.S., and G.A. Ruffner, 1987, Effects of the Post-Glen Canyon Dam Flow Regime on the Old High Water Line Plant Community along the Colorado River in Grand Canyon, Glen Canyon Environmental Studies Technical Report, Bureau of Reclamation, Salt Lake City, Utah.

Bestgen, K.R., 1990, Status Review of the Razorback Sucker, Xyrauchen texanus, Colorado State University Larval Fish Laboratory, Colorado State University, Fort Collins, Colo., Contribution 44, prepared for the Bureau of Reclamation, Upper Colorado Regional Office, Salt Lake City, Utah.

Blinn, D.W., and G.A. Cole, 1991, Algal and Invertebrate Biota in the Colorado River: Comparison of Pre- and Post-Dam Conditions, in Colorado River Ecology and Dam Management, Symp. Proc., National Academy Press, Washington D.C., pp. 102-123.

Brian, N.J., 1987, Aerial Photography Comparison of 1983 High Flow Impacts to Vegetation at Eight Colorado River Beaches, Glen Canyon Environmental Studies Technical Report, Bureau of Reclamation, Salt Lake City, Utah.

Brown, B.T., and R.R. Johnson, 1987, Fluctuating Flows from Glen Canyon Dam and Their Effect on Breeding Birds of the Colorado River, Glen Canyon Environmental Studies Technical Report, Bureau of Reclamation, Salt Lake City, Utah.

Burkham, D.E., 1988, Trends in Selected Hydraulic Variables for the Colorado River at Lees Ferry and near Grand Canyon, Arizona, 1922-1984, Glen Canyon Environmental Studies, Executive Summaries of Technical Reports, Bureau of Reclamation, Salt Lake City, Utah.

Carothers, S.W., and B.T. Brown, 1991, The Colorado River through Grand Canyon Natural History and Human Change, University of Arizona Press, Tucson.

Colby, B.R., and C.H. Hembree, 1955, Computations of Total Sediment Discharge, Niobrara River near Cody, Nebraska, U.S. Geological Survey Water-Supply Paper 1357, Washington, D.C.

Ferrari, R., 1988, Sandy Beach Area Survey along the Colorado River in the Grand Canyon National Park, Glen Canyon Environmental Studies, Executive Summaries of Technical Reports, Bureau of Reclamation, Salt Lake City, Utah.

Howard, A., and R. Dolan, 1981, Geomorphology of the Colorado River in the Grand Canyon, Journal of Geology 89:269-298.

Johnson, R.R., 1991, Historic Changes in Vegetation along the Colorado River in the Grand Canyon, in Colorado River Ecology and Dam Management, Symp. Proc., National Academy Press, Washington, D.C., pp. 178-206. 
Karp, C.A., and H.M. Tyus, 1990, Humpback Chub (Gila cypha) in the Yampa and Green Rivers, Dinosaur National Monument, with Observations on Roundtail Chub (G. robusta) and Other Sympatric Fishes, Great Basin Naturalist 50:257-264.

Kubly, D., 1991, unpublished data presented at the Glen Canyon Environmental Studies Environmental Impact Statement Team Joint Meeting, Flagstaff, Ariz., Oct.

Leibfiied, W.C., and D.W. Blinn, 1987, The Effects of Steady Versus Fluctuating Flows on Aquatic Macroinvertebrates in the Colorado River below Glen Canyon Dam, Arizona, prepared for the Bureau of Reclamation, Upper Colorado Region, Glen Canyon Environmental Studies, Salt Lake City, Utah.

Maddux, H.R., et al., 1987, Evaluation of Varied Flow Regimes on Aquatic Resources of Glen and Grand Canyons, Final Report, prepared for the Bureau of Reclamation, Upper Colorado Region, Glen Canyon Environmental Studies, Salt Lake City, Utah.

McQuivey, L., 1991a, Glen Canyon Dam Interim Operations, letter from L. McQuivey (Bureau of Reclamation, Salt Lake City, Utah) to K. Maxey (Western Area Power Administration, Salt Lake City, Utah), April 10.

McQuivey, L., 1991b, Glen Canyon Dam Interim Operations: Answers to Questions Posed by WAPA, CREDA, and the Upper Colorado River Commission, letter from L. McQuivey (Bureau of Reclamation, Salt Lake City, Utah) to K. Maxey (Western Area Power Administration, Salt Lake City, Utah), April 4.

Minckley, W.L., 1991, Native Fishes of the Grand Canyon Region: An Obituary?, in Colorado River Ecology and Dam Management, Symp. Proc., National Academy Press, Washington, D.C., pp. 124-177.

National Academy of Sciences, 1987, River and Dam Management: A Review of the Bureau of Reclamation's Glen Canyon Environmental Studies, National Academy Press, Washington, D.C.

Orvis, C.J., and T.J. Randle, 1987, Sediment Transport and River Simulation Model, PB88-183413, Glen Canyon Environmental Studies Technical Report, Bureau of Reclamation, Denver, Colo.

Orvis, C.J., and T.J. Randle, 1988, Sediment Transport and River Simulaticn Model, Glen Canyon Environmental Studies, Executive Summaries of Technical Reports, Bureau of Reclamation, Salt Lake City, Utah.

Pemberton, E.L., 1987, Sediment Data Collection and Analysis for Five Stations on the Colorado River from Lees Ferry to Diamond Creek, PB88-183397, Glen Canyon Environmental Studies Technical Report, Bureau of Reclamation, Denver, Colo. 
Pemberton, E.L., 1988, Sediment Data Collection and Analysis for Five Stations on the Colorado River from Lees Ferry to Diamond Creek, Glen Canyon Environmental Studies, Executive Summaries of Technical Reports, Bureau of Reclamation, Salt Lake City, Utah.

Pucherelli, M.J., 1986, Evaluation of Riparian Vegetative Trends in the Grand Canyon Using Multitemporal Remote Sensing Techniques, Glen Canyon Environmental Studies Technical Report, Bureau of Reclamation, Salt Lake City, Utah.

Pucherelli, M.J., et al., 1990, Mapping Backwater Habitat on the Green River as Related to the Operation of Flaming Gorge Dam Using Remote Sensing and GIS, Bureau of Reclamation, Denver, Colo.

Randle, T.J., and E.L. Pemberton, 1987, Results and Analysis of STARS Modeling Efforts of the Colorado River in Grand Canyon, Glen Canyon Environmental Studies Technical Report, Bureau of Reclamation, Salt Lake City, Utah.

Randle, T.J., and E.L. Pemberton, 1988, Results and Analysis of STARS Modeling Efforts of the Colorado River in Grand Canyon, Glen Canyon Environmental Studies, Executive Summaries of Technical Reports, Bureau of Reclamation, Salt Lake City, Utah.

Schmidt, J.C., 1987, Geomorphology of Alluvial Sand Deposits, Colorado River, Grand Canyon National Park, Arizona, Ph.D. Dissertation, The John Hopkins University, Baltimore, Md.

Schmidt, J.C., and J.B. Graf, 1988, Aggradation and Degradation of Alluvial Sand Deposits, 1965 to 1986, Colorado River, Grand Canyon National Park, Arizona, Glen Canyon Environmental Studies, Executive Summaries of Technical Reports, Bureau of Reclamation, Salt Lake City, Utah.

Schmidt, J.C., and J.B. Graf, 1990, Aggradation and Degradation of Alluvial Sand Deposits, 1965 to 1986, Colorado River, Grand Canyon National Park, Arizona, U.S. Geological Survey Professional Paper 1493, Washington, D.C.

Sigler, W.F., and J.W. Sigler, 1987, Fishes of the Great Basin, A Natural History, University of Nevada Press, Reno, Nev.

Stanford, J.A., and J.V. Ward, 1991, Limnology of Lake Powell and the Chemistry of the Colorado River, in Colorado River Ecology and Dam Management, Symp. Proc., National Academy Press, Washington, D.C., pp. 75-101.

Stevens, L.E., and G.L. Waring, 1986, Effects of Post-Dam Flooding on Riparian Substrates, Vegetation, and Invertebrate Populations in the Colorado River Corridor in Grand Canyon, Arizona, Glen Canyon Environmental Studies Technical Report, Bureau of Reclamation, Salt Lake City, Utah.

U.S. Department of the Interior, 1988, Glen Canyon Environmental Studies Final Report, Bureau of Reclamation, Salt Lake City, Utah. 
U.S. Department of the Interior, 1990, Historic Streamflows, Water Releases, and Reservoir Storage for Glen Canyon and Lake Powell, Baseline Reference Data for the Glen Canyon Dam EIS, Bureau of Reclamation, Denver, Colo.

U.S. Department of the Interior, 1991a, Glen Canyon Dam Interim Operating Criteria Supporting Document, Bureau of Reclamation, Denver, Colo.

U.S. Department of the Interior, 1991b, Glen Canyon Dam Interim Operating Criteria, Environmental Assessment, Bureau of Reclamation, Denver, Colo.

U.S. Fish and Wildlife Service, 1990, Humpback Chub Recovery Plan, Denver, Colo.

Usher, H.D., et al., 1987, Cladophora glomerata and Its Diatom Epiphytes in the Colorado River through Glen and Grand Canyons: Distribution and Desiccation Tolerance, prepared for the Bureau of Reclamation, Upper Colorado Region, Glen Canyon Environmental Studies, Salt Lake City, Utah.

Valdez, R.A., 1991, Project summary presented by R.A. Valdez, BIO/WEST, Inc., Logan, Utah, to the National Research Council Glen Canyon Environmental Studies Review, Flagstaff, Ariz., Oct.

Valdez, R.A., and G.H. Clemmer, 1982, Life History and Prospects for Recovery of the Humpback and Bonytail Chub, in Fishes of the Upper Colorado River System: Present and Future, W.H. Miller, H.M. Tyus, and C.A. Carlson, eds., Western Division, American Fisheries Society, Bethesda, Md., pp. 109-119.

Warren, P.L., and C.R. Schwalbe, 1987, Lizards along the Colorado River in Grand Canyon National Park: Possible Effects of Fluctuating River Flows, Glen Canyon Environmental Studies Technical Report, Bureau of Reclamation, Salt Lake City, Utah.

Webb, H.W., 1988, Debris Flows from Tributaries of the Colorado River, Grand Canyon National Park, Arizona, Glen Canyon Environmental Studies, Executive Summaries of Technical Reports, Bureau of Reclamation, Salt Lake City, Utah, Nov.

Webb, R.H., P.T. Pringle, and G.R. Rink, 1987, Debris Flows from Tributaries of the Colorado River in the Grand Canyon National Park, U.S. Geulogical Survey Open-File Report 87-118, Tucson, Ariz., Sept.

Weatherford, G.D., and B. Babbitt, 1986, New Courses for the Colorado River, Major Issues for the Next Century, University of New Mexico Press, Albuquerque, N.M. 

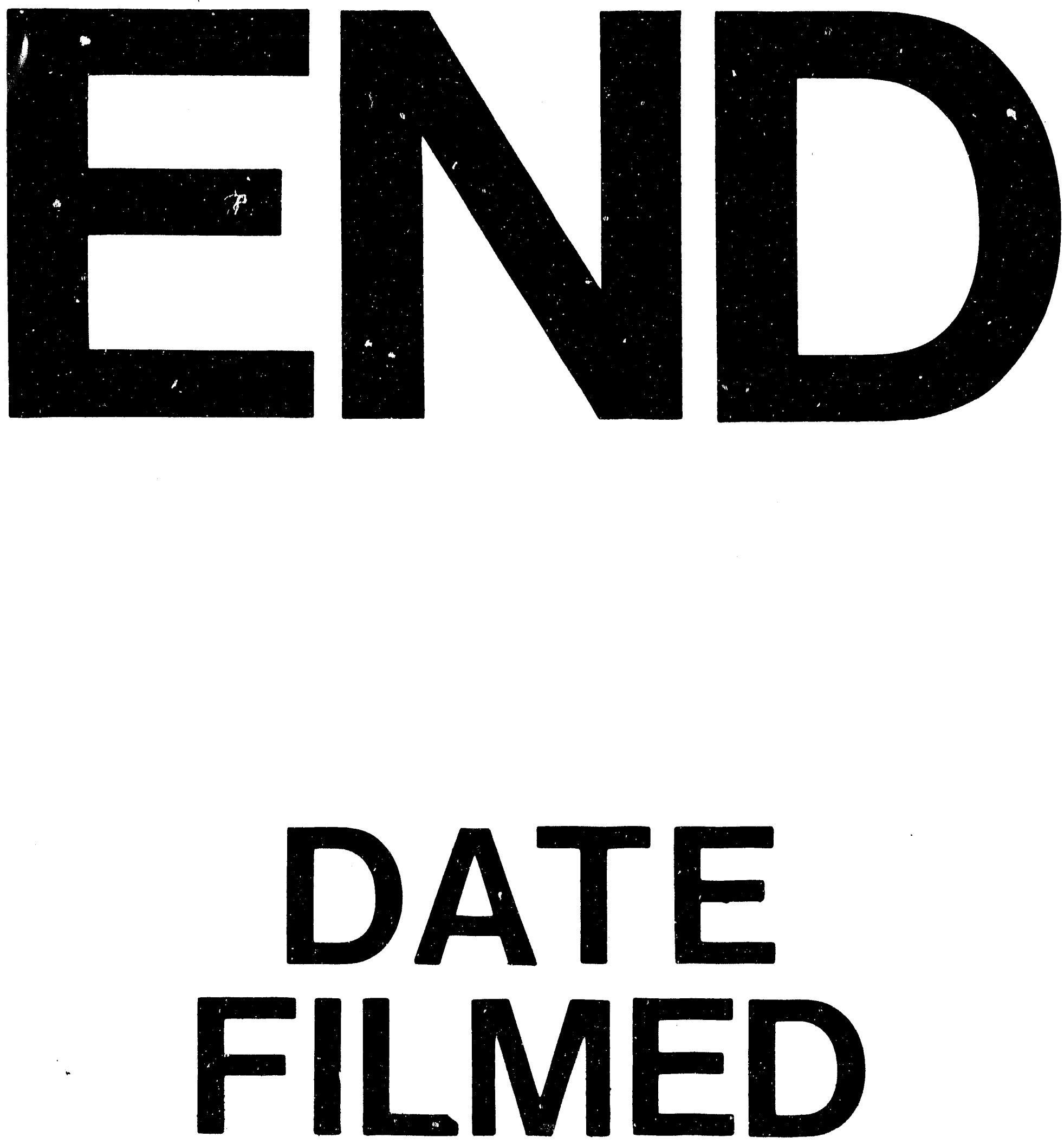

1

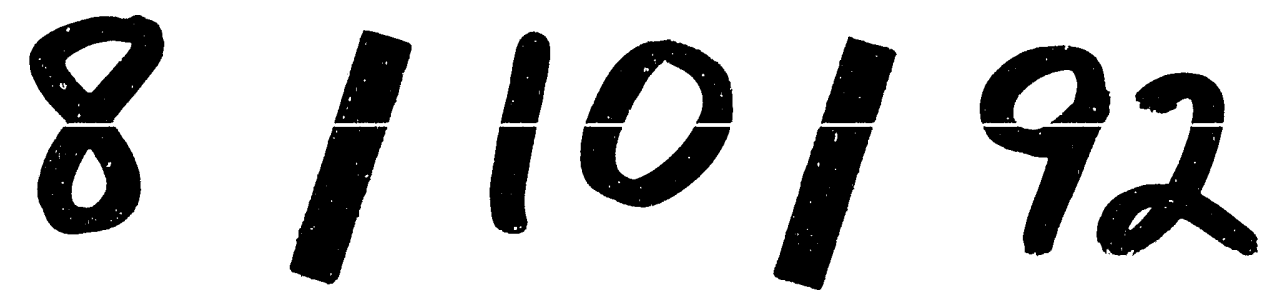


